UNIVERSIDADE DE BRASÍLIA

FACULDADE DE AGRONOMIA E MEDICINA VETERINÁRIA

PROGRAMA DE PÓS-GRADUAÇÃO EM SAÚDE ANIMAL

\title{
SOROPREVALÊNCIA DA HEPATITE E EM SUÍNOS NO DISTRITO FEDERAL, BRASIL.
}

LUCIANA FERREIRA LOBO DE SOUZA VILANOVA

DISSERTAÇÃO DE MESTRADO EM SAÚDE ANIMAL

BRASÍLIA/DF

FEVEREIRO/2016 
UNIVERSIDADE DE BRASÍLIA

FACULDADE DE AGRONOMIA E MEDICINA VETERINÁRIA

PROGRAMA DE PÓS-GRADUAÇÃO EM SAÚDE ANIMAL

\section{SOROPREVALÊNCIA DA HEPATITE E EM SUÍNOS NO DISTRITO FEDERAL, BRASIL.}

LUCIANA FERREIRA LOBO DE SOUZA VILANOVA ORIENTADOR: SIMONE PERECMANIS

DISSERTAÇÃO DE MESTRADO EM SAÚDE ANIMAL PUBLICAÇÃO: DM 125 / 2016 


\section{REFERÊNCIA BIBLIOGRÁFICA E CATALOGAÇÃO}

\section{VILANOVA, L. F. L. S. Soroprevalência da hepatite E em suínos no Distrito Federal,}

Brasil. Brasília: Faculdade de Agronomia e Medicina Veterinária, Universidade de Brasília, 2016, 73p. Dissertação de Mestrado.

Documento formal autorizando reprodução desta dissertação de mestrado para empréstimo ou comercialização exclusivamente para fins acadêmicos. Foi passado pelo autor à Universidade de Brasília e acha-se arquivado na Secretaria do Programa. O autor reserva para si os outros direitos autorais de publicação. Nenhuma parte desta dissertação de mestrado pode ser reproduzida sem a autorização por escrito do autor. Citações são estimuladas desde que citada a fonte.

\section{FICHA CATALOGRÁFICA}

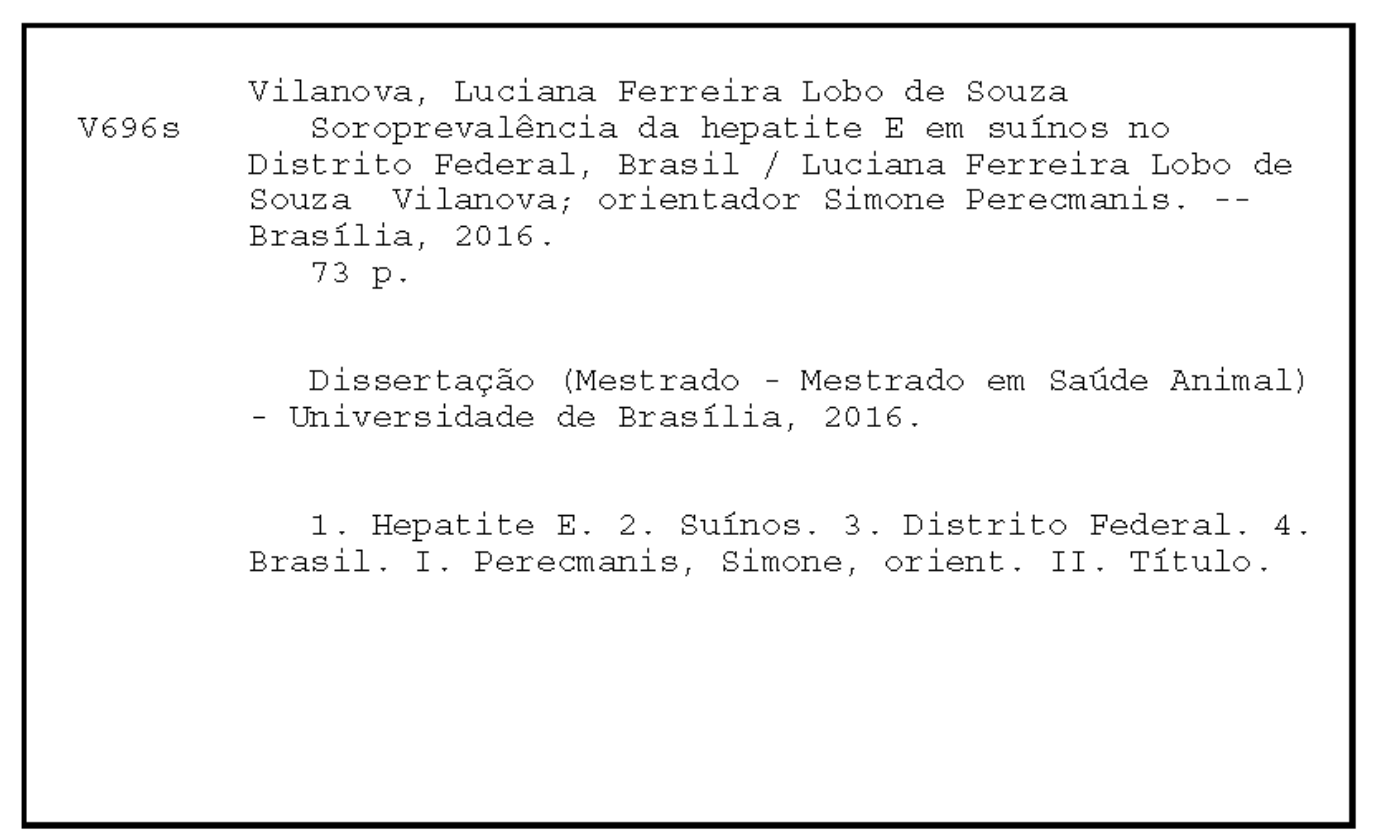


UNIVERSIDADE DE BRASÍLIA

FACULDADE DE AGRONOMIA E MEDICINA VETERINÁRIA

PROGRAMA DE PÓS-GRADUAÇÃO EM SAÚD E ANIMAL

\title{
SOROPREVALÊNCIA DA HEPATITE E EM SUÍNOS NO DISTRITO FEDERAL, BRASIL.
}

\section{LUCIANA FERREIRA LOBO DE SOUZA VILANOVA}

\begin{abstract}
DISSERTAÇÃO DE MESTRADO SUBMETIDA AO PROGRAMA DE PÓSGRADUAÇÃO EM SAÚDE ANIMAL COMO PARTE DOS REQUISITOS NECESSÁRIOS À OBTENÇÃO DO GRAU DE MESTRE EM SAÚDE ANIMAL.
\end{abstract}

APROVADA POR

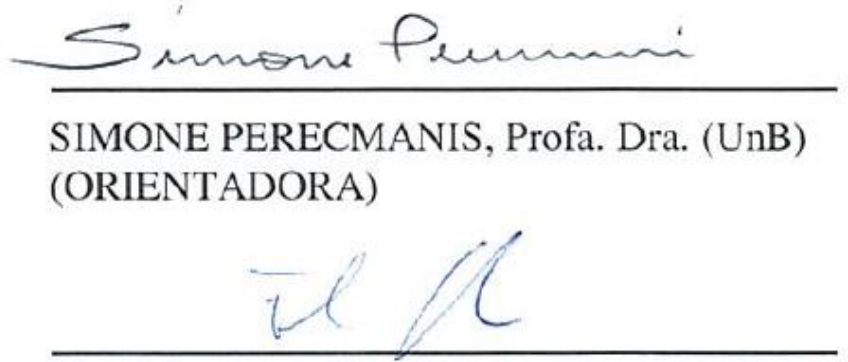

FABIANO JOSÉ FERREIRA DE SANT'ANA, Prof. Dr. (UnB) (EXAMINADOR INTERNO)

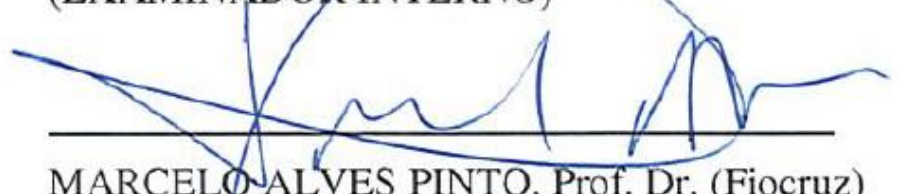

MARCELOALVES PINTO, Prof. Dr. (Fiocruz)

(EXAMINADOR EXTERNO) 


\section{AGRADECIMENTOS}

Agradeço a toda minha família e amigos por todo incentivo e paciência. Ao meu esposo Fernando Vilanova pela presença, mesmo distante, e por toda compreensão, apoio e companheirismo.

À minha orientadora, professora Simone Perecmanis, pelos seus valiosos ensinamentos, amizade e confiança.

Ao Dr. Bruno Dallago pelo suporte técnico-científico mais que essencial.

Aos queridos amigos do Laboratório de Microbiologia Médica Veterinária da Universidade de Brasília, Hudson Holanda, Cléia Nunes e Maurício Macedo, por todo o apoio e amizade.

À Secretaria de Agricultura do Distrito Federal, em especial à médica veterinária Luciana Rigueira, pela valiosa contribuição para a realização desse trabalho.

Aos professores Fabiano José Ferreira Sant'Ana e Marcelo Alves Pinto pela participação na banca examinadora e contribuições para melhoria do trabalho.

À Universidade de Brasília pelo apoio técnico e científico e à CAPES pelo suporte financeiro.

A todos que de alguma maneira contribuíram para a concretização de mais essa etapa em minha vida. 
"Você nem sempre terá o que deseja, mas enquanto estiver ajudando os outros encontrará os recursos de que precisa.”

(André Luiz) 


\section{RESUMO}

A hepatite E é causada pelo vírus da hepatite E (HEV), considerado um patógeno de transmissão zoonótica e que possui suínos como reservatórios. No Brasil, não há informações a respeito da circulação do HEV no rebanho suíno do Distrito Federal. Por isso, foi conduzido um estudo transversal com amostras de soro de 449 suínos domésticos, cedidas pela Secretaria de Agricultura do Distrito Federal. As amostras sanguíneas foram coletadas entre junho e setembro de 2014. Um kit de ELISA comercialmente disponível foi utilizado para a detecção sorológica de anticorpos IgG contra o HEV. Foi encontrada uma alta soroprevalência de anticorpos contra o HEV, uma vez que 304 animais apresentaram amostras reagentes $(67,7 \%$, IC $95 \%=63,2 \%, 71,9 \%)$. A soropositividade não variou com relação ao gênero ou à idade. Os resultados sugerem que o HEV circula entre os suínos domésticos no Distrito Federal, e isso pode servir como um alerta para o sistema de saúde pública da região devido ao possível envolvimento desses animais em infecções humanas.

Palavras-chave: Hepatite E. Suínos. Distrito Federal. Brasil. 


\begin{abstract}
Hepatitis E is caused by hepatitis E virus (HEV) which is currently known to be a zoonotic pathogen and it has pigs as reservoirs. In Brazil, there is no information about the circulation of HEV in swine flocks of the Federal District. Therefore, a cross-sectional study was performed with sera from 449 domestic pigs, provided by the Secretary of Agriculture of the Federal District. Blood samples were collected between June and September 2014. An ELISA kit commercially available was used for the detection of $\mathrm{IgG}$ antibodies. It was found a high seroprevalence of antibodies to $\mathrm{HEV}$, since 304 animals showed anti-HEV positive reactions (67.7\%; $95 \% \mathrm{CI}=63.2 \%, 71.9 \%)$. The seropositivity presented no difference by gender or age. The results suggest that HEV circulates among domestic pigs in the Federal District, and it can serve as a warning to the local public health system about their possible involvement in human infections.
\end{abstract}

Keywords: Hepatitis E. Swine. Federal District. Brazil. 


\section{LISTA DE ILUSTRAÇÕES}

\section{CAPÍTULO II}

Figure 1. Location of the 234 sampled farms, Federal District, Brazil. ................... 44 


\section{LISTA DE TABELAS}

\section{CAPÍTULO I}

Tabela 1. Epidemiologia da infecção do HEV em países considerados hiper-endêmicos e endêmicos. 7

Tabela 2. Características clínicas da infecção do HEV em países considerados hiperendêmicos e endêmicos.

\section{CAPÍTULO II}

Table 1. Frequency of anti-HEV $\operatorname{IgG}$ by gender among pigs of the Federal District,

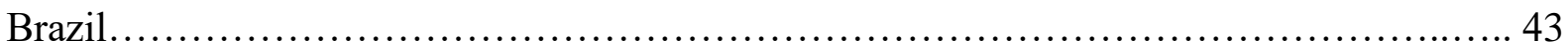

Table 2. Frequency of anti-HEV IgG by age classes among pigs of the Federal District,

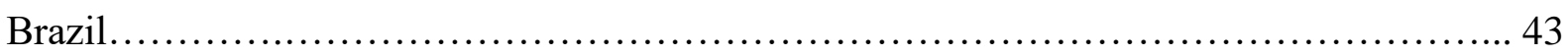

Table 3. Prevalence of anti-HEV IgG in swine sera by regions of the Federal District,

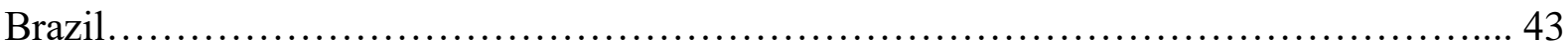




\section{LISTA DE SÍMBOLOS E ABREVIAÇÕES}

ALT - alanina aminotransferase

anti-HEV - contra o vírus da hepatite E

AST - aspartato aminotransferase

ELISA - ensaio imunoenzimático, do inglês enzyme-linked immunosorbent assay

HEV - vírus da hepatite E, do inglês hepatitis E virus.

HEV-1 a 7 - genótipos 1 a 7 do vírus da hepatite $\mathrm{E}$

HIV - vírus da imunodeficiência humana, do inglês human immunodeficiency virus

Hsc70 - proteína do choque térmico conjugada 70

HSP90 - proteína do choque térmico 90

HSPGs - proteoglicanas de sulfato de heparano

IgG - imunoglobulina do tipo $\mathrm{G}$

$\operatorname{IgM}$ - imunoglobulina do tipo $\mathrm{M}$

$\mathrm{kb}$ - quilobase (equivale a 1000 pares de bases), do inglês kilobase

NCRs - regiões não codificantes, do inglês non-coding regions

nm - nanômetros

ORF - região aberta de leitura, do inglês open reading frame

RdRp - RNA-polimerase RNA-dependente

RNA - ácido ribonucleico, do inglês ribonucleic acid

RT-PCR - reação em cadeia da polimerase precedida por transcrição reversa, do inglês reverse transcription polymerase chain reaction

${ }^{\circ} \mathrm{C}$ - graus Celsius 


\section{SUMÁRIO}

CAPÍTULO I

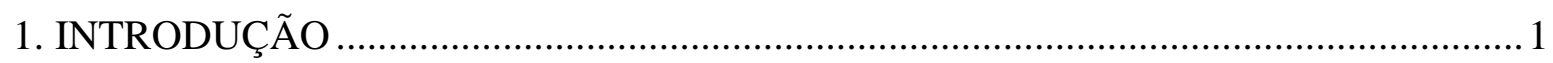

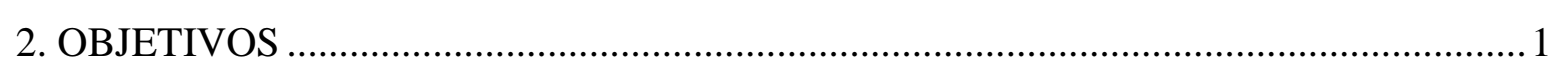

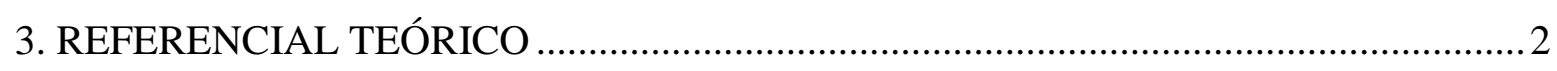

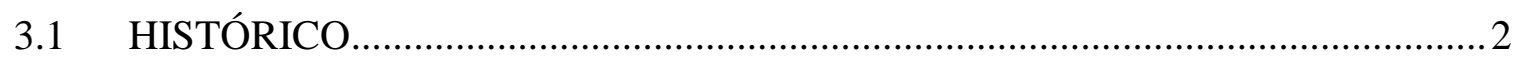

3.2 O VÍRUS DA HEPATITE E (HEV) _........................................................... 2

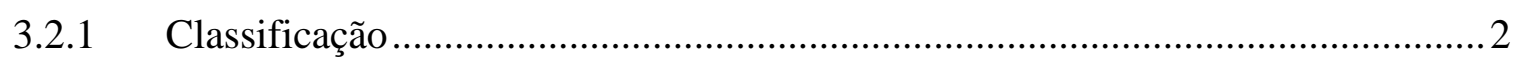

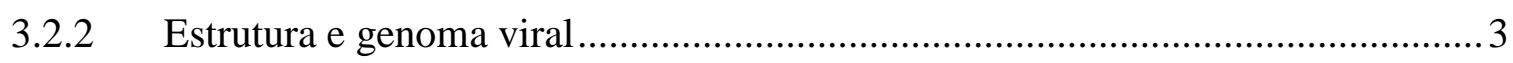

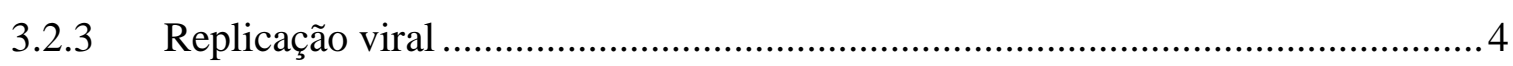

3.2.4 Propriedades …………………………………....................................

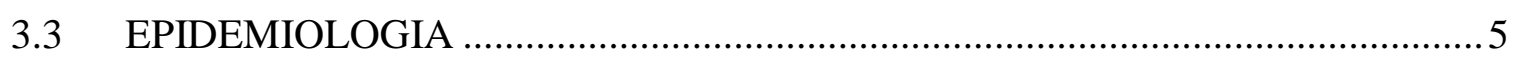

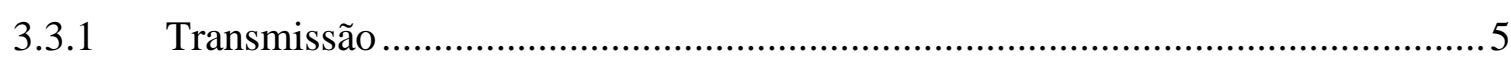

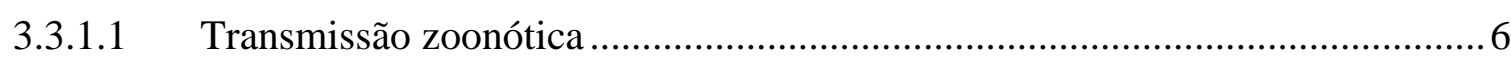

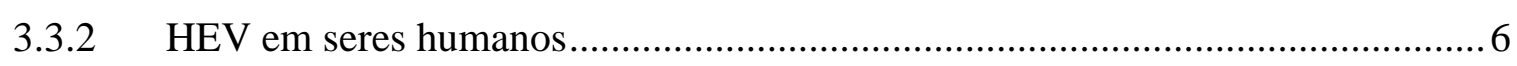

3.3.2.1 HEV em seres humanos no Brasil........................................................... 8

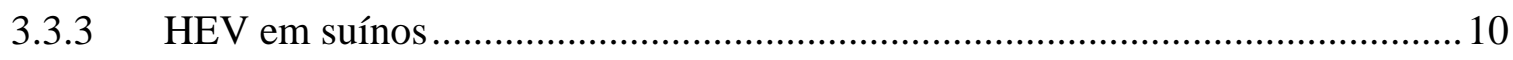

3.3.3.1 HEV em suínos no Brasil ............................................................................ 11

3.3.4 HEV em outras espécies ............................................................................. 12

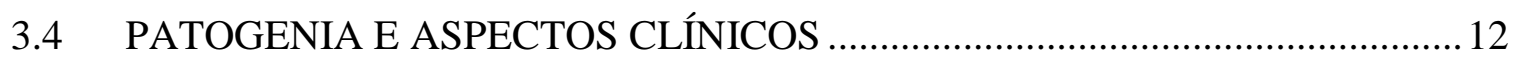

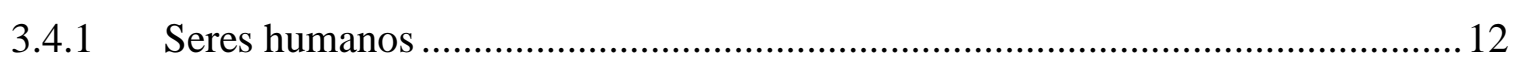

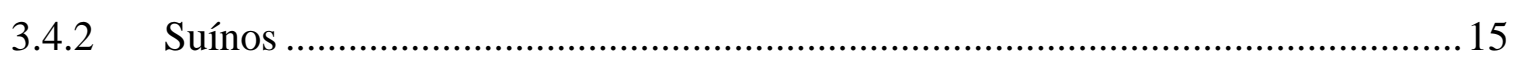

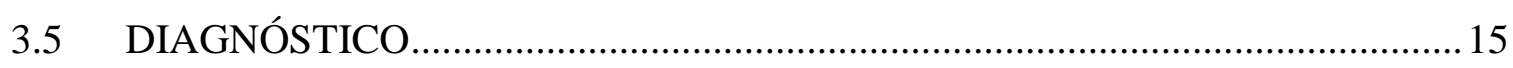

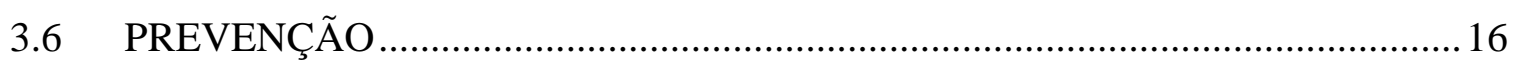

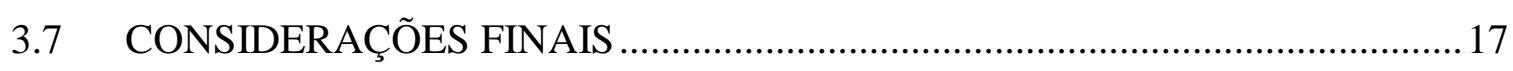

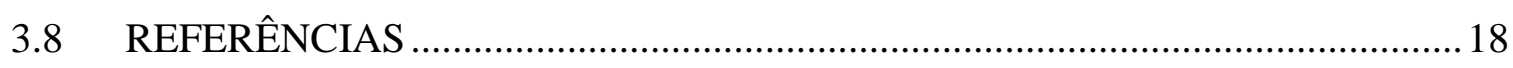

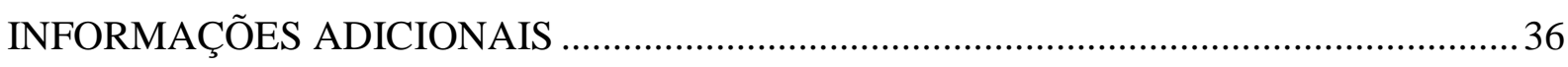

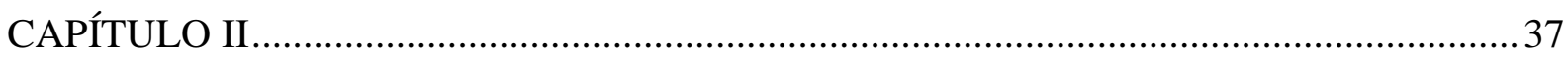

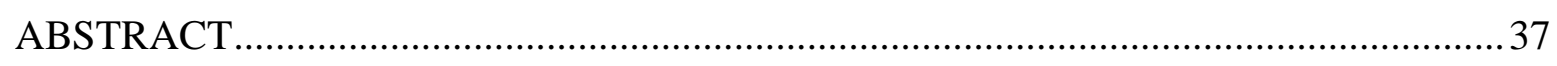

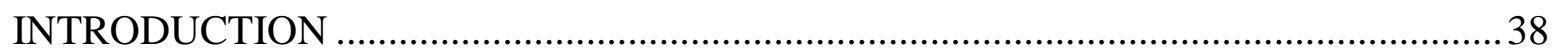

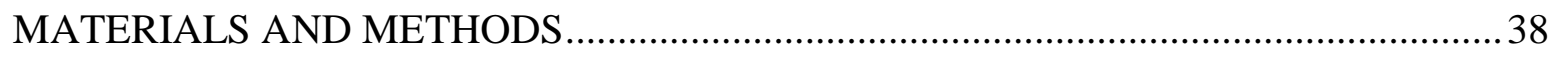

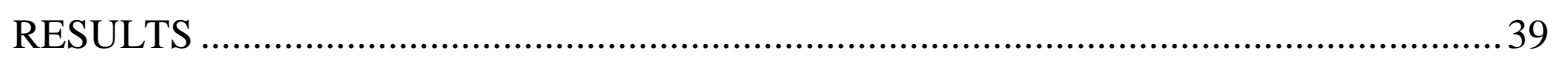




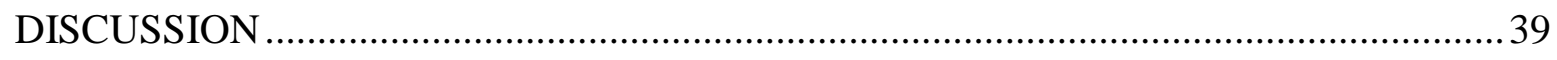

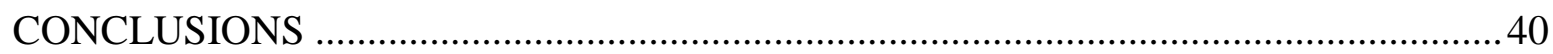

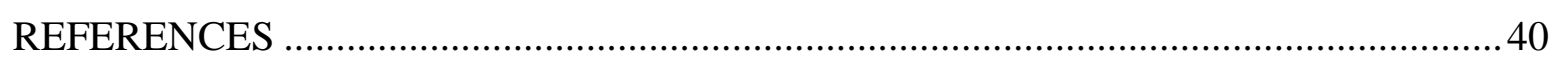

ANEXO A - FORMULÁRIO DE COLHEITA DE AMOSTRAS ….....................................45

ANEXO B - PROTOCOLO DE ELISA PARA DETECÇÃO DE ANTICORPOS ANTI-

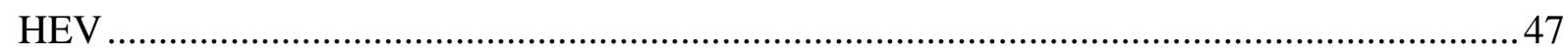

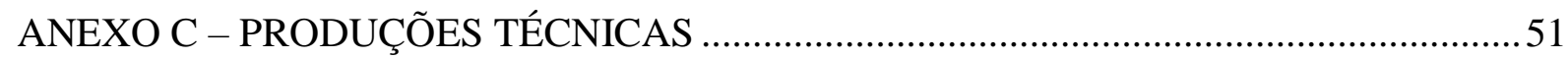




\section{CAPÍTULO I}

\section{INTRODUÇÃO}

A hepatite E é uma hepatite viral reconhecidamente zoonótica, sendo transmitida por suínos e por outros animais, servindo como reservatórios para as infecções humanas (Meng, 2011; Brasil, 2014). Sabe-se que humanos e suínos domésticos compartilham os genótipos 3 e 4 do vírus da hepatite E (HEV) (Smith et al., 2014), os quais circulam em muitos países como o Brasil (Paiva et al., 2007; Lopes dos Santos et al., 2010).

O Ministério da Saúde reconhece que muitos casos humanos podem não estar sendo registrados no país, gerando elevada subnotificação (Brasil, 2012). Além disso, a constatação da circulação do HEV em suínos do rebanho nacional, bem como em outras espécies animais (Guimarães et al., 2005; Vitral et al., 2005; Souza et al., 2012), revela a complexidade epidemiológica da doença, devendo, portanto, ser melhor investigada. No Brasil, não há informações a respeito da circulação do HEV no rebanho suíno do Distrito Federal.

\section{OBJETIVOS}

O presente trabalho teve por objetivo determinar a prevalência de hepatite E em suínos domésticos no Distrito Federal, Brasil.

\subsection{Objetivos específicos:}

- Detectar anticorpos do tipo IgG contra o vírus da hepatite E pelo método de ELISA;

- Estimar a prevalência real da doença;

- Avaliar os resultados com relação à idade e gênero dos animais e à frequência por origem geográfica;

- Avaliar possíveis fatores de risco; e

- Detectar possíveis impactos da enfermidade suína na saúde pública da região. 


\section{REFERENCIAL TEÓRICO}

\subsection{HISTÓRICO}

O vírus da hepatite E (HEV), descoberto em 1983 (Balayan et al., 1983), tem sido desde então associado a grandes surtos de hepatite infecciosa em regiões do mundo onde a contaminação fecal de água para consumo humano é comum, como em países da Ásia e África, sendo considerado endêmico nessas regiões (Murray et al., 2009; Santos et al., 2013; Kamar et al., 2014).

Entretanto, algum tempo após a sua descoberta, percebeu-se que casos esporádicos e autóctones da doença também ocorriam em regiões não endêmicas em pessoas sem histórico de viagens para regiões endêmicas, o que fez aumentar a suspeita de transmissão zoonótica (Zaaijer et al., 1993; Zanetti \& Dawson, 1994; Psichogiou et al., 1995), especialmente após a descoberta do vírus da hepatite E suíno, que possui estreita relação genética com o HEV humano (Meng et al., 1997). Além disso, análises moleculares revelavam que amostras virais provenientes de regiões não endêmicas eram geneticamente diferentes das de regiões endêmicas (Schlauder et al., 1999).

Estudos levantaram assim a hipótese de que os suínos poderiam estar envolvidos na ocorrência dos casos humanos autóctones esporádicos, funcionando como reservatórios da doença (Hsieh et al., 1999; Wu et al., 2000; Pina et al., 2000). Esse aspecto levou ao ressurgimento do interesse mundial da infecção produzida pelo HEV (Aggarwal \& Naik, 2009).

\subsection{O VÍRUS DA HEPATITE E (HEV)}

\subsubsection{Classificação}

O HEV é um vírus de RNA pertencente à família Hepeviridae (Emerson et al., 2004). Análises filogenéticas baseadas no genoma viral e uma série de regiões subgenômicas levaram ao reconhecimento de 4 genótipos principais (genótipos de 1 a 4 ) e 24 subtipos (5 de HEV-1, 2 de HEV-2, 10 de HEV-3 e 7 de HEV-4) (Lu et al., 2006), sendo esta a classificação mais utilizada (Kamar et al., 2014).

A classificação mais recente sugerida por Smith et al. (2014) divide a família Hepeviridae nos gêneros Orthohepevirus (HEV isolados dos mamíferos e das aves) e Piscihepevirus (HEV de trutas). O gênero Orthohepevirus é dividido em A (isolados de 
humanos, suínos, javalis, cervos, mangustos, coelhos e camelos), B (isolados de aves), C (isolados de roedores, musaranhos, furões e visons) e D (isolados de morcegos).

Essa nova classificação ajudaria inclusive a elucidar melhor a questão zoonótica da doença como, por exemplo, no caso do HEV de ratos, uma variante que ainda não foi detectada em humanos e que é claramente distinta de variantes humanas do genótipo 3 do HEV, apesar do HEV-3 já ter sido encontrado infectando ratos (Lack et al., 2012; Smith et al., 2014).

Dentro do grupo Orthohepevirus A, Smith et. al (2014) ainda propõem a classificação de mais três genótipos, HEV-5 e HEV-6 (encontrado em javalis) e HEV-7 (encontrado em camelos), além dos genótipos 1 a 4 que infectam humanos. Os genótipos 1 e 2 circulariam então apenas em humanos, o HEV-3 em humanos, suínos, coelhos, cervos e mangustos e o HEV-4 em humanos e suínos (Smith et al., 2014).

\subsubsection{Estrutura e genoma viral}

O HEV é um vírus não envelopado, esférico, com simetria icosaédrica medindo de 27 a 34nm (Balayan et al., 1983, Bradley et al., 1988). O genoma do vírus possui, aproximadamente, $7,2 \mathrm{~Kb}$ de comprimento (Reyes et al., 1990) e é constituído por uma fita simples de RNA de polaridade positiva com três regiões abertas de leitura (ORFs). Além disso, existem duas regiões não codificantes (NCRs) nas porções terminais 3'e 5' e uma cauda poli-A (Tam et al., 1991).

A ORF1 é a região de leitura mais longa da extremidade 5' do genoma. Codifica as proteínas não estruturais que incluem uma metiltransferase, um domínio Y, uma cisteína protease, uma região rica em prolina, um domínio X, uma helicase e uma RNA-polimerase RNA-dependente (RdRp). Considera-se que a ORF 1 esteja envolvida na replicação viral e no processamento de proteínas virais (Tam et al., 1991; Koonin et al., 1992).

A ORF2 está localizada na extremidade 3' do genoma e codifica a principal proteína do capsídeo viral, responsável pela montagem do virion (Li et al., 1997; Surjit et al., 2004), interação com as células-alvo (He et al., 2008; Kalia et al., 2009) e imunogenicidade (Yarbough et al., 1991; Xing et al., 2011).

A ORF3 sobrepõe parcialmente a ORF2 e codifica uma fosfoproteína envolvida na morfogênese e liberação do virion (Zafrullah et al., 1997; Yamada et al., 2009). Também já foi associada à codificação de um epítopo imunorreativo reconhecido por soros de seres humanos e animais infectados pelo HEV (Yarbough et al., 1991). 


\subsubsection{Replicação viral}

Alguns estudos têm sugerido modelos de replicação para o HEV baseados em outros vírus de RNA de fita positiva (Chandra et al., 2008, Ahmad et al., 2011). Entretanto, devido à indisponibilidade de um eficiente sistema de cultivo celular in vitro pouco se sabe sobre os exatos mecanismos de replicação, transcrição e tradução do vírus (Cao \& Meng, 2012).

Cao e Meng (2012) propuseram um modelo de replicação do vírus baseado em ao menos quatro estudos sobre o assunto. Em resumo, o vírus se adere à superfície da célula-alvo através de proteoglicanas de sulfato de heparano (HSPGs), proteína do choque térmico conjugada 70 (Hsc70) ou outro(s) receptor(es) celular(es) de fixação e, em seguida, entra na célula através de um receptor celular específico desconhecido (Zhou \& Emerson, 2006; Kalia et al., 2009). A proteína do choque térmico 90 (HSP90) e a Grp78, um transportador celular, podem estar envolvidos no transporte do virion para dentro da célula (Zheng et al., 2010; Yu et al., 2011). Ocorre então a descapsidação por mecanismos ainda desconhecidos, liberando o RNA viral no citoplasma da célula. Parte desse material genético é então traduzido para produção da poliproteína não estrutural codificada pela ORF1. Em seguida, a RdRp viral sintetiza a partir do RNA viral um intermediário, o RNA replicativo, de sentido negativo, e que serve como molde para a produção de genoma viral de sentido positivo da progênie. As proteínas da ORF2 e ORF3 são então traduzidas a partir do RNA subgenômico de cadeia positiva. Acredita-se que a proteína do capsídeo da ORF2 empacote o RNA viral e que possui um papel na montagem dos novos virions (Surjit et al., 2004). Em seguida, os novos virions são transportados para a membrana celular. A proteína da ORF3 facilitaria o transporte dos virions, que são posteriormente liberados a partir das células infectadas (Emerson et al., 2010; Nagashima et al., 2011).

Recentemente, Helsen et al. (2016) demostraram com sucesso um novo modelo de replicação para o vírus, baseado em células tronco. Essas células suportaram o ciclo completo de replicação do HEV, demonstrado pela presença de RNA intracelular de cadeia positiva e negativa do HEV e pela produção de virions infecciosos (Helsen et al., 2016).

\subsubsection{Propriedades}

Apesar de o HEV ser sensível em condições experimentais ao calor, cloração e luz ultravioleta, sua sobrevivência no trato intestinal e sua manutenção no ambiente sugerem que o vírus é relativamente estável a condições desfavoráveis como a radiação solar, o dessecamento e a temperaturas e pressões osmóticas variadas (Balayan, 1997; AlbinanaGimenez et al., 2006; Girones et al., 2014). 
Com relação à estabilidade térmica nos alimentos, Emerson et al. (2005) e Feagins et al. (2008) demonstraram que o $\mathrm{HEV}$ permanece infeccioso mesmo após aquecimento a $56^{\circ} \mathrm{C}$ (temperatura de carne mal passada a médio cozimento) durante 1 hora. No entanto, o vírus pode ser completamente inativado pelo cozimento adequado, tal como pela fritura ou fervura da carne durante 5 minutos a uma temperatura interna de $71^{\circ} \mathrm{C}$ (Feagins et al., 2008).

Porém, Barnaud et al. (2012), ao analisarem a infectividade de amostras provenientes de patês preparados com fígado suíno e gordura, além de especiarias, sal de nitrito, dextrose e caseínato de sódio, ou seja, com composição similar a linguiças de fígado de suíno, sugeriram que a efetiva inativação do vírus ocorre somente após 20 minutos durante uma temperatura interna de $71^{\circ} \mathrm{C}$. Segundo esse estudo, a gordura presente nesse tipo de alimento tem um papel protetor, provavelmente contribuindo para a estabilidade do HEV ao calor. Esses achados indicaram assim que a composição alimentar e especialmente a porcentagem de gordura são importantes na determinação da temperatura e tempo de tratamento para inativação do vírus em cada tipo de alimento (Barnaud et al., 2012).

\subsection{EPIDEMIOLOGIA}

\subsubsection{Transmissão}

As rotas de transmissão do vírus mais reladas em seres humanos são: fecal-oral por contaminação de água potável (Khuroo et al., 1980; Balayan et al., 1983), por transmissão vertical (Khuroo et al., 1995) e por transfusões de sangue infectado (Khuroo et. al, 2004; Boxall et al., 2006; Matsubayashi et al., 2008). A transmissão de pessoa a pessoa pode ocorrer, mas é incomum (Teshale et al., 2010b).

Além disso, ocorre também a transmissão pela ingestão de alimentos contaminados, como moluscos (Said et al., 2009; Crossan et al., 2012), e pela ingestão de carne ou órgãos crus ou mal cozidos de animais de caça, como cervos e javalis (Tei et al, 2003; Li et al., 2005), e de suínos (Renou et al., 2014; Pavio et al., 2014).

Assim como ocorre com o ser humano, a via de transmissão do HEV entre suínos é principalmente fecal-oral. Os porcos tornam-se infectados quando o contato direto com outros infectados ocorre ao acaso ou através da ingestão de água ou alimentos contaminados com fezes (Kasorndorkbua et al., 2004). Bouwknegt et al. (2009) já sugeriram uma possível transmissão pela via urinária, ao passo que Hosmillo et al. (2010) também já sugeriram a possibilidade de infecção transplacentária nesses animais. 


\subsubsection{Transmissão zoonótica}

Com relação à transmissão da hepatite E pela ingestão por seres humanos de órgãos ou carne de suínos infectados, na França, diversos estudos têm relacionado a ocorrência de casos autóctones de hepatite $\mathrm{E}$ ao consumo de uma linguiça tradicional feita com fígado suíno, comumente consumida crua, denominada figatellu (Colson et al., 2010; Renou et al., 2014; Pavio et al., 2014). Dois desses estudos chegaram inclusive a demonstrar a presença de partículas virais viáveis do HEV nesse tipo de embutido (Berto et al., 2013; Pavio et al., 2014). Di Bartolo et al. (2015) também identificaram a presença do HEV em diversos tipos de linguiças contendo fígado suíno vendidas em um mercado da Itália, apesar da infectividade do vírus não ter sido demonstrada.

Estudos conduzidos nos Estados Unidos, Japão, Alemanha e Colômbia também já revelaram a presença do HEV suíno em fígados de suínos vendidos em supermercados (Yazaki et. al, 2003; Feagins et. al, 2007; Wenzel et al., 2011; Gutiérrez-Vergara et al., 2015). A carne e o fígado de javali também já foram citados como fonte de transmissão da doença no Japão (Matsuda et al., 2003; Li et al., 2005).

A carne de cervo também tem sido relacionada à ocorrência de casos autóctones de hepatite E. Tei et al. (2003) relataram a transmissão do HEV por meio do consumo de carne mal cozida de cervo no Japão, sugerindo posteriormente que o consumo dessa carne crua ou mal cozida constitui um fator de risco para a doença (Tei et al., 2004).

No Brasil, um caso autóctone de hepatite E no Rio de Janeiro foi associado ao consumo de carne de porco mal cozida alguns meses antes do aparecimento da doença (Lopes dos Santos et al, 2010).

Uma série de estudos em todo mundo têm demonstrado também que populações de seres humanos com exposição ocupacional a suínos têm risco aumentado de transmissão zoonótica do HEV (Drobeniuc et al., 2001; Meng et al., 2002; Bouwknegt et al., 2008; Galiana et. al, 2008; Galiana et. al, 2010; Krumbholz et al., 2012; Lee et al., 2013), apesar de no Brasil, estudo conduzido por Silva et al. (2012) com 310 pessoas expostas a suínos não ter encontrado essa associação.

\subsubsection{HEV em seres humanos}

A infecção humana pelo HEV possui dois padrões epidemiológicos distintos: em regiões com baixas condições de saneamento, por onde circulam principalmente o HEV-1 e HEV-2, resultando em casos esporádicos frequentes e, ocasionalmente, grandes epidemias causadas pelo consumo de água contaminada; e em países mais desenvolvidos, com melhores 
condições de saneamento, por onde circulam principalmente o HEV-3 e HEV-4, resultando em casos esporádicos cujos relatos vêm aumentando durante os últimos anos, relacionados principalmente ao consumo de alimentos contaminados (Teshale et al., 2010c; Kamar et al., 2014) (Tabela 1).

Tabela 1. Epidemiologia da infecção do HEV em países considerados hiper-endêmicos e endêmicos.

\begin{tabular}{|c|c|c|}
\hline Características & HEV em regiões hiper-endêmicas & HEV em regiões endêmicas \\
\hline Genótipos & 1 e 2 & 3 e 4 \\
\hline Fontes & Seres humanos & Animais e seres humanos \\
\hline Transmissão & Fecal-oral por água contaminada & $\begin{array}{l}\text { Fecal-oral por exposição direta, } \\
\text { água contaminada e consumo de } \\
\text { carne crua ou mal passada. }\end{array}$ \\
\hline $\begin{array}{l}\text { Infecção por transfusão } \\
\text { sanguínea }\end{array}$ & Sim & Sim \\
\hline Prevalência & Maior entre homens jovens / adultos. & $\begin{array}{l}\text { Maior entre homens adultos / } \\
\text { idosos. }\end{array}$ \\
\hline Surtos & $\begin{array}{l}\text { Sim, pode envolver milhares de } \\
\text { casos. }\end{array}$ & Não \\
\hline Sazonalidade & $\begin{array}{c}\text { Sim, surtos ocorrem na época das } \\
\text { chuvas. }\end{array}$ & Não \\
\hline Mortalidade em grávidas & Sim, em torno de $20 \%$. & Não \\
\hline
\end{tabular}

Fonte: adaptado de Kamar et al. (2014).

O HEV-1 foi identificado circulando principalmente na Ásia e na África em países como Índia (Arankalle et al., 1999), Sudão (Nicand et al., 2005), Uganda (Teshale et al., 2010a), Paquistão (Iqbal et al., 2011), China (Liu et al., 2012) e Nepal (Shrestha et al., 2015). Há relatos também de sua detecção em Cuba (Villalba et al., 2008), na Itália (La Rosa et al., 2010), na Venezuela (García et al., 2012) e no Uruguai (Mirazo et al., 2014).

O HEV-2 foi identificado no México (Huang et al., 1992) e na África (Buisson et al., 2000; Maila et al., 2004).

Já o HEV-3 possui distribuição mundial e já foi descrito na América da Norte em países como Estados Unidos (Tohme et al., 2011); na América do Sul, no Brasil (Lopes dos Santos et al., 2010), na Bolívia (Dell’Amico et al., 2011), Venezuela (García et al., 2012), Uruguai (Mirazo et al., 2013) e Argentina (Munné et al., 2014); na América Central em Cuba (Villalba et al., 2013); na Europa em países como a França (Mansuy et al., 2004), Reino Unido (Banks et al., 2004), Holanda (Borgen et al., 2008), Hungria (Reuter et al., 2009), Itália (La Rosa et al., 2010) e Eslovênia (Steyer et al., 2011); em países asiáticos como Japão 
(Mizuo et al., 2002), Tailândia (Suwannakarn et al., 2010), China (Liu et al., 2012) e Filipinas (Li et al., 2014); e em países africanos como o Egito (Kamel et al., 2011).

Por fim, o HEV-4 inclui isolados que já foram identificados na Ásia em países como Japão (Mizuo et al., 2002), Índia (Rolfe et al., 2010), China (Liu et al., 2012) e Camboja (Yamada et al., 2015); e na Europa, na França (Tessé et al., 2012), Itália (Garbuglia et al., 2013) e Dinamarca (Midgley et al., 2014).

É interessante notar que países como França, Itália, Uruguai, Venezuela, Cuba, China, Índia e Japão relataram a detecção de mais um genótipo em seu país, revelando assim a complexidade epidemiológica do vírus.

Com relação aos estudos de prevalência, anticorpos anti-HEV podem ser encontrados em pessoas aparentemente saudáveis em todo o mundo. No continente africano, a soroprevalência varia consideravelmente entre $0 \%$ e 84,3\% (Kim et al., 2014). Na Europa, durante a última década, a soroprevalência de IgG anti-HEV tem aumentado e apresentado uma variação significativa entre os diferentes países, entre 1\% e 52\% (Lapa et al., 2015). O mesmo acontece na Ásia, onde a soroprevalência parece variar entre 5,9\% e 46,1\% (Yoon et al., 2014; Farshadpour et al., 2015), e no continente americano, onde a prevalência encontrada de anticorpos contra o HEV varia entre $0 \%$ e 36,3\% (Echevarría et al., 2013; AlvaradoEsquivel et al., 2014).

Considera-se que a mortalidade causada pela hepatite $\mathrm{E}$ varie em torno de 1\% (Santos et al., 2013; Pérez-Gracia et al., 2015). Porém, estudos têm demonstrado a gravidade da doença em grávidas e indivíduos com doença hepática pré-existente que desenvolvem a infecção pelo HEV. A taxa de mortalidade em grávidas varia em torno de $20 \%$, normalmente acontecendo no terceiro trimestre (Khuroo et al., 1981; Kumar et al., 2004; Khaskheli et al., 2015), tendo sua ocorrência relacionada especialmente ao genótipo 1 do vírus (Teo, 2012). A mortalidade também é considerada mais alta para indivíduos com doença hepática préexistente (Ramachandran et al., 2004; Kumar et al., 2007).

Por fim, estima-se que os genótipos 1 e 2 do HEV ocasionem anualmente cerca de 20 milhões de infecções, 3,4 milhões de casos assintomáticos, levando à, aproximadamente, 70 mil mortes e 3000 natimortos (Rein et al., 2012).

\subsubsection{HEV em seres humanos no Brasil}

No Brasil, a hepatite E é uma doença de notificação obrigatória (Brasil, 2005). Surtos da doença nunca foram relatados, apesar de as condições ambientais e de saneamento de algumas regiões favorecerem a sua transmissão (Brasil, 2014). 
Dados do Ministério da Saúde revelam que entre 1999 e 2011 foram registrados 967 casos confirmados de hepatite E no Brasil, sendo 470 casos na região Sudeste (48,6\%), 173 no Nordeste (17,9\%), 130 no Sul (13, 4\%), 106 no Norte (11\%) e 88 no Centro Oeste $(9,1 \%)$. Além disso, entre 2000 e 2011, foram declarados 86 óbitos por hepatite E no país, a maioria dos quais na região Sudeste $(58,1 \%)$ (Brasil, 2012).

Em Salvador, na Bahia, Paraná et al. (1997) relataram uma frequência de 17,7\% de pacientes com hepatite viral aguda portando anticorpos anti-HEV (IgG). Anticorpos também foram detectados em 2\% de doadores de sangue. Em Campinas, no estado de São Paulo, valor semelhante foi encontrado em doadores de sangue (3\%) e a prevalência em outros grupos de pessoas variou entre $2,6 \%$ a $17,7 \%$ (Gonçales et. al, 2000).

No Rio de Janeiro, Trinta et al. (2001) relataram soropositividade (IgG) de 2,1\% em pacientes com hepatite viral aguda, 6,2\% em pacientes de hemodiálise, 4,3\% em doadores de sangue, $11,8 \%$ em usuários de drogas injetáveis, $1 \%$ em mulheres grávidas e 2,1\% em indivíduos de zonas rurais. No mesmo estado, baixa soropositividade $(2,4 \%)$, pesquisada em 669 indivíduos, também foi encontrada por Santos et al. (2002).

No Mato Grosso, estudo realizado com crianças menores de 10 anos revelou uma frequência de 4,5\% de anticorpos IgG anti-HEV (Assis et al., 2002).

Em estudo posterior conduzido na Bahia, Lyra et al. (2005) encontraram evidências de uma co-infecção de HEV com o vírus da hepatite A, além de detectarem anticorpos anti-HEV do tipo IgM em 5 pacientes, revelando infecções recentes. No ano seguinte, Bortoliero et al. (2006) relataram baixa prevalência de IgG anti-HEV (2,3\%) em doadores de sangue de Londrina, no Paraná.

No Acre, anticorpos anti-HEV (IgG) foram encontrados em 12,9\% da população estudada e anticorpos do tipo IgM em 16,3\% das amostras positivas, demonstrando infecção recente (Vitral et al., 2014). Em Goiás, Martins et al. (2014) encontraram IgG anti-HEV em 5,1\% e IgM em 0,7\% de 431 catadores de lixo da cidade de Goiânia. Já em São Paulo, o levantamento de dados de um laboratório clínico revelou uma frequência de 2,1\% de testes positivos para IgG anti-HEV (Passos-Castilho et al., 2015).

Apesar de o Brasil estar localizado em uma região considerada de baixa endemicidade humana para HEV, muitos estudos de soroprevalência estão desatualizados e não podem ser devidamente comparados devido ao uso de diferentes metodologias (Khudyakov \& Kamili, 2011; Echevarría et al., 2013). Além disso, o HEV não é rotineiramente investigado no Brasil, mesmo em casos de elevação de enzimas hepáticas sem explicação ou hepatite aguda, e poucos laboratórios realizam testes para diagnóstico da doença (Passos-Castilho et al., 2015). 
Além disso, a falta de um estudo epidemiológico de âmbito nacional a respeito da doença dificulta o conhecimento sobre sua real situação no país. O Ministério da Saúde reconhece que muitos casos podem não estar sendo registrados no país, gerando elevada subnotificação em razão do amplo espectro da doença e da proporção considerável de casos assintomáticos que permanecem desconhecidos do sistema de vigilância (Brasil, 2012).

\subsubsection{HEV em suínos}

A infecção suína causada pelos genótipos 3 e 4 do HEV é generalizada em todo o mundo, ocorrendo geralmente entre os 2 a 3 meses de idade devido à falta de anticorpos maternos (Meng et. al, 1997; de Deus et al., 2008).

O genótipo 3 suíno parece ser mais disseminado e já foi identificado em países europeus como Reino Unido (Banks et al., 2004), Espanha (de Deus et al., 2008), Hungria (Forgách et al., 2010), Alemanha (Wenzel et al., 2011), França (Rose et al., 2011), Itália (Di Bartolo et al., 2011), Eslovênia (Steyer et al., 2011), Romênia (Aniţă et al., 2014) e Estônia (Ivanova et al., 2015); no continente americano no México (Cooper et al., 2005), Argentina (Munné et al., 2006), Costa Rica (Kase et al., 2008), Bolívia (Dell'Amico et al., 2011), Colômbia (Gutiérrez-Vergara et al., 2015) e Brasil (Paiva et al., 2007; dos Santos et al., 2009; dos Santos et al., 2011; Gardinali et al., 2012; Vasconcelos et al., 2015); em países da Ásia como Tailândia (Cooper et al., 2005), Coréia do Sul (Hosmillo et al., 2010), Japão (Ishida et al., 2012) e Filipinas (Liu et al., 2015); e na África, em Camarões (de Paula et al., 2013).

O genótipo 4, por outro lado, parece estar restrito a países asiáticos como a Índia (Arankalle et al., 2002), o Japão (Ishida et al., 2012) e a China (Shu et al., 2014) e a países europeus como a Bélgica (Hakze-van der Honing et al., 2011) e a Itália (Monne et al., 2015).

Com relação aos dados sorológicos nesses animais, há uma série de estudos que relataram a detecção de anticorpos anti-HEV do tipo IgG em suínos de todo o mundo. A soroprevalência em suínos encontrada em países europeus varia consideravelmente entre $27 \%$ e 92,8\% (O’Connor et al., 2015; Grierson et al., 2015). Em países asiáticos, entre 14,8\% e 64,7\% (Choi et al., 2003; Liang et al., 2014a). No continente americano, entre 22,7\% e 80\% (Munné et al., 2006; Cooper et al., 2005).

Já na Oceania, estudos conduzidos na Nova Zelândia demonstraram a circulação do vírus em suínos por meio de estudos de soroprevalência de rebanho e de RNA viral em fezes. Vinte dos vinte e dois rebanhos testados (91\%) possuíam anticorpos anti-HEV. É interessante notar que um dos rebanhos negativos era proveniente das Ilhas Auckland, que continha uma 
população de suínos sem contato com outros suínos há aproximadamente 200 anos (Garkavenko et al., 2001).

\subsubsection{HEV em suínos no Brasil}

No Brasil, o RNA viral do genótipo 3 suíno já foi identificado por RT-PCR em amostras de fezes em São Paulo (Paiva et al., 2007), Rio de Janeiro (dos Santos et. al, 2009; dos Santos et al., 2011), Pará (Souza et al., 2012) e Rio Grande do Sul (Vasconcelos et al., 2015); em amostras de bile no Rio de Janeiro (dos Santos et al., 2011) e no Paraná (Gardinali et al., 2012); e em amostras de fígado no Pará (Souza et al., 2012) e no Paraná (Gardinali et al., 2012).

O HEV-3 também já foi identificado na água de esgoto de matadouros de suínos e era geneticamente relacionado ao primeiro isolado humano descrito no Brasil (Lopes dos Santos et al., 2010) e a dois isolados suínos caracterizados anteriormente (dos Santos et al., 2009) (dos Santos et al., 2011).

No Rio Grande do Sul, em estudo mais recente, $100 \%$ das amostras de lagoas de chorume foram positivas para o RNA do HEV (Vasconcelos et al., 2015). Assim, as fezes de suínos poderiam estar servindo como fonte de contaminação da água potável e de irrigação, levando à transmissão potencial do HEV para os seres humanos (Vasconcelos et al., 2015), já que frequentemente esses dejetos são utilizados como fertilizantes (Cardoso et al., 2015).

A presença de RNA do HEV em fontes de água como rios e até água do mar também já foi detectada em estudos conduzidos na Eslovênia (Steyer et al., 2011), no Japão (Ishida et al., 2012) e nos Estados Unidos (Gentry-Shields et al., 2015), apesar de a viabilidade e infectividade do vírus não terem sido confirmadas.

Infelizmente, no Brasil, os estudos sorológicos ainda são escassos. Levantamento realizado com 260 animais provenientes de 13 diferentes municípios do estado de Mato Grosso revelou uma prevalência de IgG anti-HEV de 81,2\%, demonstrando a circulação do HEV em suínos deste estado (Guimarães et al, 2005). No Rio de janeiro, Vitral et al. (2005) também detectaram uma alta prevalência de anticorpos anti-HEV ao analisarem 357 amostras de soro de suínos $(63,6 \%)$. Já no Pará, somente 13 das 151 amostras de soro suíno $(8,6 \%)$ foram positivas para IgG anti-HEV (Souza et al., 2012).

Essa ampla variação na prevalência de anticorpos suínos contra o HEV pode ser explicada também devido a diferentes níveis de sensibilidade e especificidade dos testes sorológicos utilizados (Khudyakov \& Kamili, 2011). Além disso, estudos têm demonstrado 
que a prevalência do HEV suíno está estreitamente associada a diferenças no manejo e na higiene das instalações de criação (Casas et al., 2011; Walachowski et al., 2014).

\subsubsection{HEV em outras espécies}

Apesar de os humanos compartilharem os genótipos 3 e 4, até o momento, apenas com determinados animais (suínos, coelhos, cervos e mangustos), estudos revelaram que o vírus é capaz de atravessar a barreira entre espécies. Perus já foram experimentalmente infectados com amostras de HEV isoladas de frangos (Sun et al., 2004); suínos já foram infectados com HEV de javalis (Schlosser et al., 2014); primatas já foram infectados com HEV suíno (Meng et al., 1998; de Carvalho et al., 2013) e humano (de Carvalho et al., 2013); enquanto suínos, cordeiros e ratos já foram infectados experimentalmente com HEV humano (Usmanov et al., 1994; Maneerat et al., 1996; Meng et al., 1998; Halbur et al., 2001).

Em diversos países do mundo, a detecção de anticorpos anti-HEV tem sido descrita em outras espécies de animais como roedores (Favorov et al., 2000; Arankalle et al, 2001), bovinos (Arankalle et al, 2001), caninos (Arankalle et al, 2001; Liang et al., 2014b), aves (Sun et al., 2004), cervos (Sonoda et al., 2004; Lin et al., 2015), javalis (Sonoda et al., 2004; Larska et al., 2015), mangustos (Nakamura et al., 2006), equinos (Saad et al, 2007), felinos (Peralta et al., 2009; Liang et al., 2014b), caprinos (Peralta et al., 2009), ovinos (Peralta et al., 2009; Wu et al., 2015) e coelhos (Geng et al., 2011). Toda esta informação sorológica aponta que determinadas espécies são expostas ao HEV (ou agente semelhantes ao HEV), embora a epidemiologia da infecção ainda permaneça obscura em muitos casos (Pérez-Gracia et al., 2015).

No Brasil, estudo conduzido no estado do Rio de Janeiro, revelou a presença de anticorpos anti-HEV em bovinos, cães, galinhas, suínos e roedores silvestres (Vitral et al., 2005).

Evidências da circulação do HEV por meio da detecção de RNA viral em amostras fecais também já foram encontradas em camelos (Woo et al., 2014), furões domésticos (Li et al., 2015) e outros mamíferos silvestres (Lhomme et al., 2015).

\subsection{PATOGENIA E ASPECTOS CLÍNICOS}

\subsubsection{Seres humanos}

A patogênese da infecção pelo HEV ainda não é bem compreendida, especialmente quando se trata de suas formas mais graves (Panda \& Varma, 2013). Os dados que se têm são derivados de raros estudos com voluntários, pesquisas com pacientes afetados por surtos da 
doença e modelos experimentais de infecção em primatas não humanos (Krawczynski et al., 2011; Panda \& Varma, 2013).

Sabe-se que o vírus da hepatite E é transmitido pela via oral e, embora o sítio de replicação primária não tenha sido determinado, supõe-se que seja o trato intestinal (Panda \& Varma, 2013). O vírus chega então ao fígado, provavelmente pela veia porta, replica-se em hepatócitos e é liberado nas fezes pela bile (Lau et al., 1995; Kawai et al., 1999) e no sangue por mecanismos desconhecidos (Panda \& Varma, 2013). Há evidências também da ocorrência de replicação viral na placenta (Bose et al., 2014).

Estudos clínicos em que voluntários ingeriram preparações derivadas de amostras fecais de pacientes com suspeita de hepatite E verificaram o aparecimento dos primeiros sintomas entre 30 a 36 dias após inoculação. As alterações clínicas mais comuns observadas foram dor abdominal, náusea, vômito, anorexia, seguidos por febre, hemoglobinúria, hepatomegalia e, posteriormente, icterícia, além do aumento das enzimas hepáticas ALT e AST (Balayan et al., 1983; Chauhan et al., 1993).

Esses voluntários se recuperaram completamente somente entre 60 (Balayan et al., 1983) e 120 dias pós-inoculação (Chauhan et al., 1993). Já Aggarwal et al. (2000), ao avaliarem 20 pacientes com hepatite E aguda naturalmente infectados, observaram uma duração menor dos sintomas, entre 4 e 19 dias (média de 9 dias).

Os sintomas observados em voluntários se assemelham bastante aos relatos de hepatite aguda associados a epidemias e casos esporádicos da doença. Porém, além de uma infecção aguda e autolimitada, pode ser observada também a ocorrência de infecções inaparentes ou assintomáticas até a falência hepática fulminante (Aggarwal, 2011) (Tabela 2).

Tabela 2. Características clínicas da infecção do HEV em países considerados hiper-endêmicos e endêmicos.

\begin{tabular}{|c|c|c|}
\hline Características & HEV em regiões hiper-endêmicas & HEV em regiões endêmicas \\
\hline Curso clínico & $\begin{array}{c}\text { Infecção aguda auto-limitada na } \\
\text { maioria }\end{array}$ & $\begin{array}{c}\text { Infecção aguda auto-limitada } \\
\text { na maioria }\end{array}$ \\
\hline $\begin{array}{l}\text { Prognóstico em } \\
\text { pacientes com doença } \\
\text { hepática pré-existente }\end{array}$ & Ruim & Ruim \\
\hline Prognóstico em grávidas & Ruim & Sem relação \\
\hline Infecção crônica & Não & Sim \\
\hline
\end{tabular}

Fonte: adaptado de Kamar et al., 2014. 
A falência hepática fulminante tem sido mais observada em mulheres grávidas e indivíduos com doença hepática pré-existente (Khuroo et al., 1981; Kumar et al., 2004; Kumar et al., 2007; Khaskheli et al., 2015). A hepatite E durante a gravidez também é associada ao nascimento de prematuros, ao baixo peso ao nascimento e ao risco aumentado de mortalidade perinatal (Patra et al., 2007).

Em pacientes com hepatite aguda grave as alterações microscópicas hepáticas incluem necrose, inflamação linfocítica e de polimorfonucleares e colangite aguda com numerosos neutrófilos (Malcolm et al., 2007).

Para a hepatite clássica aguda, considera-se que o período de incubação possa variar entre 2 e 9 semanas e o de transmissibilidade entre 2 semanas antes do início dos sintomas até 4 a 6 semanas após o início dos sintomas (Chauhan et al., 1993; Aggarwal et al., 2000; Takahashi et al., 2007; Dalton et al., 2008; Chandra et al., 2010).

A IgG está presente na fase de convalescença e pode persistir por tempo indeterminado (Khuroo et al., 1993). Já a IgM surge de 4 a 5 dias após início dos sintomas, desaparecendo de 4 a 5 meses depois (Favorov et al., 1992).

Além da hepatite aguda, infecções persistentes são associadas à hepatite crônica em pacientes imunossuprimidos, como aqueles que apresentam infecção pelo HIV e especialmente em transplantados de fígado, pâncreas e rim. Esses indivíduos apresentam fibrose hepática progressiva que culmina em cirrose (Kamar et al., 2008; Gérolami et al., 2008; Dalton et al., 2009).

A infecção crônica pelo HEV é definida pela presença de níveis elevados das enzimas hepáticas e pela evidência do RNA viral no soro e/ou nas fezes por pelo menos seis meses. Imunossupressão e baixas contagens de linfócitos e plaquetas são considerados fatores de risco para a essa cronicidade (Kamar et al., 2011).

Em 2013, foi feito o primeiro relato da infecção por hepatite E em transplantados renais no Brasil. O estudo analisou o soro de 96 pacientes que receberam transplante de rins e que demonstraram aumento inexplicável de enzimas hepáticas. O RNA viral foi encontrado nas amostras de três pacientes (Passos et al., 2013).

Diversas manifestações extra-hepáticas já foram descritas em pacientes com infecção pelo HEV. Pancreatite aguda, distúrbios neurológicos, anemia hemolítica, trombocitopenia grave e glomerulonefrite são as mais frequentes (Bazerbachi et al., 2015).

Entre os genótipos 3 e 4, o genótipo 4 seria responsável por manifestações clínicas mais severas (Ohnishi et al., 2006). 


\subsubsection{Suínos}

Nos suínos não são observadas manifestações clínicas sugerindo que a infecção é, em sua maioria, assintomática, apesar de aumento moderado de linfonodos mesentéricos e evidências microscópicas de hepatite, incluindo necrose e inflamação linfoplasmocítica multifocal e periportal, terem sido observados em suínos infectados experimentalmente e naturalmente (Meng et al., 1997; Halbur et al., 2001; de Deus et al., 2008; dos Santos et al., 2009; Bouwknegt et al., 2009). Aumento nos níveis de enzimas hepáticas no soro geralmente não é observado (Halbur et al., 2001; Bouwknegt et al., 2009).

Animais inoculados experimentalmente com um isolado humano americano apresentaram lesões hepáticas mais severas e persistentes quando comparados àqueles que foram infectados com isolado suíno, em que as lesões hepáticas se resolveram quase que completamente dentro de, aproximadamente, 60 dias (Halbur et al., 2001).

O RNA do vírus da hepatite E já foi encontrado, além do fígado, no intestino, linfonodos, baço, rins, bexiga, urina e músculos desses animais (Williams et al., 2001; Choi \& Chae, 2003; Bouwknegt et al., 2009; Leblanc et al., 2010).

Em suínos infectados naturalmente, os anticorpos maternos do tipo IgG perduram até aproximadamente 9 semanas de idade (Meng et al., 1997; de Deus et al., 2008). Há relatos de sua duração até 16 semanas de idade (dos Santos et al., 2009). A partir daí os porcos tornamse infectados, passando a ser possível a detecção de $\operatorname{IgM}$, que pode durar entre 5 e 7 semanas (de Deus et al., 2008).

A soroconversão parece ocorrer entre a $15^{\circ}$ e a $22^{\mathrm{a}}$ semana de idade (Meng et al., 1997; de Deus et al., 2008; dos Santos et al., 2009).

\subsection{DIAGNÓSTICO}

Os sinais clínicos observados em seres humanos, assim como a ausência de sintomas observada tanto em humanos quanto nos suínos, não permitem a diferenciação da hepatite $\mathrm{E}$ das outras hepatites virais agudas, sendo necessário recorrer ao diagnóstico laboratorial.

O diagnóstico laboratorial inclui testes sorológicos, principalmente do tipo ELISA, para pesquisa de anticorpos das classes IgM e IgG específicos para o HEV. Testes baseados em imunocromatografia e western blot também já foram desenvolvidos para fins de diagnóstico (Khudyakov \& Kamili, 2011).

Kits comerciais de ELISA para detecção de anticorpos contra os quatro principais genótipos do HEV já foram desenvolvidos e são baseados principalmente na detecção de anticorpos contra antígenos da ORF2 e ORF3 do HEV. Entretanto, esses kits costumam variar 
com relação à sensibilidade e à especificidade (Mast et al., 1998; Khudyakov \& Kamili et al., 2011). Sendo assim, na ausência de um teste diagnóstico universal confiável, muitos casos continuam não sendo diagnosticados.

A variação observada na sensibilidade e especificidade dos testes sorológicos disponíveis pode ser explicada pela diferença significativa de marcadores sorológicos de infecções agudas, recentes ou passadas em conjunto com a cinética variável de anticorpos exibidos por indivíduos infectados, demonstrando a complexidade da resposta imune ao HEV. Esta complexidade é, além disso, agravada pela heterogeneidade do genoma do vírus e a estrutura antigênica diversa das proteínas do HEV (Khudyakov \& Kamili, 2011).

Para contornar esse problema as técnicas moleculares, especialmente o RT-PCR, têm sido utilizadas na detecção do RNA viral no sangue e nas fezes de seres humanos (Krawczynski et al., 2011), sendo extremamente útil no diagnóstico da doença em indivíduos imunocomprometidos (Kamar et al., 2014). A detecção nas fezes se dá 1 semana antes e até 6 semanas após o início dos sintomas, e no soro ocorre durante 3 a 6 semanas após o início dos sintomas (Aggarwal et al., 2000; Takahashi et al., 2007; Chandra et al., 2010).

A detecção de RNA do HEV também é crucial para o monitoramento da infecção crônica após imunossupressão e para a caracterização genotípica (Kamar et al., 2014).

Em suínos, o RNA viral tem sido detectado principalmente no sangue, fezes, bile, fígado e linfonodos (de Deus et al., 2007; Leblanc et al., 2010; Souza et al., 2012). A detecção em linfonodos mesentéricos, sangue e fezes ocorre principalmente a partir de 9 semanas de idade, e no fígado e na bile, a partir de 12 semanas (de Deus et al., 2008).

Em seres humanos, como diagnóstico diferencial podem ser citadas doenças como: leptospirose, febre amarela, malária, dengue hemorrágica, além de outras hepatites como hepatite alcoólica, hepatite medicamentosa, hepatite autoimune, hepatites reacionais ou transinfecciosas (acompanham infecções gerais, como sepse), icterícias hemolíticas (como anemia falciforme) e colestase extra-hepática por obstrução mecânica das vias biliares (tumores, cálculo de vias biliares, adenomegalias abdominais) (Brasil, 2014).

Halbur et al. (2001) sugerem que a infecção suína pelo HEV deve considerar como diagnóstico diferencial para hepatites virais a síndrome reprodutiva respiratória, circovírus e o vírus pseudorábico.

\subsection{PREVENÇÃO}

Nos países onde a principal forma de transmissão é a fecal-oral, a melhor forma de se evitar a doença é melhorando as condições de higiene e de saneamento básico, como, por 
exemplo, lavar as mãos após ir ao banheiro e antes de comer ou preparar alimentos; lavar bem os alimentos que são consumidos crus; não tomar banho ou brincar perto de valões, riachos, chafarizes, enchentes ou próximo de onde haja esgoto a céu aberto; evitar a construção de fossas próximas a poços e nascentes de rios para não comprometer o lençol d'água que alimenta o poço; entre outros (Brasil, 2005).

Já naqueles países onde a transmissão zoonótica é mais importante, como é o caso do Brasil, deve-se evitar consumir carne crua ou mal passada de qualquer animal, não somente de suínos, cervos e coelhos (os quais compartilham os mesmos genótipos do HEV com seres humanos), já que o vírus parece circular em várias espécies animais. Indivíduos que estão expostos aos suínos devem utilizar equipamentos de proteção individual e tomar medidas de higiene após lidar com esses animais.

Com relação a outras populações em risco como indivíduos com doença hepática prévia e imunossuprimidos devem ser informados sobre o risco de se consumir carne crua ou mal passada. Além disso, doadores de sangue devem ser investigados previamente quanto à presença de marcadores da infecção.

Em 2012, a primeira vacina contra o vírus da hepatite E foi registrada na China para uso em indivíduos com mais de 16 anos (INNOVAX, 2012). Segundo o fabricante, é recomendada para pessoas com alto risco de infecção por HEV, incluindo aqueles que estão envolvidos na criação de animais, manipuladores de alimentos, estudantes, membros das forças armadas, mulheres em idade fértil, bem como os indivíduos que viajam para áreas endêmicas. Até o momento ainda não foi licenciada em outros países ou territórios (WHO, 2015).

\subsection{CONSIDERAÇÕES FINAIS}

A hepatite E é um problema de saúde pública mundial ainda não totalmente compreendido. Essa compreensão é essencial para o efetivo controle e prevenção da doença, tornando valiosos os estudos que vêm sendo conduzidos sobre o tema.

A epidemiologia da hepatite $\mathrm{E}$ é bastante complexa e requer ainda muitos estudos para sua elucidação, principalmente no Brasil, um país de dimensão continental, extremamente heterogêneo e detentor de enorme biodiversidade. 


\subsection{REFERÊNCIAS}

AGGARWAL, R.; KINI, D.; SOFAT, S.; NAIK, S.R.; KRAWCZYNSKI, K. Duration of viraemia and faecal viral excretion in acute hepatitis E. Lancet, vol.356, p.1081-1082, 2000.

AGGARWAL, R. \& NAIK, S. Epidemiology of hepatitis E: Current status. J Gastroenterol Hepatol, vol.24, p.1484-1493, 2009.

AGGARWAL, R. Clinical presentation of hepatitis E. Virus Res, vol.161, n.1, p.15-22, 2011.

AHMAD, I.; HOLLA, R.P.; JAMEEL, S. Molecular virology of hepatitis E virus. Virus Res, vol.161, p.47-58, 2011.

ALBINANA-GIMENEZ, N.; CLEMENTE-CASARES, P.; BOFILL-MAS, S.; HUNDESA, A.; RIBAS, F.; GIRONES, R. Distribution of human polyomaviruses, adenoviruses, and hepatitis E virus in the environment and in a drinking-water treatment plant. Environ Sci Technol, vol.40, n.23, p.7416-7422, 2006.

ALVARADO-ESQUIVEL, C.; SANCHEZ-ANGUIANO, L.F.; HERNANDEZ-TINOCO, J. Seroepidemiology of hepatitis $\mathrm{E}$ virus infection in general population in rural Durango, Mexico. Hepat Mon, vol.14, n.6, p.e16876, 2014.

ANIIŢĂ, A.; GORGAN, L.; ANIŢĂ, D.; OŞLOBANU, L.; PAVIO, N.; SAVUŢA, G. Evidence of hepatitis E infection in swine and humans in the East Region of Romania. Int J Infect Dis, vol.29, p.232-237, 2014.

ARANKALLE, V.A.; PARANJAPE, S.; EMERSON, S.U.; PURCELL, R.H.; WALIMBE, A.M. Phylogenetic analysis of hepatitis E virus isolates from India (1976-1993). J Gen Virol, vol.80, p.1691-1700, 1999.

ARANKALLE, V.A.; JOSHI, M.V.; KULKARNI, A.M.; GANDHE, S.S.; CHOBE, L.P.; RAUTMARE, S.S.; et al. Prevalence of anti-hepatitis E virus antibodies in different Indian animal species. J Viral Hepat, vol.8, n.3, p.223-7, 2001.

ARANKALLE, V.A.; CHOBE, L.P.; JOSHI, M.V.; CHADHA, M.S.; KUNDU, B.; WALIMBE, A.M. Human and swine hepatitis $\mathrm{E}$ viruses from Western India belong to different genotypes. J Hepatol, vol.36, n.3, p.417-425, 2002.

ASSIS, S.B.; SOUTO, F.J.D.; FONTES, C.J.F.; GASPAR, A.M.C. Prevalence of hepatitis A and $\mathrm{E}$ virus infection in school children of an Amazonian municipality in Mato Grosso State. Rev Soc Bras Med Trop, vol.35, p.155-158, 2002.

BALAYAN, M.S.; ANDJAPARIDZE, A.G.; SAVINSKAYA, S.S.; KETILADZE, E.S.; BRAGINSKY, D.M.; SAVINOV, A.P.; et al. Evidence for a virus in non-A, non-B hepatitis transmitted via the fecal-oral route. Intervirology, vol.20, p.23-31, 1983.

BALAYAN, M.S. Epidemiology of hepatitis E virus infection. J Viral Hep, vol.4, n.3, p.155166, 1997. 
BANKS, M.; BENDALL, R.; GRIERSON, S.; HEATH, G.; MITCHELL, J.; DALTON, H. Human and porcine hepatitis E virus strains, United Kingdom. Emerg Infect Dis, vol.5, p.953-955, 2004.

BARNAUD, E.; ROGÉE, S.; GARRY, P.; ROSE, N.; PAVIO, N. Thermal Inactivation of Infectious Hepatitis E virus in experimentally contaminated food. Appl Environ Microbiol, vol.78, n.15, p.5153-5159, 2012.

BAZERBACHI, F.; HAFFAR, S.; GARG, S.K.; LAKE, J.R. Extra-hepatic manifestations associated with hepatitis $\mathrm{E}$ virus infection: a comprehensive review of the literature. Gastroenterol Rep (Oxf), p.1-15, 2015.

BERTO, A.; GRIERSON, S.; HAKZE-VAN DER HONING, R.; MARTELLI, F.; JOHNE, R.; REETZ, J.; et al. Hepatitis E virus in pork liver sausage, France. Emerg Infect Dis, vol.19, n.2, 2013.

BORGEN, K.; HERREMANS, T.; DUIZER, E.; VENNEMA, H.; RUTJES, S.; BOSMAN, A.; et al. Non-travel related Hepatitis E virus genotype 3 infections in the Netherlands; a case series 2004 -2006. BMC Infect Dis, vol.8, p.61, 2008.

BORTOLIERO, A.L; BONAMETTI, A.M.; MORIMOTO, H.K.; MATSUO, T.; REICHE, E.M. Seroprevalence for hepatites E vírus (HEV) infection among volunteer blood donors of the regional blood bank of Londrina, state of Paraná, Brazil. Rev Inst Me. Trop Sao Paulo, vol.48, n.2, p.87-92, 2006.

BOSE, P.D.; DAS, B.C.; HAZAM, R.K.; KUMAR, A.; MEDHI, S.; KAR, P. Evidence of extrahepatic replication of hepatitis E virus in human placenta. J Gen Virol, vol.95, p.12661271, 2014.

BOUWKNEGT, M.; ENGEL, B.; HERREMANS, M.M.; WIDDOWSON, M.A.; WORM, H.C.; KOOPMANS, M.P.G.; et. al. Bayesian estimation of hepatitis E virus seroprevalence for populations with different exposure levels to swine in The Netherlands. Epidemiol Infect, v.136, p.567-576, 2008.

BOUWKNEGT, M.; RUTJES, S.A.; REUSKEN, C.B.; STOCKHOFE-ZURWIEDEN, N.; FRANKENA, K.; DE JONG, M.C.; et al. The course of hepatitis E virus infection in pigs after contact-infection and intravenous inoculation. BMC Vet Res, vol.5, p.7, 2009.

BOXALL, E.; HERBORN, A.; KOCHETHU, G.; PRATT, G.; ADAMS, D.; IJAZ, S.; et al. Transfusion-transmitted hepatitis E in a 'nonhyperendemic' country. Transfus Med, vol.16, n.2, p.79-83, 2006.

BRADLEY, D.W.; ANDJAPARIDZE, A.; COOK, E.H. JR.; MCCAUSTLAND, K.; BALAYAN, M.; STETLER, H.; et al. Aetiological agent of enterically transmitted non-A, non-B hepatitis. J Gen Virol, vol.69, p.731-738, 1988.

BRASIL, Ministério da Saúde, Secretaria de Vigilância em Saúde. Guia de vigilância epidemiológica. 6.ed. - Brasília: Ministério da Saúde, 2005. 
BRASIL, Ministério da Saúde, Secretaria de Vigilância em Saúde. Boletim Epidemiológico - Hepatites Virais. Ano III - nº 1. Brasília: Ministério da Saúde, 2012.

BRASIL, Ministério da Saúde, Secretaria de Vigilância em Saúde. Guia de Vigilância em Saúde. Vol. Único. Brasília: Ministério da Saúde, 2014.

BUISSON, Y.; GRANDADAM, M.; NICAND, E.; CHEVAL, P.; VAN CUYCK-GANDRE, H.; INNIS, B.; et al. Identification of a novel hepatitis E virus in Nigeria. J Gen Virol, vol.81, p.903-909, 2000.

CAO, D. \& MENG, X.J. Molecular biology and replication of hepatitis E virus. Emerg Microbes Infect, vol.1, n.8, p.e17, 2012.

CARDOSO, B.F.; OYAMADA, G.C.; SILVA, C.M. Produção, Tratamento e Uso dos Dejetos Suínos no Brasil. Desenvolvimento em Questão, Editora Unijuí, ano 13, n.32, p.127$145,2015$.

CASAS, M.; CORTES, R.; PINA, S.; PERALTA, B.; ALlEPUZ, A.; CORTEY, M.; et al. Longitudinal study of hepatitis E virus infection in Spanish farrow-to-finish swine herds. Vet Microbiol, vol.148, p.27-34, 2011.

CHANDRA, V.; TANEJA, S.; KALIA, M.; JAMEEL, S. Molecular biology and pathogenesis of hepatitis E virus. J Biosci, vol.33, p.451-464, 2008.

CHANDRA, N.S.; SHARMA, A.; MALHOTRA, B.; RAI, R.R. Dynamics of HEV viremia, fecal shedding and its relationship with transaminases and antibody response in patients with sporadic acute hepatitis E. Virol J, vol.7, p.213, 2010.

CHAUHAN, A.; JAMEEL, S.; DILAWARI, J.B.; CHAWLA, Y.K.; KAUR, U.; GANGULY, N.K. Hepatitis E virus transmission to a volunteer. Lancet, vol.341, p.149-150, 1993.

CHOI, C. \& CHAE, C. Localization of swine hepatitis E virus in liver and extrahepatic tissues from naturally infected pigs by in situ hybridization. J Hepatol, vol.38, n.6, p.827-832, 2003.

CHOI, I.S.; KWON, H.J.; SHIN, N.R.; YOO, H.S. Identification of swine hepatitis E virus (HEV) and prevalence of anti-HEV antibodies in swine and human populations in Korea. $\mathbf{J}$ Clin Microbiol, vol.41, n.8, p.3602-3608, 2003.

COLSON, P.; BORENTAIN, P.; QUEYRIAUX, B.; KABA, M.; MOAL, V.; GALLIAN, P.; et. al. Pig liver sausage as a source of hepatitis E virus transmission to humans. J Infect Dis, v.202, p.825- 834, 2010.

COOPER, K.; HUANG, F.F.; BATISTA, L.; RAYO, C.D.; BEZANILLA, J.C.; TOTH, T.E.; et al. Identification of genotype 3 hepatitis E virus (HEV) in serum and fecal samples from pigs in Thailand and Mexico, where genotype 1 and $2 \mathrm{HEV}$ strains are prevalent in the respective human populations. J Clin Microbiol, vol.43, n.4, p.1684-1688, 2005.

CROSSAN, C.; BAKER, P.J.; CRAFT, J.; TAKEUCHI, Y.; DALTON, H.R.; SCOBIE, L. Hepatitis E virus genotype 3 in shellfish, United Kingdom. Emerg Infect Dis, vol.18, n.12, p.2085-2087, 2012. 
DALTON, H.R.; BENDALL, R.; IJAZ, S.; BANKS, M. Hepatitis E: an emerging infection in developed countries. Lancet Infect Dis, vol.89, p.698-709, 2008.

DALTON, H.R.; BENDALL, R.P.; KEANE, F.E.; TEDDER, R.S.; IJAZ, S. Persistent carriage of hepatitis E virus in patients with HIV infection. N Engl J Med, vol.361, n.10, p.1025-1027, 2009.

DE CARVALHO, L.G.; MARCHEVSKY, R.S.; DOS SANTOS, D.R.; DE OLIVEIRA, J.M.; DE PAULA, V.S.; LOPES, L.M.; et al. Infection by Brazilian and Dutch swine hepatitis E virus strains induces haematological changes in Macaca fascicularis. BMC Infect Dis, vol.13, p.495, 2013.

DE DEUS, N.; SEMINATI, C.; PINA, S.; MATEU, E.; MARTÍN, M.; SEGALÉS, J. Detection of hepatitis $\mathrm{E}$ virus in liver, mesenteric lymph node, serum, bile and faeces of naturally infected pigs affected by different pathological conditions. Vet Microbiol, vol.19, p.105-114, 2007.

DE DEUS, N.; CASAS, M.; PERALTA, B.; NOFRARIAS, M.; PINA, S.; MARTÍN, M.; SEGALÉS, J. Hepatitis E virus infection dynamics and organic distribution in naturally infected pigs in a farrow-to-finish farm. Vet Microb, v.132, p.19-28, 2008.

DE PAULA, V.S.; WIELE, M.; MBUNKAH, A.H.; DANIEL, A.M.; KINGSLEY, M.T.; SCHMIDT-CHANASIT, J. Hepatitis E virus genotype 3 strains in domestic pigs, Cameroon. Emerg Infect Dis, vol.19, n.4, p.666-668, 2013.

DELl'AMICO, M.C.; CAVALlO, A.; GONZALES, J.L.; BONELLI, S.I.; VALDA, Y.; PIERI, A.; et al. Hepatitis E virus genotype 3 in humans and Swine, Bolivia. Emerg Infect Dis, vol.17, n.8, p.1488-1490, 2011.

DI BARTOLO, I.; PONTERIO, E.; CASTELLINI, L.; OSTANELLO, F.; RUGGERI, F.M. Viral and antibody HEV prevalence in swine at slaughterhouse in Italy. Vet Microbiol, vol.149, p.330-338, 2011.

DI BARTOLO, I.; ANGELONI, G.; PONTERIO, E.; OSTANELLO, F.; RUGGERI, F.M. Detection of hepatitis E virus in pork liver sausages. Int J Food Microbiol, vol.193, p.29-33, 2015.

DOS SANTOS, D.R.; VITRAL, C.L.; DE PAULA, V.S.; MARCHEVSKY, R.S.; LOPES, J.F.; GASPAR, A.M.; et al. Serological and molecular evidence of hepatitis E virus in swine in Brazil. Vet J, vol.182, p.474-480, 2009.

DOS SANTOS, D.R.; DE PAULA, V.S.; DE OLIVEIRA, J.M.; MARCHEVSKY, R.S.; PINTO, M.A. Hepatitis E virus in swine and effluent samples from slaughterhouses in Brazil. Vet Microbiol, v.149, p.236-241, 2011.

DROBENIUC, J.; FAVOROV, M.O.; SHAPIRO, C.N.; BELL, B.P.; MAST, E.E.; DADU, A.; et al. Hepatitis E virus antibody prevalence among persons who work with swine. J Infect Dis, vol.184, n.12, p.1594-1597, 2001. 
ECHEVARRÍA, J.M.; GONZÁLEZ, J.E.; LEWIS-XIMENEZ, L.L.; DOS SANTOS, D.R.; MUNNÉ, M.S.; PINTO, M.A.; et al. Hepatitis E virus infection in Latin America: a review. J Med Virol, vol.85, p.1037-1045, 2013.

EMERSON, S.U.; ANDERSON, D.; ARANKALlE, A.; MENG X.J.; PURDY, M.; SCHLAUDER, G.G.; et al. Virus taxonomy. VIIIth Report of International Committee on Taxonomy of Viruses. London: Elsevier/Academic Press, 2004. p.851-855.

EMERSON, S. U.; ARANKALLE, V. A.; PURCELL, R. H. Thermal stability of hepatitis E virus. J Infect Dis, v.192, p.930-933, 2005.

EMERSON, S.U.; NGUYEN, H.T.; TORIAN, U.; BURKE, D.; ENGLE, R.; PURCELL, R.H. Release of genotype 1 hepatitis E virus from cultured hepatoma and polarized intestinal cells depends on open reading frame 3 protein and requires an intact PXXP motif. J Virol, vol.84, p.9059-9069, 2010.

FARSHADPOUR, F.; TAHERKHANI, R.; MAKVANDI, M. Prevalence of hepatitis E virus among adults in South-West of Iran. Hepat Res Treat, vol.2015, p.759589, 2015.

FAVOROV, M.O.; FIELDS, H.A.; PURDY, M.A.; YASHINA, T.L.; ALEKSANDROV, A.G.; ALTER, M.J.; et al. Serologic identification of hepatitis E virus infections in epidemic and endemic settings. J Med Virol, vol.36, n.4, p.246-250, 1992.

FAVOROV, M.O.; KOSOY, M.Y.; TSAREV, S.A.; CHILDS, J.E.; MARGOLIS, H.S. Prevalence of antibody to hepatitis E virus among rodents in the United States. J Infect Dis, vol.181, n.2, p.449-455, 2000.

FEAGINS, A.R.; OPRIESSNIG, T.; GUENETTE, D.K.; HALBUR, P.G.; MENG, X.J. Detection and characterization of infectious Hepatitis E virus from commercial pig livers sold in local grocery stores in the USA. J Gen Virol, v.88, p.912-917, 2007.

FEAGINS, A.R.; OPRIESSNIG, T.; GUENETTE, D.K.; HALBUR, P.G.; MENG, X.J. Inactivation of infectious hepatitis $\mathrm{E}$ virus present in commercial pig livers sold in local grocery stores in the United States. Int J Food Microbiol, v.123, p.32-37, 2008.

FORGÁCH, P.; NOWOTNY, N.; ERDÉLYI, K.; BONCZ, A.; ZENTAI, J.; SZUCS, G.; REUTER, G.; BAKONYI, T. Detection of hepatitis E virus in samples of animal origin collected in Hungary. Vet Microbiol, vol.143, p.106-116, 2010.

GALIANA, C.; FERNÁNDEZ-BARREDO, S.; GARCÍA, A.; GÓMEZ, M.T.; PÉREZGRACIA, M.T. A short report: occupational exposure to hepatitis E virus (HEV) in swine workers. Am J Trop Med Hyg, vol.78, p.1012-1015, 2008.

GALIANA, C.; FERNÁNDEZ-BARREDO, S.; PÉREZ-GRACIA, M.T. Prevalencia del virus de la hepatitis E (VHE) y factores de riesgo en trabajadores de explotaciones porcinas y donantes voluntários. Enferm Infecc Microbiol Clin, vol.28, p.602-607, 2010.

GARBUGliA, A.R.; SCOGNAMIGLIO, P.; PETROSILlO, N.; MASTROIANNI, C.M.; SORDILLO, P.; GENTILE, D.; et al. Hepatitis E virus genotype 4 outbreak, Italy, 2011. Emerg Infect Dis, vol.19, n.1, p.110-114, 2013. 
GARCÍA, C.G.; SÁNCHEZ, D.; VILLALBA, M.C.; PUJOL, F.H.; LAY, L.L.R; PINTO, B.; et al. Molecular characterization of hepatitis $\mathrm{E}$ virus in patients with acute hepatitis in Venezuela. J Med Virol, vol.84, n.7, p.1025-1029, 2012.

GARDINALI, N.R.; BARRY, A.F.; OTONEL, R.A.; ALFIERI, A.F.; ALFIERI, A.A. Hepatitis $\mathrm{E}$ virus in liver and bile samples from slaughtered pigs of Brazil. Mem Inst Oswaldo Cruz, vol.107, n.7, p.935-939, 2012.

GARKAVENKO, O.; OBRIADINA, A.; MENG, J.; ANDERSON, D.A.; BENARD, H.J.; SCHROEDER, B.A.; et al. Detection and characterization of swine hepatitis E virus in New Zealand. J Med Virol, vol.65, n.3, p.525-529, 2001.

GENG, Y.; ZHAO, C.; SONG, A.; WANG, J.; ZHANG, X.; HARRISON, T.J.; et al. The serological prevalence and genetic diversity of hepatitis $\mathrm{E}$ virus in farmed rabbits in China. Infect Genet Evol, vol.11, n.2, p.476-482, 2011.

GENTRY-SHIELDS, J.; MYERS, K.; PISANIC, N.; HEANEY, C.; STEWART, J. Hepatitis $\mathrm{E}$ virus and coliphages in waters proximal to swine concentrated animal feeding operations. Sci Total Environ, vol.505, p.487-493, 2015.

GÉROLAMI, R.; MOAL, V.; COLSON, P. Chronic hepatitis E with cirrhosis in a kidney transplant recipient. N Engl J Med, vol.358, n.8, p.859-860, 2008.

GIRONES, R.; CARRATALÀ, A.; CALGUA, B.; CALVO, M.; RODRIGUEZ-MANZANO, J.; EMERSON, S. Chlorine inactivation of hepatitis $E$ virus and human adenovirus 2 in water. J Water Health, vol.12, n.3, p.436-442, 2014.

GONÇALES, N.S.; PINHO, J.R.; MOREIRA, R.C.; SARACENI, C.P.; SPINA, A.M.; STUCCHI, R.B.; et al. Hepatitis E virus immunoglobulin $G$ antibodies in different populations in Campinas, Brazil. Clin Diagn Lab Immunol, vol.7, n.5, p.813-816, 2000.

GRIERSON, S.; HEANEY, J.; CHENEY, T.; MORGAN, D.; WYLLIE, S.; POWELL, L.; et al. Prevalence of hepatitis E virus infection in pigs at the time of slaughter, United Kingdom, 2013. Emerg Infect Dis, vol.21, n.8, p.1396-1401, 2015.

GUIMARÃES, R.F.; SADDI, T.; PINTO, M.; VITRAL, C.L.; SOUTO, F.J. Hepatitis E virus antibodies in swine herds of Mato Grosso state, central Brazil. Braz J Microbiol, vol.36, p.223-226, 2005.

GUTIÉRREZ-VERGARA, C.; QUINTERO, J.; DUARTE, J.F.; SUESCÚN, J.P.; LÓPEZHERRERA, A. Detection of hepatitis E virus genome in pig livers in Antioquia, Colombia. Genet Mol Res, vol.14, n.1, p.2890-2899, 2015.

HAKZE-VAN DER HONING, R.W.; VAN COILLIE, E.; ANTONIS, A.F.; VAN DER POEL, W.H. First isolation of hepatitis E virus genotype 4 in Europe through swine surveillance in the Netherlands and Belgium. PLoS One, vol.6, n.8, p.e22673, 2011. 
HALBUR, P.G.; KASORNDORKBUA, C.; GILBERT, C.; GUENETTE, D.; POTTERS, M.B.; PURCELL, R.H.; et al. Comparative pathogenesis of infection of pigs with hepatitis $\mathrm{E}$ viruses recovered from a pig and a human. J Clin Microbiol, v.39, p.918-923, 2001.

HE, S.; MIAO, J.; ZHENG, Z., WU, T.; XIE, M.; TANG, M.; et al. Putative receptor-binding sites of hepatitis E virus. J Gen Virol, vol.89, p.245-249, 2008.

HELSEN, N.; DEBING, Y.; PAESHUYSE, J.; DALLMEIER, K.; BOON, R.; COLL, M.; et al. Stem cell-derived hepatocytes: A novel model for hepatitis E virus replication. J Hepatol, vol.64, n.3, p.565-573, 2016.

HOSMILLO, M.; JEONG, Y.J.; KIM, H.J.; PARK, J.G.; NAYAK, M.K.; ALFAJARO, M.M.; et al. Molecular detection of genotype 3 porcine hepatitis E virus in aborted fetuses and their sows. Arch Virol, vol.155, n.7, p.1157-1161, 2010.

HSIEH, S.; MENG, X.; WU, Y.; LIU, S.; TAM, A.; LIN, D.; et al. Identity of a novel swine hepatitis $\mathrm{E}$ virus in Taiwan forming a monophyletic group with Taiwan isolates of human hepatitis E virus. J Clin Microbiol, vol.37, p.3828-3834, 1999.

HUANG, C.C.;NGUYEN, D.; FERNANDEZ, J.; YUN, K.Y.; FRY, K.E.; BRADLEY, D.W.; et al. Molecular cloning and sequencing of the Mexico isolate of hepatitis $\mathrm{E}$ virus (HEV). Virology, vol.191, n.2, p.550-558, 1992.

INNOVAX. Recombinant Hepatitis E Vaccine. 2012. Disponível em: <http://www.innovax.cn/en/pro1.aspx?CateID=52\#103>. Acesso em: 04 out 2015.

IQBAL, T.; IDREES, M.; ALI, L.; HUSSAIN, A.; ALI, M.; BUTT, S.; et al. Isolation and characterization of two new hepatitis $E$ virus genotype 1 strains from two mini-outbreaks in Lahore, Pakistan. Virol J, vol.8, p.94, 2011.

ISHIDA, S.; YOSHIZUMI, S.; IKEDA, T.; MIYOSHI, M.; GOTO, A.; MATSUBAYASHI, $\mathrm{K}$; et al. Detection and molecular characterization of hepatitis $\mathrm{E}$ virus in clinical, environmental and putative animal sources. Arch Virol, vol.157, n.12, p.2363-2368, 2012.

IVANOVA, A.; TEFANOVA, V.; RESHETNJAK, I.; KUZNETSOVA, T.; GELLER, J.; LUNDKVIST, Å.; et al. Hepatitis E virus in domestic pigs, wild boars, pig farm workers, and hunters in Estonia. Food Environ Virol, vol.7, n.4, p.403-412, 2015.

KALIA, M.; CHANDRA, V.; RAHMAN, S.A.; SEHGAL, D.; JAMEEL, S. Heparan sulfate proteoglycans are required for cellular binding of the hepatitis E virus ORF2 capsid protein and for viral infection. J Virol, vol.83, p.12714-12724, 2009.

KAMAR, N.; SELVES, J.; MANSUY, J.M.; OUEZZANI, L.; PÉRON, J.M.; GUITARD, J.; et al. Hepatitis E virus and chronic hepatitis in organ-transplant recipients. N Engl J Med, vol.358, n.8, p.811-817, 2008.

KAMAR, N.; GARROUSTE, C.; HAAGSMA, E.B.; GARRIGUE, V.; PISCHKE, S.; CHAUVET, C.; et al. Factors associated with chronic hepatitis in patients with hepatitis E virus infection who have received solid organ transplants. Gastroenterology, vol.140, n.5, p.1481-1489, 2011. 
KAMAR, N.; DALTON, H.R.; ABRAVANEL, F.; IZOPET, J. Hepatitis E virus infection. Clin Microbiol Rev, vol.27, n.1, p.116-138, 2014.

KAMEL, A.H.; ALI, M.A.; EL-NADY, H.G.; DERAZ, A.; AHO, S.; POTHIER, P.; et al. Presence of enteric hepatitis viruses in the sewage and population of Greater Cairo. Clin Microbiol Infect, vol.17, n.8, p.1182-1185, 2011.

KASE, J.A.; CORREA, M.T.; LUNA, C.; SOBSEY, M.D. Isolation, detection and characterization of swine hepatitis E virus from herds in Costa Rica. Int J Environ Health Res, vol.18, n.3, p.165-176, 2008.

KASORNDORKBUA, C.; GUENETTE, D.K.; HUANG, F.F.; THOMAS, P.J.; MENG, X.J.; HALBUR, P.G. Routes of transmission of swine hepatitis E virus in pigs. J Clin Microbiol, vol.41, n.11, p.5047-5052, 2004.

KAWAI, H.F.; KOJI, T.; IIDA, F.; KANEKO, S.; KOBAYASHI, K.; NAKANE, P.K. Shift of hepatitis E virus RNA from hepatocytes to biliary epithelial cells during acute infection of rhesus monkey. J Viral Hepat, vol.6, n.4, p.287-297, 1999.

KHASKHELI, M.N.; BALOCH, S.; SHEEBA, A.; BALOCH, S. Hepatitis E - A preventable health issue - endangering pregnant women's life and foetal outcomes. J Pak Med Assoc, vol.65, n.6, p.655-659, 2015.

KHUDYAKOV, Y. \& KAMILI, S. Serological diagnostics of hepatitis E virus infection. Virus Res, vol.161, p.84-92, 2011.

KHUROO, M.S. Study of an epidemic of non-A, non-B hepatitis: possibility of another human hepatitis virus distinct from post-transfusion non-A, non-B type. Am J Med, vol.68, p.818-824, 1980.

KHUROO, M.S.; TELI, M.R.; SKIDMORE, S.; SOFI, M.A.; KHUROO, M.I. Incidence and severity of viral hepatitis in pregnancy. Am J Med, vol.70, n.2, p.252-255, 1981.

KHUROO, M.S.; KAMILI, S.; DAR, M.Y.; MOECKLII, R.; JAMEEL, S. Hepatitis E and long-term antibody status. Lancet, vol.341, p.1355, 1993.

KHUROO, M.S.; KAMILI, S.; JAMEEL, S. Vertical transmission of hepatitis E virus. Lancet, vol.345, p.1025-1026, 1995.

KHUROO, M.S., KAMILI, S., YATTOO, G.N. Hepatitis E virus infection may be transmitted through blood transfusions in an endemic area. J Gastroenterol Hepatol, vol.19, p.778-784, 2004.

KIM, J.H.; NELSON, K.E.; PANZNER, U.; KASTURE, Y.; LABRIQUE, A.B.; WIERZBA, T.F. A systematic review of the epidemiology of hepatitis E virus in Africa. BMC Infect Dis, vol.14, p.308, 2014.

KOONIN, E.V.; GORBALENYA, A.E.; PURDY, M.A.; ROZANOV, M.N.; REYES, G.R.; BRADLEY, D.W. Computer-assisted assignment of functional domains in the nonstructural 
polyprotein of hepatitis E virus: delineation of an additional group of positive-strand RNA plant and animal viruses. Proc Natl Acad Sci U.S.A, vol.89, p.8259-8263, 1992.

KRAWCZYNSKI, K.; MENG, X.J.; RYBCZYNSKA, J. Pathogenetic elements of hepatitis E and animal models of HEV infection. Virus Res, vol.161, p.78-83, 2011.

KRUMBHOLZ, A.; MOHN, U.; LANGE, J.; MOTZ, M.; WENZEL, J.J.; JILG, W.; et al. Prevalence of hepatitis E virus-specific antibodies in humans with occupational exposure to pigs. Med Microbiol Immunol, vol.201, n.2, p.239-244, 2012.

KUMAR, A.; BENIWAL, M.; KAR, P.; SHARMA, J.B.; MURTHY, N.S. Hepatitis E in pregnancy. Int J Gynaecol Obstet, vol.85, n.3, p.240-244, 2004.

KUMAR, A.S.; KUMAR, S.P.; SINGH, R.; KUMAR, M.S., MADAN, K.; KUMAR, J.J.; et al. Hepatitis E virus (HEV) infection in patients with cirrhosis is associated with rapid decompensation and death. J Hepatol, vol.46, p.387-394, 2007.

LA ROSA, G.; POURSHABAN, M.; IACONELLI, M.; VENNARUCCI, V.S.; MUSCILLO, M. Molecular detection of hepatitis E virus in sewage samples. Appl Environ Microbiol, vol.76, n.17, p.5870-5873, 2010.

LACK, J.B., VOLK, K.; VAN DEN BUSSCHE, R.A. Hepatitis E virus genotype 3 in wild rats, United States. Emerg Infect Dis, vol.18, p.1268-1273, 2012.

LAPA, D.; CAPOBIANCHI, M.R.; GARBUGLIA, A.R. Epidemiology of Hepatitis E Virus in European Countries. Int. J. Mol. Sci, vol.16, p.25711-25743, 2015.

LARSKA, M.; KRZYSIAK, M.K.; JABŁOŃSKI, A.; KĘSIK, J.; BEDNARSKI, M.; ROLA, J. Hepatitis E virus antibody prevalence in wildlife in Poland. Zoonoses Public Health, vol.62, n.2, p.105-110, 2015.

LAU, J.Y.; SALLIE, R.; FANG, J.W.; YARBOUGH, P.O.; REYES, G.R.; PORTMANN, B.C.; et al. Detection of hepatitis E virus genome and gene products in two patients with fulminant hepatitis E. J Hepatol, vol.22, n.6, p.605-610, 1995.

LEBLANC, D.; POITRAS, E.; GAGNÉ, M.J.; WARD, P.; HOUDE, A. Hepatitis E virus load in swine organs and tissues at slaughterhouse determined by real-time RT-PCR. Int J Food Microbiol, vol.139, n.3, p.206-209, 2010.

LEE, J.T.; SHAO, P.L.; CHANG, L.Y.; XIA, N.S.; CHEN, P.J.; LU, C.Y.; et al. Seroprevalence of hepatitis E virus infection among swine farmers and the general population in rural Taiwan. PLoS One, vol.8, n.6, pe67180, 2013.

LHOMME, S.; TOP, S.; BERTAGNOLI, S.; DUBOIS, M.; GUERIN, J.L.; IZOPET, J. Wildlife reservoir for hepatitis E virus, southwestern France. Emerg Infect Dis, vol.21, n.7, p.1224-1226, 2015.

LI, T.C.; YAMAKAWA, Y.; SUZUKI, K.; TATSUMI, M.; RAZAK, M.A.; UCHIDA, T.; et al. Expression and self-assembly of empty virus-like particles of hepatitis E virus. J Virol, vol.71, p.7207-7213, 1997. 
LI, T.C.; CHIJIWA, K.; SERA, N.; ISHIBASHI, T.; ETOH, Y.; SHINOHARA, Y.; et al. Hepatitis E virus transmission from wild boar meat. Emerg Infect Dis, vol.11, n.12, 2005.

LI, T.C.; YANG, T.; SHIOTA, T.; YOSHIZAKI, S.; YOSHIDA, H.; SAITO, M.; et al. Molecular detection of hepatitis E virus in rivers in the Philippines. Am J Trop Med Hyg, vol.90, n.4, p.764-766, 2014.

LI, T.C.; YONEMITSU, K.; TERADA, Y.; TAKEDA, N.; TAKAJI, W.; MAEDA, K. Ferret hepatitis E virus infection in Japan. Jpn J Infect Dis, vol.68, n.1, p.60-62, 2015.

LIANG, H.; SU, S.; DENG, S.; GU, H.; JI, F.; WANG, L.; et al. The prevalence of hepatitis E virus infections among swine, swine farmers and the general population in Guangdong Province, China. PLoS One, vol.9, n.2, p.e88106, 2014a.

LIANG, H.; CHEN, J.; XIE, J.; SUN, L.; JI, F.; HE, S.; et al. Hepatitis E virus serosurvey among pet $\operatorname{dog} s$ and cats in several developed cities in China. PLoS One, vol.9, n.6, p.e98068, 2014b.

LIN, J.; KARLSSON, M.; OLOFSON, A.S.; BELÁK, S.; MALMSTEN, J.; DALIN, A.M.; et al. High prevalence of hepatitis e virus in Swedish moose - a phylogenetic characterization and comparison of the virus from different regions. PLoS One, vol.10, n.4, p.e0122102, 2015.

LIU, P.; LI, L.; WANG, L.; BU, Q.; FU, H.; HAN, J.; et al. Phylogenetic analysis of 626 hepatitis E virus (HEV) isolates from humans and animals in China (1986-2011) showing genotype diversity and zoonotic transmission. Infect Genet Evol, vol.12, n.2, p.428-434, 2012.

LIU, X.; SAITO, M.; SAYAMA, Y.; SUZUKI, E.; MALBAS, F.F.JR; GALANG, H.O.; et al. Seroprevalence and molecular characteristics of hepatitis E virus in household-raised pig population in the Philippines. BMC Vet Res, vol.11, p.11, 2015.

LOPES DOS SANTOS, D.R.; LEWIS-XIMENEZ, L.L.; DA SILVA, M.F.; DE SOUSA, P.S.; GASPAR, A.M.; PINTO, M.A. First report of a human autochthonous hepatitis E virus infection in Brazil. J Clin Virol, vol.47, p.276-279, 2010.

LU, L.; LI, C.; HAGEDORN, C. H. Phylogenetic analysis of global hepatitis E virus sequences: genetic diversity, subtypes and zoonosis. Rev Med Virol, vol.16, p.35-36, 2006.

LYRA, A.C.; PINHO, J.R.; SILVA, L.K.; SOUSA, L.; SARACENI, C.P.; BRAGA, E.L.; et al. HEV, TTV and GBV-C/HGV markers in patients with acute viral hepatitis. Braz J Med Biol Res, vol.38, n.5, p.767-775, 2005.

MAILA, H.T.; BOWYER, S.M.; SWANEPOEL, R. Identification of a new strain of hepatitis E virus from an outbreak in Namibia in 1995. J Gen Virol, vol.85, p.89-95, 2004.

MALCOLM, P.; DALTON, H.; HUSSAINI, H.S.; MATHEW, J. The histology of acute autochthonous hepatitis E virus infection. Histopathology, vol.51, p.190-194, 2007. 
MANEERAT, Y.; CLAYSON, E.T.; MYINT, K.S.; YOUNG, G.D.; INNIS, B.L. Experimental infection of the laboratory rat with the hepatitis E virus. J Med Virol, vol.48, n.2, p.121-128, 1996.

MANSUY, J.M.; PERON, J.M.; ABRAVANEL, F.; POIRSON, H.; DUBOIS, M.; MIEDOUGE, M.; et al. Hepatitis $\mathrm{E}$ in the south west of France in individuals who have never visited an endemic area. J Med Virol, vol.74, n.3, p.419-424, 2004.

MARTINS, R.M.; FREITAS, N.R.; KOZLOWSKI, A.; REIS, N.R.; LOPES, C.L.; TELES, S.A.; GARDINALI, N.R.; PINTO, M.A. Seroprevalence of hepatitis E antibodies in a population of recyclable waste pickers in Brazil. J Clin Virol, vol.59, n.3, p.188-191, 2014.

MAST, E.E.; ALTER, M.J.; HOLLAND, P.V.; PURCELL, R.H. Evaluation of assays for antibody to hepatitis E virus by a serum panel. Hepatology, vol.27, n.3, p.857-861, 1998.

MATSUBAYASHI, K.; KANG, J.H.; SAKATA, H.; TAKAHASHI, K.; SHINDO, M.; KATO, M.; et al. A case of transfusion-transmitted hepatitis E caused by blood from a donor infected with hepatitis E virus via zoonotic food-borne route. Transfusion, vol.48, n.7, p.1368-1375, 2008.

MATSUDA, H.; OKADA, K.; TAKAHASHI, K.; MISHIRO, S. Severe hepatitis E virus infection after ingestion of uncooked liver from a wild boar. J Infect Dis, v.15, p.944, 2003.

MENG, X. J.; PURCELL, R. H.; HALBUR, P. G.; LEHMAN, J. R.; WEBB, D. M.; TSAREVA, T. S.; et. al. A novel virus in swine is closely related to the human hepatitis $\mathrm{E}$ virus. Proc Natl Acad Sci USA, vol. 94, p.9860-9865, 1997.

MENG, X.J.; HALBUR, P.G.; HAYNES, J.S.; TSAREVA, T.S.; BRUNA, J.D.; ROYER, R.L.; et al. Experimental infection of pigs with the newly identified swine hepatitis E virus (swine HEV), but not with human strains of HEV. Arch Virol, v.143, p.1405-1415, 1998.

MENG, X.J.; WISEMAN, B.; ELVINGER, F.; GUENETTE, D.K.; TOTH, T.E.; ENGLE, R.E.; et al. Prevalence of antibodies to hepatitis $E$ virus in veterinarians working with swine and in normal blood donors in the United States and other countries. J Clin Microbiol,.vol.40, p.117-122, 2002.

MENG, X.J. From barnyard to food table: The omnipresence of hepatitis E virus and risk for zoonotic infection and food safety. Virus Res, vol.161, p.23-30, 2011.

MIDGLEY, S.; VESTERGAARD, H.T.; DALGAARD, C.; ENGGAARD, L.; FISCHER, T.K. Hepatitis E virus genotype 4, Denmark, 2012. Emerg Infect Dis, vol.20, n.1, p.156-157, 2014.

MIRAZO, S.; RAMOS, N.; RUSSI, J.C.; ARBIZA, J. Genetic heterogeneity and subtyping of human Hepatitis E virus isolates from Uruguay. Virus Res, vol.173, n.2, p.364-370, 2013.

MIRAZO, S.; MAINARDI, V.; RAMOS, N.; GERONA, S.; ROCCA, A.; ARBIZA, J. Indigenous hepatitis E vírus genotype 1 infection, Uruguay. Emerg Infect Dis, vol.20, n.1, p.171-173, 2014. 
MIZUO, H.; SUZUKI, K.; TAKIKAWA, Y.; SUGAI, Y.; TOKITA, H.; AKAHANE, Y.; et al. Polyphyletic strains of hepatitis E virus are responsible for sporadic cases of acute hepatitis in Japan. J Clin Microbiol, vol.40, n.9, p.3209-3218, 2002.

MONNE, I.; CEGLIE, L.; DI MARTINO, G.; NATALE, A.; ZAMPROGNA, S.; MORREALE, A.; et al. Hepatitis E virus genotype 4 in a pig farm, Italy, 2013. Epidemiol Infect, vol.143, n.3, p.529-533, 2015.

MUNNÉ, M.S.; VLADIMIRSKY, S.; OTEGUI, L.; CASTRO, R.; BRAJTERMAN, L.; SOTO, S.; et al. Identification of the first strain of swine hepatitis E virus in South America and prevalence of anti-HEV antibodies in swine in Argentina. J Med Virol, vol.78, n.12, p.1579-1583, 2006.

MUNNÉ, M.S.; ALTABERT, N.R.; OTEGUI, M.L.O.; VLADIMIRSKY, S.N.; MOREIRO, R.; ESPUL, M.P.; et al. Updating the knowledge of hepatitis E: new variants and higher prevalence of anti-HEV in Argentina. Ann Hepatol, vol.13, n.5, p.496-502, 2014.

MURRAY, P. R.; ROSENTHAL, K. S.; PFALLER, M. A. Microbiologia Médica. 6 ed. Rio de Janeiro: Elsevier. 2009.

NAGASHIMA, S.; TAKAHASHI, M.; JIRINTAI; TANAKA, T.; YAMADA, K.; NISHIZAWA, T.; et al. A PSAP motif in the ORF3 protein of hepatitis E virus is necessary for virion release from infected cells. J Gen Virol, vol.92, p.269-278, 2011.

NAKAMURA, M.; TAKAHASHI, K.; TAIRA, K.; TAIRA, M.; OHNO, A.; SAKUGAWA, $\mathrm{H}$; , et al. Hepatitis E virus infection in wild mongooses of Okinawa, Japan: Demonstration of anti-HEV antibodies and a full-genome nucleotide sequence. Hepatol Res, vol.34, n.3, p.137$140,2006$.

NICAND, E.; ARMSTRONG, G.L.; ENOUF, V.; GUTHMANN, J.P.; GUERIN, J.P.; CARON, M.; et al. Genetic heterogeneity of hepatitis E virus in Darfur, Sudan, and neighboring Chad. J Med Virol, vol.77, n.4, p.519-521, 2005.

O'CONNOR, M.; ROCHE, S.J.; SAMMIN, D. Seroprevalence of hepatitis E virus infection in the Irish pig population. Ir Vet J, vol.68, p.8, 2015.

OHNISHI, S.; KANG, J.H.; MAEKUBO, H.; ARAKAWA, T.; KARINO, Y.; TOYOTA, J.; et al. Comparison of clinical features of acute hepatitis caused by hepatitis E virus (HEV) genotypes 3 and 4 in Sapporo, Japan. Hepatol Res, vol.36, p.301-307, 2006.

PAIVA, H.H.; TZANEVA, V.; HADDAD, R.; YOKOSAWA, J. Molecular characterization of swine hepatitis E virus from southeastern Brazil. Braz J Microbiol, vol.38, p.693-698, 2007.

PANDA, S.K. \& VARMA, S.P. Hepatitis e: molecular virology and pathogenesis. J Clin Exp Hepatol, vol.3, n.2, p.114-124, 2013.

PARANÁ, R.; COTRIM, H. P.; CORTEY-BOENNEC, M. L.; TREPO, C.; LYRA, L. Prevalence of hepatitis $\mathrm{E}$ virus $\mathrm{IgG}$ antibodies in patients from a referral unit of liver diseases in Salvador, Bahia, Brazil. Am J Trop Med Hyg, vol.57, n.1, p.60-61, 1997. 
PASSOS, A.M.; HERINGER, T.P.; MEDINA-PESTANA, J.O.; FERRAZ, M.L.; GRANATO, C.F. First report and molecular characterization of hepatitis E virus infection in renal transplant recipients in Brazil. J Med Virol, vol.85, n.4, p.615-619, 2013.

PASSOS-CASTILHO, A.M.; DE SENA, A.; REINALDO, M.R.; GRANATO, C.F. Hepatitis E virus infection in Brazil: results of laboratory-based surveillance from 1998 to 2013. Rev Soc Bras Med Trop, vol.48, n.4, p.468-470, 2015.

PATRA, S.; KUMAR, A.; TRIVEDI, S.S.; PURI, M.; SARIN, S.K. Maternal and fetal outcomes in pregnant women with acute hepatitis $\mathrm{E}$ virus infection. Ann Intern Med, vol.147, n.1, p.28-33, 2007.

PAVIO, N.; MERBAH, T.; THÉBAULT, A. Frequent Hepatitis E Virus Contamination in Food Containing Raw Pork Liver, France. Emerg Infect Dis, vol.20, n.11, 2014.

PERALTA, B.; CASAS, M.; DE DEUS, N.; MARTÍN, M.; ORTUÑO, A.; PÉREZMARTÍN, E.; et al. Anti-HEV antibodies in domestic animal species and rodents from Spain using a genotype 3-based ELISA. Vet Microbiol, vol.137, p.66-73, 2009.

PÉREZ-GRACIA, M.T.; GARCÍA, M.; SUAY, B.; MATEOS-LINDEMANN, M.L. Current Knowledge on Hepatitis E. J Clin Transl Hepatol, vol.3, n.2, p.117-126, 2015.

PINA, S.; BUTI, M.; COTRINA, M.; PIELLA, J.; GIRONES, R. HEV identified in serum from humans with acute hepatitis and in sewage of animal origin in Spain. J Hepatol, vol.33, p.826-833, 2000.

PSICHOGIOU, M.A.; TASSOPOULOS, N.C.; PAPATHEODORIDIS, G.Y.; TZALA, E.; KLARMANN, R.; WITTELER, H.; et al. Hepatitis E virus infection in a cohort of patients with acute non-A, non-B hepatitis. J Hepatol, vol.23, p.668-673, 1995.

RAMACHANDRAN, J.; EAPEN, C.E.; KANG, G.; ABRAHAM, P.; HUBERT, D.D.; KURIAN, G.; et al. Hepatitis E superinfection produces severe decompensation in patients with chronic liver disease. J Gastroenterol Hepatol, vol.19, n.2, p.134-138, 2004.

REIN, D.B.; STEVENS, G.A.; THEAKER, J.; WITTENBORN, J.S.; WIERSMA, S.T. The global burden of hepatitis E genotypes 1 and 2 in 2005. Hepatology, vol.55, n4, p.988-997, 2012.

RENOU, C.; ROQUE-AFONSO, A.M.; PAVIO, N. Foodborne transmission of hepatitis E virus from raw pork liver sausage, France. Emerg Infect Dis, vol.20, n.11, p.1945-1947, 2014.

REUTER, G.; FODOR, D.; FORGÁCH, P.; KÁTAI, A.; SZUCS, G. Characterization and zoonotic potential of endemic hepatitis $\mathrm{E}$ virus (HEV) strains in humans and animals in Hungary. J Clin Virol, vol.44, n.4, p.277-281, 2009.

REYES, G.R.; PURDY, M.A.; KIM, J.P.; LUK, K.C.; YOUNG, L.M.; FRY, K.E.; et al. Isolation of a cDNA from the virus responsible for enterically transmitted non-A, non-B hepatitis. Science, vol.247, p.1335-1339, 1990. 
ROLFE, K.J.; CURRAN, M.D.; MANGROLIA, N.; GELSON, W.; ALEXANDER, G.J.; L'ESTRANGE, M.; et al. First case of genotype 4 human hepatitis $E$ virus infection acquired in India. J Clin Virol, vol.48, n.1, p.58-61, 2010.

ROSE, N.; LUNAZZI, A.; DORENLOR, V.; MERBAH, T.; EONO, F.; ELOIT, M.; et al. High prevalence of Hepatitis $\mathrm{E}$ virus in French domestic pigs. Comp Immunol Microbiol Infect Dis, vol.34, n.5, p.419-427, 2011.

SAAD, M.D.; HUSSEIN, H.A.; BASHANDY, M.M.; KAMEL, H.H.; EARHART, K.C.; FRYAUFF, D.J.; et al. Hepatitis E virus infection in work horses in Egypt. Infect Genet Evol, vol.7, n.3, p.368-373, 2007.

SAID, B.; IJAZ, S.; KAFATOS, G.; BOOTH, L.; THOMAS, H.L.; WALSH, A.; et al. Hepatitis E outbreak on cruise ship. Emerg Infect Dis, vol.15, n.11, p.1738-1744, 2009.

SANTOS, D.C.; SOUTO, F.J.; SANTOS, D.R.; VITRAL, C.L.; GASPAR, A.M. Seroepidemiological markers of enterically transmitted viral hepatitis A and $\mathrm{E}$ in individuals living in a community located in the North Area of Rio de Janeiro, RJ, Brazil. Mem Inst Oswaldo Cruz, vol.97, n.5, p.637-640, 2002.

SANTOS, N. S. O.; ROMANOS, M. T. V.; WIGG, M. D. Introdução à virologia humana. 2 ed. Rio de Janeiro: Guanabara Koogan. 2013.

SCHLAUDER, G.G.; DESAI, S.M.; ZANETTI, A.R.; TASSOPOULOS, N.C.; MUSHAHWAR, I.K. Novel hepatitis E virus (HEV) isolates from Europe: evidence for

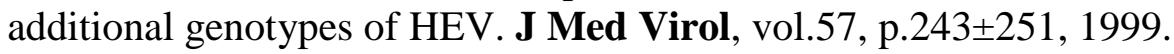

SCHLOSSER, J.; EIDEN, M.; VINA-RODRIGUEZ, A.; FAST, C.; DREMSEK, P.; LANGE, E.; et al. Natural and experimental hepatitis E virus genotype 3-infection in European wild boar is transmissible to domestic pigs. Vet Res, vol.45, p.121, 2014.

SHRESTHA, A.; LAMA, T.K.; KARKI, S.; SIGDEL, D.R.; RAI, U.; RAUNIYAR, S.K.; et al. Hepatitis E epidemic, Biratnagar, Nepal, 2014. Emerg Infect Dis, vol.21, n.4, p.711-713, 2015.

SHU, X.; DUAN, X.; SONG, C.; LI, J.; JIANG, L.; YIN, G.; et al. Genetic heterogeneity of swine hepatitis E virus isolates from Yunnan province, China in 2011-2012. Virol J, vol.11, p.162, 2014.

SILVA, S. M.; OLIVEIRA, J.M.; VITRAL, C.L.; VIEIRA, K.A.; PINTO, M.A.; SOUTO, F.J. Prevalence of hepatitis $\mathrm{E}$ virus antibodies in individuals exposed to swine in Mato Grosso, Brazil. Mem Inst Oswaldo Cruz, vol.107, n.3, p.338-341, 2012.

SMITH, D.B.; SIMMONDS, P.; JAMEEL, S.; EMERSON, S.U.; HARRISON, T.J.; MENG, X.J.; et al. Consensus proposals for classification of the family Hepeviridae. J Gen Virol, vol.95, p.2223-2232, 2014.

SONODA, H.; ABE, M.; SUGIMOTO, T.; SATO, Y.; BANDO, M.; FUKUI, E.; et al. Prevalence of hepatitis E virus (HEV) Infection in wild boars and deer and genetic 
identification of a genotype $3 \mathrm{HEV}$ from a boar in Japan. J Clin Microbiol, vol.42, n.11, p.5371-5374, 2004.

SOUZA, A.J.S.; GOMES-GOUVÊA, M.S.; SOARES, M.C.P.; PINHO, J.R.R.; MALHEIROS, A.P.; CARNEIRO, L.A.; et al. HEV infection in swine from Eastern Brazilian Amazon: Evidence of co-infection by different subtypes. Comp Immunol Microbiol Infect Dis, vol.35, p.477-485, 2012.

STEYER, A.; NAGLIČ, T.; MOČILNIK, T.; POLJŠAK-PRIJATELJ, M.; POLJAK, M. Hepatitis E virus in domestic pigs and surface waters in Slovenia: prevalence and molecular characterization of a novel genotype 3 lineage. Infect Genet Evol, vol.11, n.7, p.1732-1737, 2011.

SUN, Z.F.; LARSEN, C.T.; HUANG, F.F.; BILLAM, P.; PIERSON, F.W.; TOTH, T.E.; et al. Generation and infectivity titration of an infectious stock of avian hepatitis E virus (HEV) in chickens and cross-species infection of turkeys with avian HEV. J Clin Microbiol, vol.42, n.6, p.2658-2662, 2004.

SURJIT, M.; JAMEEL, S.; LAL, S.K. The ORF2 protein of hepatitis E virus binds the 59 region of viral RNA. J Virol, vol.78, p.320-328, 2004.

SUWANNAKARN, K.; TONGMEE, C.; THEAMBOONLERS, A.; KOMOLMIT, P.; POOVORAWAN, Y. Swine as the possible source of hepatitis E virus transmission to humans in Thailand. Arch Virol, vol.155, n.10, p.1697-1699, 2010.

TAKAHASHI, M.; TANAKA, T.; AZUMA, M.; KUSANO, E.; AIKAWA, T.; SHIBAYAMA, T.; et al. Prolonged Fecal Shedding of Hepatitis E Virus (HEV) during Sporadic Acute Hepatitis E: Evaluation of Infectivity of HEV in Fecal Specimens in a Cell Culture System. J Clin Microbiol, vol.45, n.11, p.3671, 2007.

TAM, A.W.; SMITH, M.M.; GUERRA, M.E.; HUANG, C.C.; BRADLEY, D.W.; FRY, K.E.; et al. Hepatitis E virus (HEV): Molecular cloning and sequencing of the full-length viral genome. Virology, vol.185, p.120-131, 1991.

TEI, S., KITAJIMA, N., TAKAJASHI, K., MISHIRO, S. Zoonotic transmission of hepatitis E virus from deer to humans beings. Lancet, vol.362, p.371-373, 2003.

TEI, S.; KITAJIMA, N.; OHARA, S.; INOUE, Y.; MIKI, M.; YAMATANI, T.; et al. Consumption of uncooked deer meat as a risk factor for Hepatitis E Virus infection: an ageand sex-matched case-control study. J Med Virol, v.74, p.67-70, 2004.

TEO, C.G. Fatal outbreaks of jaundice in pregnancy and the epidemic history of hepatitis E. Epidemiol Infect, vol.140, n.5, p.767-787, 2012.

TESHALE, E.H.; HOWARD, C.M.; GRYTDAL, S.P.; HANDZEL, T.R.; BARRY, V.; KAMILI, S.; et al. Hepatitis E Epidemic, Uganda. Emerg Infect Dis, vol.16, n.1, 2010a.

TESHALE, E.H.; GRYTDAL, S.P.; HOWARD, C.; BARRY, V.; KAMILI, S.; DROBENIUC J.; et al. Evidence of person-to-person transmission of hepatitis E virus during a large outbreak in Northern Uganda. Clin Infect Dis, vol.50, n.7, p.1006-1010, 2010 b. 
TESHALE, E.H.; HU, D.J.; HOLMBERG, S.D. The two faces of hepatitis E virus. Clin Infect Dis, vol.51, p.328-334, 2010c.

TESSÉ, S.; LIOURE, B.; FORNECKER, L.; WENDLING, M.J.; STOLL-KELLER, F.; BIGAILLON, C.; et al. Circulation of genotype 4 hepatitis $\mathrm{E}$ virus in Europe: first autochthonous hepatitis E infection in France. J Clin Virol, vol.54, n.2, p.197-200, 2012.

TOHME, R.A.; DROBENIUC, J.; SANCHEZ, R.; HESELTINE, G.; ALSIP, B.; KAMILI, S.; et al. Acute hepatitis associated with autochthonous hepatitis E virus infection - San Antonio, Texas, 2009. Clin Infect Dis, vol.53, n.8, p.793-796, 2011.

TRINTA, K.S.; LIBERTO, M.I.; DE PAULA, V.S.; YOSHIDA, C.F.; GASPAR, A.M. Hepatitis E virus infection in selected Brazilian populations. Mem Inst Oswaldo Cruz, vol.96, n.1, p.25-29, 2001.

USMANOV, R.K.; BALAIAN, M.S.; DVOINIKOVA, O.V.; ALYMBAEVA, D.B.; ZAMIATINA, N.A.; KAZACHKOV, IU.A.; et al. An experimental infection in lambs by the hepatitis E virus. Vopr Virusol, vol.4, p.165-168, 1994.

VASCONCELOS, J.; SOLIMAN, M.C.; STAGGEMEIER, R.; HEINZELMANN, L.; WEIDLICH, L.; CIMIRRO, R.; et al. Molecular detection of hepatitis E virus in feces and slurry from swine farms, Rio Grande do Sul, Southern Brazil. Arq Bras Med Vet Zootec, vol.67, n.3, p.777-782, 2015.

VILLALBA, M.C.M.; LAY, L.L.; CHANDRA, V.; CORREDOR, M.B.; FROMETA, S.S.; MORENO, A.G.; et al. Hepatitis E virus genotype 1, Cuba. Emerg Infect Dis, vol.14, n.8, p.1320-1322, 2008.

VILLALBA, M.C.M.; OWOT, J.C.; BENEDITO, E.C.; CORREDOR, M.B.; FLAQUET, P.P.; FROMETA, S.S.; et al. Hepatitis E virus genotype 3 in humans and swine, Cuba. Infect Genet Evol, vol.14, p.335-339, 2013.

VITRAL, C.L.; PINTO, M.A.; LEWIS-XIMENEZ, L.L.; KHUDYAKOV, Y.E.; SANTOS, D.R.; GASPAR, A.M. Serological evidence of hepatitis E virus infection in different animal species from the Southeast of Brazil. Mem Inst Oswaldo Cruz, vol.100, p.2117-2217, 2005.

VITRAL, C.L.; DA SILVA-NUNES, M.; PINTO, M.A.; DE OLIVEIRA, J.M.; GASPAR, A.M; PEREIRA. R.C.; et al. Hepatitis A and E seroprevalence and associated risk factors: a community-based cross-sectional survey in rural Amazonia. BMC Infect Dis, vol.14, p.458, 2014.

WALACHOWSKI, S.; DORENLOR, V.; LEFEVRE, J.; LUNAZZI, A.; EONO, F.; MERBAH, T.; et al. Risk factors associated with the presence of hepatitis E virus in livers and seroprevalence in slaughter-age pigs: a retrospective study of 90 swine farms in France. Epidemiol Infect, vol.142, n.9, p.1934-1944, 2014.

WENZEL, J.J.; PREISS, J.; SCHEMMERER, M.; HUBER, B.; PLENTZ, A.; JILG, W. Detection of hepatitis E virus (HEV) from porcine livers in Southeastern Germany and high sequence homology to human HEV isolates. J Clin Virol, vol.52, n.1, p.50-54, 2011. 
WHO, World Health Organization. Hepatitis E vaccine: WHO position paper, May 2015. Wkly Epidemiol Rec, vol. 90, n.18, p.185-200, 2015.

WILLIAMS, T.P.; KASORNDORKBUA, C.; HALBUR, P.G.; HAQSHENAS, G.; GUENETTE, D.K.; TOTH, T.E.; et al. Evidence of extrahepatic sites of replication of the hepatitis E virus in a swine model. J Clin Microbiol, vol.39, p.3040-3046, 2001.

WOO, P.C.; LAU, S.K.; TENG, J.L.; TSANG, A.K.; JOSEPH, M.; WONG, E.Y.; et al. New hepatitis E virus genotype in camels, the Middle East. Emerg Infect Dis, vol.20, n.6, p.10441048, 2014.

WU, J.C.; CHEN, C.M.; CHIANG, T.Y.; SHEEN, I.J.; CHEN, J.Y.; TSAI, W.H.; et al. Clinical and epidemiological implications of swine hepatitis E virus infection. J Med Virol, vol.60, p.166-171, 2000.

WU, J.; SI, F.; JIANG, C.; LI, T.; JIN, M. Molecular detection of hepatitis E virus in sheep from southern Xinjiang, China. Virus Genes, vol.50, n.3, p.410-417, 2015.

XING, L.; WANG, J.C.; LI, T.C.; YASUTOMI, Y.; LARA, J.; KHUDYAKOV, Y.; et al. Spatial configuration of hepatitis E virus antigenic domain. J Virol, vol.85, p.1117-1124, 2011.

YAMADA, K.; TAKAHASHI, M.; HOSHINO, Y.; TAKAHASHI, H.; ICHIYAMA, K.; NAGASHIMA, S.; et al. ORF3 protein of hepatitis E virus is essential for virion release from infected cells. J Gen Virol, vol.90, p.1880-1891, 2009.

YAMADA, H.; TAKAHASHI, K.; LIM, O.; SVAY, S.; CHUON, C.; HOK, S.; et al. Hepatitis E virus in Cambodia: Prevalence among the general population and complete genome sequence of genotype 4. PLoS One, vol.10, n.8, p.e0136903, 2015.

YARBOUGH, P.; TAM, A.W.; FRY, K.E.; KRAWCZYNSKI, K.; MCCAUSTLAND, K.A.; BRADLEY, D.W.; et al. Hepatitis E virus: identification of type-common epitopes. J Virol, vol.65, n.11, p.5790-5797, 1991.

YAZAKI, Y.; MIZUO, H.; TAKAHASHI, M.; NISHIZAWA, T.; SASAKI, N.; GOTANDA, Y.; et al. Sporadic acute or fulminant hepatitis E in Hokkaido, Japan, may be foodborne, as suggested by the presence of hepatitis E virus in pig liver as food. J Gen Virol, v.84, p.23512357, 2003.

YOON, Y.; JEONG, H.S.; YUN, H.; LEE, H.; HWANG, Y.S.; PARK, B.; et al. Hepatitis E Virus (HEV) seroprevalence in the general population of the Republic of Korea in 2007-2009: a nationwide cross-sectional study. BMC Infect Dis, vol.14, p.517, 2014.

YU, H.; LI, S.; YANG, C.; WEI, M.; SONG, C.; ZHENG, Z.; et al. Homology model and potential virus-capsid binding site of a putative HEV receptor Grp78. J Mol Model, vol.17, p.987-995, 2011.

ZAAIJER, H.L.; KOK, M.; LELIE, P.N.; TIMMERMAN, R.J.; CHAU, K.; VANDERPAL, H.J. Hepatitis E in the Netherlands. Imported and endemic. Lancet, vol.341, p.286, 1993. 
ZAFRULLAH, M.; OZDENER, M.H.; PANDA, S.K.; JAMEEL, S. The ORF3 protein of hepatitis $\mathrm{E}$ virus is a phosphoprotein that associates with the cytoskeleton. J Virol, vol.71, n.12, p. 9045-9053, 1997.

ZANETTI, A.R. \& DAWSON, G.J. Hepatitis Type E in Italy: a seroepidemiological survey. J Med Virol, vol.42, p.318-320, 1994.

ZHENG, Z.Z.; MIAO, J.; ZHAO, M.; TANG, M.; YEO, A.E.; YU, H.; et al. Role of heatshock protein 90 in hepatitis E virus capsid trafficking. J Gen Virol; vol.91, p.1728-1736, 2010 .

ZHOU, Y. \& EMERSON, S.U. P.302 Heat shock cognate protein 70 may mediate the entry of hepatitis E virus into host cells. J Clin Virol, vol.36, p.S155, 2006. 


\section{INFORMAÇÕES ADICIONAIS}

O capítulo seguinte encontra-se formatado segundo as normas do sistema de submissão de artigos para publicação no periódico Pesquisa Veterinária Brasileira. 


\title{
CAPÍTULO II
}

\section{Seroprevalence of hepatitis $\mathbf{E}$ virus infection in domestic pigs in the Federal District, Brazil}

\author{
Luciana F.L.S. Vilanova ${ }^{1 *}$, Luciana L. Rigueira ${ }^{1}$, Simone Perecmanis ${ }^{1}$
}

\begin{abstract}
.-
Hepatitis E is caused by hepatitis E virus (HEV) which is currently known to be a zoonotic pathogen and it has pigs as reservoirs. In Brazil, there is no information about the circulation of HEV in swine flocks of the Federal District. Therefore, a cross-sectional study was performed with sera from 449 domestic pigs, provided by the Secretary of Agriculture of the Federal District. Blood samples were collected between June and September 2014. An ELISA kit commercially available was used for the detection of IgG antibodies. It was found a high seroprevalence of antibodies to HEV, since 304 animals showed anti-HEV positive reactions $(67.7 \% ; 95 \% \mathrm{CI}=63.2 \%, 71.9 \%)$. The seropositivity presented no difference by gender or age. The results suggest that HEV circulates among domestic pigs in the Federal District, and it can serve as a warning to the local public health system about their possible involvement in human infections.
\end{abstract}

INDEX TERMS: Hepatitis E, swine, Federal District, Brazil.

RESUMO.- [Soroprevalência da infecção pelo vírus da hepatite $\mathbf{E}$ em suínos domésticos no Distrito Federal, Brasil] A hepatite E é causada pelo vírus da hepatite E (HEV), considerado um patógeno de transmissão zoonótica e que possui suínos como reservatórios. No Brasil, não há informações a respeito da circulação do HEV no rebanho suíno do Distrito Federal. Por isso, foi conduzido um estudo transversal com amostras de soro de 449 suínos domésticos provenientes de 234 propriedades, cedidas pela Secretaria de Agricultura do Distrito Federal. As amostras sanguíneas foram coletadas entre junho e setembro de 2014. Um kit de ELISA comercialmente disponível foi utilizado para a detecção sorológica de anticorpos IgG contra o HEV. Foi encontrada uma alta soroprevalência de anticorpos contra o HEV, uma vez que 304 animais apresentaram amostras reagentes $(67,7 \%$, IC 95\% $=63,2 \%$, $71,9 \%$ ). A soropositividade não variou com relação ao gênero ou à idade. Os resultados sugerem que o HEV circula entre os suínos domésticos no Distrito Federal, e isso pode servir como um alerta para o sistema de saúde pública da região devido ao possível envolvimento desses animais em infecções humanas.

TERMOS DE INDEXAÇÃO: Hepatite E, suínos, Distrito Federal, Brasil.

${ }^{1}$ Faculdade de Agronomia e Medicina Veterinária, Universidade de Brasília. Instituto Central de Ciências, Campus Universitário Darcy Ribeiro, Asa Norte. Brasília - DF, Brazil. CEP: 70910-970 Tel.: 5561 3107-7122 Fax: 5561 3107-7118. *Corresponding author: lu.flsouza@ gmail.com 


\section{INTRODUCTION}

Hepatitis E is an important public-health concern and is a major cause of enterically transmitted hepatitis worldwide. The disease is caused by the hepatitis E virus (HEV) (Tam et al. 1991) which is currently known to be a zoonotic pathogen with pigs as reservoirs (Meng 2006). Humans and pigs share the HEV genotypes 3 and 4 (HEV-3 and HEV-4) (Smith et al., 2014) that seem to circulate in many countries such as Brazil (Paiva et al. 2007, Lopes dos Santos et al. 2010).

Swine transmit the disease to humans through the consumption of raw or undercooked meat, the directly exposure to the animals or their feces and the environmental contamination of water sources (Yugo \& Meng 2013). The infection in pigs is asymptomatic and mostly occurs at the age of 2-4 months (Meng et al. 1997).

In Brazil, human hepatitis $E$ is a notifiable disease (Brasil 2005). Outbreaks of the disease have never been reported despite the fact that the environmental conditions and sanitation in some regions favor the transmission (Brasil 2014). However, autochthonous cases have already been reported (Lopes dos Santos et al. 2010, Brasil 2012).

According to data from Brazilian Ministry of Health, from 1999 to 2011 there were 967 confirmed cases and 86 deaths reported by hepatitis E in the country (Brasil 2012). No latest official data is published about the disease. The Ministry of Health recognizes that many cases may not have been registered leading to high underreporting. This could be happening due to the broad spectrum of this disease and the considerable proportion of asymptomatic cases that remain unknown to the surveillance system (Brasil 2012). Therefore, the lack of a national epidemiological study about the disease hinders the knowledge of its real situation in the country.

The swine production has an important role in Brazilian livestock economy. The country is today the fourth largest producer and exporter of pork (USDA 2015). However, there are few studies about the prevalence of HEV in domestic swine herd. Moreover, in two of these studies conducted in the states of Mato Grosso and Rio de Janeiro, a high seroprevalence of HEV was found in pigs (Guimarães et al. 2005, Vitral et al. 2005).

Thus, a cross-sectional study was performed in order to estimate the seroprevalence of hepatitis $\mathrm{E}$ virus infection among domestic pigs from different localities in the Federal District, Brazil.

\section{MATERIALS AND METHODS}

The sample size calculation to estimate the true prevalence considered a assumed prevalence of 0.75 (based on the results of similar studies conducted in other states of the country), a population size of 163,985 (provided by the Secretary of Agriculture of Federal District and related to the year of 2014), an assumed sensitivity of 0.9096 and an assumed specificity of 0.9404 (ThermoFisher Scientific 2015), a confidence level of 0.95 and a desired precision of 0.5 .

This way, 449 serum samples were randomly selected. They were provided by the Secretary of Agriculture of Federal District and they belonged to 234 farms situated in 12 localities (Brazlândia, Ceilândia, Gama, Paranoá, Planaltina, Recanto das Emas, Riacho Fundo, Samambaia, Santa Maria, São Sebastião, Sobradinho and Taguatinga) (Fig. 1).

The samples were collected from June to September 2014 and they were stored in microtubes at $-18^{\circ} \mathrm{C}$ until the time of analysis. Each sample was collected from the jugular vein of male and female domestic pigs that were born at their respective farms. These animals were between 6 and 48 months of age and there was no information about their breed. In order to compare the ages, pigs were subdivided in two categories: young animals (6-10 months) and adult animals (11-48 months). 
The standard gathering data consisted in a questionnaire applied, which included information such as contact with wild swine, contact with pigs from other establishments, if there was the arrival of new animals, if the owner had other farms in other countries, the supply of food waste and the proximity to nature reserves, protected areas or national parks with wild swine. This information was used to evaluate possible risk factors.

Swine IgG antibodies against HEV were detected in sera samples by the commercial enzyme-linked immunosorbent assay PrioCHECK ${ }^{\circledR} \mathrm{HEV}$ Ab porcine in accordance with the manufacturer's instructions. This kit is the only commercially available ELISA based on recombinant ORF2- and 3-derived antigens of HEV genotypes 1 and 3, which significantly improves the specificity and sensitivity of the test (ThermoFisher Scientific 2015).

EpiTools ${ }^{\circledR}$ program (Sergeant 2015) was used to calculate the sample size and to estimate true prevalence, whereas the chi-square test $\left(\mathrm{x}^{2}\right)$ was used to compare the seroprevalence between genders and ages. A p value $<0.05$ was considered statistically significant. Odds ratio with a $95 \%$ confidence interval was used to evaluate possible risk factors.

All procedures of this work were approved by the University of Brasilia Ethics Committee on Animal Use (CEUA-UnB) (UnBDoC n ${ }^{\circ}$ 43447/2014).

\section{RESULTS}

Of the 449 animals tested, 304 showed anti-HEV positive reactions $(67.7 \%, 95 \% \mathrm{CI}=$ $63.2 \%, 71.9 \%)$. There was no difference of seroprevalence by gender $(\mathrm{p}=0.1)$ or age $(\mathrm{p}=0.58)$ (Tab. 1 and 2). The seroprevalence among farms ranged from $0.0 \%$ to $85.7 \%$ (Tab. 3 ).

\section{DISCUSSION}

A high prevalence of anti-HEV IgG was detected in domestic pigs in the Federal District, such as Guimarães et al. (2005) in Mato Grosso state and Vitral et al. (2005) in Rio de Janeiro state. Guimarães et al. (2005) tested 260 animals from 13 different counties and found a prevalence of anti-HEV IgG of $81.2 \%$. Vitral et al. (2005) also detected a high prevalence of anti-HEV antibodies by analyzing 357 swine sera $(63.6 \%)$. On the other hand, in Pará state, only 13 of 151 samples of swine sera (8.6\%) were positive for anti-HEV IgG (de Souza et al. 2012).

The anti-HEV prevalence ranged widely among the farms but this could be due to small samples collected in some regions.

Throughout the world there are a number of studies that have reported the detection of anti-HEV IgG antibodies in pigs. The seroprevalence of anti-HEV antibodies in swine in European countries varies from $27 \%$ to $92.8 \%$ (Grierson et al. 2015, O'Connor et al. 2015). In Asia the prevalence is still significant and varies from $14.8 \%$ to $64.7 \%$ (Choi et al. 2003, Liang et al. 2014). In the Americas, the seroprevalence of swine anti-HEV antibodies also ranges widely from $22.7 \%$ to $80 \%$ (Cooper et al. 2005, Munné et al. 2006). However, in Brazil, these serologic studies are still scarce once they appear to be until now limited to only 4 of the 27 states.

This wide variability on swine HEV seroprevalence results can be due to different specificity and sensibility of the serological assays used (Khudyakov \& Kamili 2011). Besides, some studies have shown that HEV prevalence is straightly associated with differences in the hygiene and sanitary management of the rearing facilities (Casas et al. 2011, Walachowski et al. 2014).

There was no difference in prevalence between genders $(\mathrm{p}=0.1)$ and age classes ( $\mathrm{p}=0.58$ ), once again according to Guimarães et al. (2005) findings. This can be explained because both studies analyzed only young and adult samples and the disease appears to have 
no preference among genders. The exclusion of younger pigs was due to the presence of maternal antibodies (dos Santos et al. 2009).

The most common way of HEV transmission among pigs is fecal-oral, such as with humans. Pigs become infected when the contact with other infected pig occurs randomly or through the ingestion of water or food contaminated with feces (Kasorndorkbua et al. 2004).

Unfortunately, it was not possible to establish risk factors because of the small number of animals exposed to the majority of investigated conditions, although it is known that the introduction of new animals in the herd could facilitate the transmission of several diseases and the contact with wild boars was shown to be another source of transmission to pigs (Schlosser et al. 2014). Besides that, most of the pigs received food waste, but the proportion of positive animals was very similar in both exposed and non-exposed groups. Therefore, any association between the consumption of food waste and the presence of antibodies to the disease was not found, although it is known that the supply of food waste could be a risk factor due to its easy contamination with animal feces.

\section{CONCLUSIONS}

Hepatitis E virus circulates among domestic pigs in the Federal District of Brazil, and it serves as a warning to the local public health system due to a possible involvement of this animal in human infections. Moreover, the high seroprevalence found in the region helps to better understand the epidemiology of this disease. It is also important to obtain more information to program control strategies in order to prevent zoonotic transmission still at an early stage. Although most infections in pigs are subclinical and the economic impact for farmers is low, swine HEV infection poses a serious public health problem once it is still poorly explored in Brazil.

Acknowledgements.- The authors would like to thank the veterinarians from the Secretary of Agriculture of the Federal District for their support and assistance and CAPES for the financial support.

\section{REFERENCES}

Brasil, Ministério da Saúde. 2005. Secretaria de Vigilância em Saúde. Guia de vigilância epidemiológica. 6 ed. Brasília: Ministério da Saúde.

Brasil, Ministério da Saúde. 2012. Secretaria de Vigilância em Saúde. Boletim Epidemiológico - Hepatites Virais. Ano III - no 1. Brasília: Ministério da Saúde.

Brasil, Ministério da Saúde. 2014. Secretaria de Vigilância em Saúde. Guia de Vigilância em Saúde. Brasília: Ministério da Saúde.

Casas M., Cortes R., Pina S., Peralta B., Allepuz A., Cortey M., Casal J. \& Martín M. 2011. Longitudinal study of hepatitis $\mathrm{E}$ virus infection in Spanish farrow-to-finish swine herds. Vet. Microbiol. 148:27-34.

Choi I.S., Kwon H.J., Shin N.R. \& Yoo H.S. 2003. Identification of Swine Hepatitis E Virus (HEV) and Prevalence of Anti-HEV Antibodies in Swine and Human Populations in Korea. J. Clin. Microbiol. 41(8):3602-3608.

Cooper K., Huang F.F., Batista L., Rayo C.D., Bezanilla J.C., Toth T.E. \& Meng X.J. 2005. Identification of Genotype 3 Hepatitis E Virus (HEV) in Serum and Fecal Samples from 
Pigs in Thailand and Mexico, Where Genotype 1 and 2 HEV Strains Are Prevalent in the Respective Human Populations. J. Clin. Microbiol. 43(4):1684-1688.

de Souza A.J., Gomes-Gouvêa M.S., Soares M.C., Pinho J.R., Malheiros A.P., Carneiro L.A., dos Santos D.R. \& Pereira W.L. 2012. HEV infection in swine from Eastern Brazilian Amazon: Evidence of co-infection by different subtypes. Comp. Immunol. Microbiol. Infect. Dis. 35:477-485.

dos Santos D.R., Vitral C.L., de Paula V.S., Marchevsky R.S., Lopes J.F., Gaspar A.M., Saddi T.M., Júnior M.C., Guimarães F.R., Júnior J.D., Ximenes L.L., Souto F.J. \& Pinto M.A. 2009. Serological and molecular evidence of hepatitis E virus in swine in Brazil. Vet. J. 182:474-480.

Grierson S., Heaney J., Cheney T., Morgan D., Wyllie S., Powell L., Smith D., Ijaz S., Steinbach F., Choudhury B. \& Tedder R.S. 2015. Prevalence of Hepatitis E Virus Infection in Pigs at the Time of Slaughter, United Kingdom, 2013. Emerg. Infect. Dis. 21(8):13961401.

Guimarães F.R., Saddi T.M., Vitral C.L., Pinto M.A., Gaspar A.M. \& Souto F.J. 2005. Hepatitis E virus antibodies in swine herds of Mato Grosso state, central Brazil. Braz. J. Microbiol. 36:223-226.

Kasorndorkbua C., Guenette D.K., Huang F.F., Thomas P.J., Meng X.J. \& Halbur P.G. 2004. Routes of Transmission of Swine Hepatitis E Virus in Pigs. J. Clin. Microbiol. 41(11):5047-5052.

Khudyakov Y. \& Kamili S. 2011. Serological diagnostics of hepatitis E virus infection. Virus Res. 161:84-92.

Liang H., Su S., Deng S., Gu H., Ji F., Wang L., Liang C., Wang H. \& Zhang G. 2014. The Prevalence of Hepatitis E Virus Infections among Swine, Swine Farmers and the General Population in Guangdong Province, China. PLoS One. 9(2):1-9.

Lopes dos Santos D.R., Lewis-Ximenez L.L., da Silva M.F., de Sousa P.S., Gaspar A.M. \& Pinto M.A. 2010. First report of a human autochthonous hepatitis E virus infection in Brazil. J. Clin. Virol. 47:276-279.

Meng X.J., Purcell R.H., Halbur P.G., Lehman J.R., Webb D.M., Tsareva T.S., Haynes J.S., Thacker B.J. \& Emerson S.U. 1997. A novel virus in swine is closely related to the human hepatitis E virus. Proc. Natl. Acad. Sci. USA. 94:9860-9865.

Meng X.J. 2006. Hepatitis E as a zoonosis. In: Thomas H, Zuckermann A, Lemon S, editors. Viral Hepatitis, 3rd ed. Oxford: Blackwell Publishing Ltd. p.611-623.

Munné M.S., Vladimirsky S., Otegui L., Castro R., Brajterman L., Soto S., Guarnera E., Molina V., Monfellano M., Schlauder G.G. \& González J.E. 2006. Identification of the First Strain of Swine Hepatitis E Virus in South America and Prevalence of Anti-HEV Antibodies in Swine in Argentina. J. Med. Virol. 78:1579-1583.

O’Connor M., Roche S.J. \& Sammin D. 2015. Seroprevalence of Hepatitis E virus infection in the Irish pig population. Ir. Vet. J. 68:8.

Paiva H.H., Tzaneva V., Haddad R. \& Yokosawa J. 2007. Molecular characterization of swine hepatitis E virus from southeastern Brazil. Braz. J. Microbiol. 38:693-698.

Schlosser J., Eiden M., Vina-Rodriguez A., Fast C., Dremsek P., Lange E, Ulrich R.G. \& Groschup M.H. 2014. Natural and experimental hepatitis E virus genotype 3 - infection in European wild boar is transmissible to domestic pigs. Vet. Res. 45:121. 
Sergeant E.S.G. 2015. Epitools epidemiological calculators. AusVet Animal Health Services and Australian Biosecurity Cooperative Research Centre for Emerging Infectious Disease. Available in <http://epitools.ausvet.com.au> Accessed on September 19, 2015.

Smith D.B., Simmonds P.; International Committee on Taxonomy of Viruses Hepeviridae Study Group, Jameel S., Emerson S.U., Harrison T.J., Meng X.J., Okamoto H., Van der Poel W.H. \& Purdy M.A. 2014. Consensus proposals for classification of the family Hepeviridae. J. Gen. Virol. 95:2223-2232.

Tam A.W., Smith M.M., Guerra M.E., Huang C.C., Bradley D.W., Fry K.E. \& Reyes G.R. 1991. Hepatitis E virus (HEV): molecular cloning and sequencing of the fulllength viral genome. Virology. 185:120-131.

ThermoFisher Scientific. 2015. PrioCHECK® HEV Antibody porcine. Available in $<$ http://www.thermofisher.com/order/catalog/product/4600010> Accessed on April 10, 2015.

United States Department of Agriculture (USDA). 2015. PSD: production, supply and distribution online. Livestock, Pork selected countries summary: production, total exports. Washington, DC. Available in <http://apps.fas.usda.gov/psdonline/> Accessed on June 23, 2015.

Vitral C.L., Pinto M.A., Lewis-Ximenez L.L., Khudyakov Y.E., dos Santos D.R. \& Gaspar A.M. 2005. Serological evidence of hepatitis $E$ virus infection in different animal species from the Southeast of Brazil. Mem. Inst. Oswaldo Cruz. 100:2117-2217.

Walachowski S., Dorenlor V., Lefevre J., Lunazzi A., Eono F., Merbah T., Eveno E., Pavio N. \& Rose N. 2014. Risk factors associated with the presence of hepatitis E virus in livers and seroprevalence in slaughter-age pigs: a retrospective study of 90 swine farms in France. Epidemiol. Infect. 142(9):1934-1944.

Yugo D.M. \& Meng X.J. 2013. Hepatitis E Virus: Foodborne, Waterborne and Zoonotic Transmission. Int. J. Environ. Res. Public Health. 10:4507-4533. 
Table 1. Frequency of anti-HEV IgG by gender among pigs of the Federal District, Brazil

\begin{tabular}{|c|c|c|c|c|c|c|}
\hline \multirow[b]{2}{*}{ Gender } & \multicolumn{4}{|c|}{ Anti-HEV IgG } & \multirow[b]{2}{*}{ Total } & \multirow[b]{2}{*}{$(\%)$} \\
\hline & Positive & $(\%)$ & Negative & $(\%)$ & & \\
\hline Male & 98 & 62.8 & 58 & 37.2 & 156 & 34.7 \\
\hline Female & 206 & 70.3 & 87 & 29.7 & 293 & 65.3 \\
\hline Total & 304 & 67.7 & 145 & 32.3 & 449 & 100 \\
\hline
\end{tabular}

Table 2. Frequency of anti-HEV IgG by age classes among pigs of the Federal District, Brazil

\begin{tabular}{ccccccc}
\hline & \multicolumn{9}{c}{ Anti-HEV IgG } & & \\
\cline { 2 - 5 } Age group & Positive & $(\%)$ & Negative & $(\%)$ & Total & $(\%)$ \\
\hline Young & 85 & 69.7 & 37 & 30.3 & 122 & 27.2 \\
Adult & 219 & 67.0 & 108 & 33.0 & 327 & 72.8 \\
Total & 304 & 67.7 & 145 & 32.3 & 449 & 100 \\
\hline
\end{tabular}

Table 3. Prevalence of anti-HEV IgG in swine sera by regions of the Federal District, Brazil

\begin{tabular}{ccccc}
\hline & & & \multicolumn{3}{c}{ Anti-HEV IgG } \\
\cline { 4 - 5 } Localities & Farms & Animals & Positive & Prevalence $(\%)[$ CI =95\%] \\
\hline Brazlândia & 18 & 26 & 16 & $61.5[42.5-77.6]$ \\
Ceilândia & 20 & 38 & 30 & $78.9[63.7-88.9]$ \\
Gama & 22 & 35 & 30 & $85.7[70.6-93.7]$ \\
Paranoá & 29 & 43 & 35 & $81.4[67.4-90.3]$ \\
Planaltina & 85 & 211 & 123 & $58.3[51.6-64.7]$ \\
Recanto das Emas & 2 & 2 & 1 & $50.0[9.5-90.5]$ \\
Riacho Fundo & 3 & 5 & 1 & $20.0[3.6-62.4]$ \\
Samambaia & 20 & 35 & 27 & $77.1[61.0-87.9]$ \\
Santa Maria & 1 & 1 & 0 & $0.0[0.0-79.3]$ \\
São Sebastião & 12 & 20 & 17 & $85.0[64.0-94.8]$ \\
Sobradinho & 16 & 23 & 17 & $73.9[53.5-87.5]$ \\
Taguatinga & 6 & 10 & 7 & $70.0[39.7-89.2]$ \\
Total & 234 & 449 & 304 & $67.7[63.2-71.9]$ \\
\hline
\end{tabular}




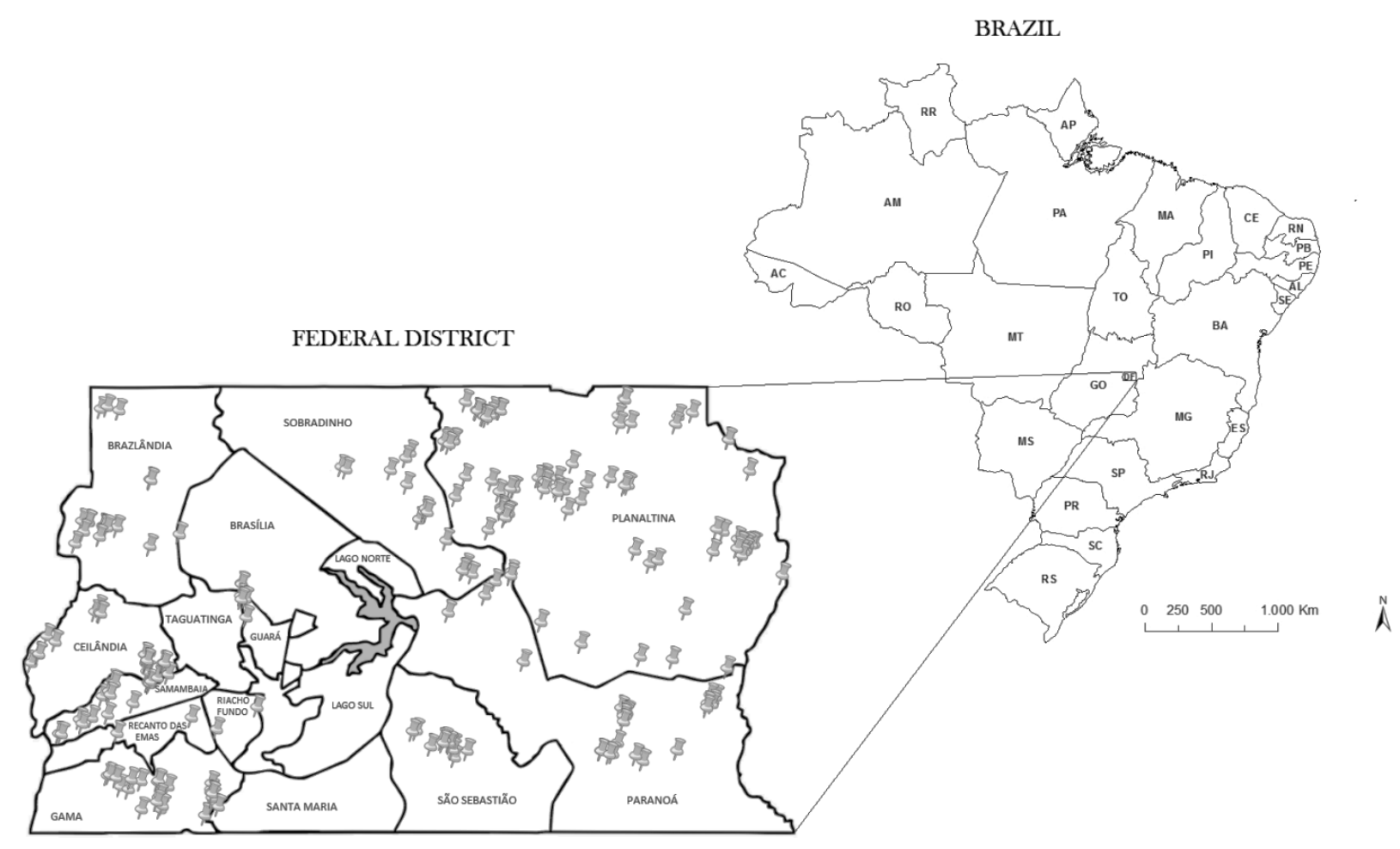

Figure 1. Location of the 234 sampled farms, Federal District, Brazil. 


\section{ANEXO A - FORMULÁRIO DE COLHEITA DE AMOSTRAS}

\section{Sistema de vigilância sanitária na zona livre de peste suína clássica}

\section{Formulário de colheita de amostras - Inquérito por amostragem em CRIATÓRIOS DE SUÍDEOS 2014}

\section{Identificação da propriedade e do proprietário}

\begin{tabular}{|c|c|c|c|c|c|c|}
\hline $1.1 \mathrm{UF}$ & \multicolumn{5}{|l|}{ 1.2 Município } & $\begin{array}{l}1.3 \text { Cód. MAPA } \\
\frac{\text { UF }}{}\end{array}$ \\
\hline \multicolumn{6}{|c|}{ 1.4 Nome do estabelecimento } & 1.5 Código do estabelecimento na UVL \\
\hline \multicolumn{6}{|c|}{ 1.6 Nome do proprietário } & 1.7 Código do proprietário na UVL \\
\hline \multicolumn{5}{|c|}{ 1.8 Coordenadas geográficas } & 1.9 Telefone(s) de contato & \multirow[t]{3}{*}{ 2. Data da colheita das amostras } \\
\hline Grau & \begin{tabular}{l|r} 
Minuto & Segundos \\
\end{tabular} & \multirow{2}{*}{\multicolumn{4}{|c|}{$\begin{array}{l}\text { Minuto } 1 \text { Segundos } \\
\text { Longitude }(\mathrm{W})\end{array}$}} & \\
\hline \multicolumn{2}{|r|}{ Latitude (S) } & & & & & \\
\hline
\end{tabular}

\section{Critério(s) de risco utilizado(s) para seleção do estabelecimento}

\begin{tabular}{|l|l|l|l|l|}
\hline $\begin{array}{l}\text { fronteira internacional ou divisa da zona livre } \\
\text { PSC }\end{array}$ & $\begin{array}{l}\text { fornecimento de resíduos alimentares } \\
\text { (lavagem) aos suídeos }\end{array}$ & $\begin{array}{l}\text { proximidade a reservas naturais, áreas de } \\
\text { proteção ambiental ou parques nacionais } \\
\text { com presença de suídeos silvestres }\end{array}$ & $\begin{array}{l}\text { proprietário com propriedade em outro país } \\
\text { ou em área endêmica }\end{array}$ & proximidade a quarentenários de suídeos \\
\hline assentamentos rurais ou reservas indígenas & proximidade a lixões & proximidade a graxarias & \\
\hline
\end{tabular}

\section{Composição do rebanho no momento da colheita}

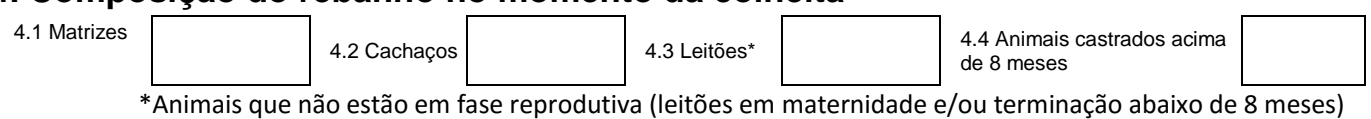

5. Convivência com susceptíveis de outros estabelecimentos?

6. Convivência/contato com susceptíveis selvagens?

\section{Trânsito nos últimos 60 dias}

Cria/Engorda

Abate

\begin{tabular}{|c|c|}
\hline Sim & Não \\
\hline & \\
\hline & \\
\hline
\end{tabular}

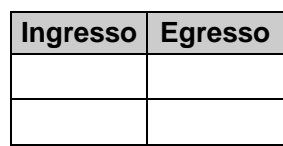

\section{Informações sobre as amostras colhidas}

\begin{tabular}{|c|c|c|c|c|c|c|c|c|c|c|c|}
\hline & Número da amostra & Idade * & Sx & & Número da amostra & Idade * & Sx & & Número da amostra & Idade $^{*}$ & Sx \\
\hline 1 & & & & 11 & & & & 21 & & & \\
\hline 2 & & & & 12 & & & & 22 & & & \\
\hline 4 & & & & 14 & & & & 24 & & & \\
\hline 5 & & & & 15 & & & & 25 & & & \\
\hline 8 & & & & 28 & & & & 28 & & & \\
\hline 9 & & & & 19 & & & & 29 & & & \\
\hline 10 & & & & 20 & & & & 30 & & & \\
\hline
\end{tabular}


9. Resultado da vistoria geral do rebanho e exame clínico dos animais amostrados / Observações:

10. Médico Veterinário responsável pela colheita Nome:

Assinatura:

UVL: N CRMV:

Versão 4.0 - 2014 


\section{ANEXO B - PROTOCOLO DE ELISA PARA DETECÇÃO DE ANTICORPOS ANTI-HEV}

1. MATERIAIS

- Amostras;

- 1 estante para microtubos;

- 5 placas de microtitulação vazias (96 poços);

- 5 placas-teste de microtitulação (96 poços);

- 5 canaletas para soluções;

- 5 erlenmeyers com $270 \mathrm{ml}$ de água destilada estéril;

- 1 pera;

- 25 pipetas de $10 \mathrm{ml}$;

- 1 micropipeta multicanal de 100 a $1000 \mu \mathrm{l}$;

- 1 micropipeta monocanal de 10 a $100 \mu \mathrm{l}$;

- 1 micropipeta monocanal de 100 a $1000 \mu \mathrm{l}$;

- 5 béqueres grandes para descarte;

- 25 racks para ponteira de $200 \mu \mathrm{l}$;

- 5 racks para ponteira de $1000 \mu \mathrm{l}$;

- 5 tubos falcon de $50 \mathrm{ml}$;

- 1 estante para tubos falcon;

- Papel toalha;

- Luvas;

- Estufa a $37^{\circ} \mathrm{C}$;

- Timer;

- Vórtex;

- Álcool 70;

- Pia; e

- Leitora de ELISA.

2. PROCEDIMENTOS

- Seguiu-se o protocolo do Kit de ELISA para detecção de anticorpos suínos antiHEV PrioCHECK® HEV Ab porcine (Prionics AG). 


\section{PrioCHECK ${ }^{\oplus}$ HEV Ab porcine}

ELISA for in vitto detection of antibodies against Hepalits $E$ vinus in serum and meat juice of pigs

5 strip plate kit for 450 samples

"Prionics AG

Version 1.0_e

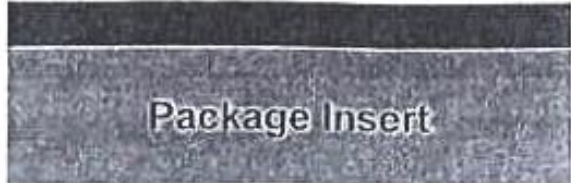

\section{Introduction}

Hopatitis E vinus (HEV) is an emerging pathoget which primarily appears in countries, tike India, Asia, Africa and Central America, causing enterically transmitted hepatitis in human. HEV belongs to the family Hepeviridae and is a nonenveloped, icosahedrat capsid containing a linear single-stranded, positivesense RNA with a length of approx 7200 bases which codes for three open reading frames

In human, acute hepatitis $E$ is a severe illness with a comparable clinical manifestation to hepatitis A. it is usually solf-limiting. During prognancy a fulminant. course of illness develops mote often, accomparued by a high mortabity rate of approx $20 \%$ in moles and non-pregnant fernales, the mortality rate is $0.5 \%-4.0 \%$ No incidence of chronic inflammation of hepatitis $E$ has been reported.

In industrialized countries, HEV infections in humar have long been thought to occur only in travelers to HEV endernic regions. In recent years, however, increasing numbers of sporadic HEV infections in nonendemic regions have been reported that cannot be explained with travelling and increasing avidence points to a transmission from domestic pigs to human.

The PrioCHECK $K^{*}$ HEV Ab porcine is a reliable and tast diagnostic test for detection of antibodies against Hopatitis $E$ virus in porrinn senum and mast lutice samples and can be used for monitoring and survetlance purposes.

\section{Test Principle Inill}

The PrioCHECK ${ }^{\circ}$ HEV Ab porcine for the detection of antibodies directed against Hepatitis E virus in portine serum and meat juice samples is based on ELISA technology.

The PrioCHECK ${ }^{\circ}$ HEV Ab porcine follows a four step protocol, consisting of Sample Preparation, Sample Incubation, Conjugate Incubation and Detection. Recombinant Hepatitis E virus (HEV) antigen of the open reading frame (ORF) ORF 2 and ORF 3 of the genotypes 1 and 3 is coated on the ELISA plate. Serum or meat juice samples are incubated on the plate. A paroxidase (POD) labeled anti-pig antibody is used for the detection of antibodies bound to the recombinant HEV antigens. Color development using TMB substrate measured optically at a wavelenoth of $450 \mathrm{~nm}$ shows the prosence of antibodies directed egainst HEV

One plate with 90 prepared samples can be analyzed within 150 minutes.

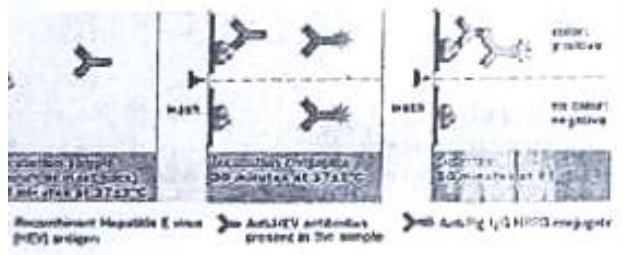

Store kit at $5 \pm 3^{\circ} \mathrm{C}$ untd expiry date. See kit label for actual expiry date. The shelf fife of diluted, opened or reconstitutad components is noted below, where appropriate Chamical hazard data are avatable in section "Safety Regulations and R8S Stotements" (Appendix IV)

\section{Component 1}

Test Plate

(Strip Plate) Five Test Platos ate delivored in vacuum bags containing a desiccant bag

Component 2

Dilution Buffer (Ready to- 450 )

Threa botlles, each containing $60 \mathrm{ml}$ of Dilusion Buffer The Difution Buffer is used to difute the samples and conjugate

Color of solution. blute

\section{Component 3}

Washing Fluid (10x)

( $10 \times$ concentrate, dilute before use)

Four bottles, each containing $60 \mathrm{mi}$ Wastung Fluid

(10x)

Prepare Washing Fluid working solution by muxing 1 part Washing Fluid (10x) with 9 parts demeneralized water or water of equal quality Mix until a clear solution is obtained.

See Append $x$ II

Stabulity of Wash Fluid working solution

4 weeks at $5 \pm 3^{x} \mathrm{C}$

-1 week at $22+3^{\circ} \mathrm{C}$.

Component 4

Conjugate (100x)

(100x concentrate, dilute before use)

One val contains $13 \mathrm{ml}$ Conjugato (100x) Prepare

Conjugate working solution by mixing 1 part of Conjy. gate $(100 x)$ with 99 parts of Dilution tiufier

Dilute the amount of Conjugate necessary to run the test, just prior to use

See Appendix II

\section{Component 5}

Positive Control (Ready-to-use)

One vial contains $750 \mu 1$ Positive Contro

Biack lid

\section{Component 6}

Cut-off Control (Ready-to-use)

One vial contains $750 \mu$ il Cut-off Contral

Grey lid

\section{Component 7}

Negative Control (Ready-to-use)

One vial contains 750 fi Negative Control

White lid

\section{Component 8}

Chromogen (TMB) Substrate (Ready-to-use)

One bottle containing $60 \mathrm{ml}$ Chromogen (TMB) Sub-

strate. The Chromogen (TMB) Substrate is the sub.

strate for the color reaction.

Component 9

Stop Solution (Ready to-uste) Sclution is used to stop the color development

\section{Additional Kit Contents:}

- Package Inser

- Seating flime
One boltle cantaining $60 \mathrm{ml}$ Stop Solution. The Stop
For in-vitro veterinary diagnostic use only Store at $5 \pm 3^{\circ} \mathrm{C}$

Product No 4600010

\section{Additional Material Requirec}

General:

Laboratory equpment according to national safety

regulations

- Dermineralized water or water of equal quality mus be used

- Dummy plate, used for sample dilutoon (e g clear colarless round bottom 96 well plates) or equivalent, non binding

- Single channel pipeltes and multi channel pipettes sutable to pipotte the required volumes

- Pipette tips las recommended by pipette manufacluter)

Solution reservars

- Vortex

Sample preparation:

- Deficaled biod collection tubes

- Dedicaled meat juice collection tubes

Analysis of Results:

Plate Reader, eg. Tecan Sunrise or equivalent The reader has to have an appropriate filter set to read the plates at $450 \mathrm{~nm}$. (Reference $620 \mathrm{~mm}$ )

Optional

Plate washer eg Tecan Hydroflex or equivalent-

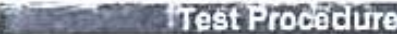

\section{Precautions}

National guidetines for working with animal samples must be strictly foltowed. The PrioCHECK ${ }^{2}$ HEV AL porcine must be performed in laboratones suited far this purpose

Samplas should be considered as potentially infectious and all items which contact the samples as potentially contarninated

Chemical hazard data are availabie in section "Satety Regulations and R\&S Statements" (Appendix IV)

Notes

To achieve optimal results with the PrioCHECK ${ }^{\circ} \mathrm{HEV}$ $\mathrm{Ab}$ porcine, the following aspects must be considered

The test procedure must be strictly followed

- Pipette tips liave to be changed tor every pipetting step

- Separate solution reservoirs must be used for eact reagent

- Kut compononts must not be used after their expiry date or if changos in their appearance ate observed

- Kit components of different kit lot numbers must not be used together

- Demineralized water or equal must be used for the tost

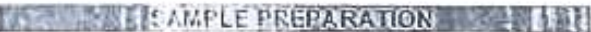

- Serum can be obtaned using standard methods

- If meat juice is tested. a piece of muscle tssue e.g $10 \mathrm{~g}$ is either freeze.thawed in a dedicated device or alternativoly the piecon of meat can be squeezed to obtain mest juice

- Heat inactivated semples may lead to an increased background and ere therefore not recommended to be used 


\section{SAMPLE DILUTION:}

Sample ditution for serum samples

Serum samples are diluted $1: 100$ controls $1: 100$

- Use a Dummy Plate or equivalent for first samplo dilution

- Add $10 \mu \mathrm{l}$ o! Positive Control to welis A1 and B1 of the Dummy Plate

- Add $10 \mu \mathrm{ll}$ of Cut-off Control to wells C1 and Di of the Dummy Plate

- Add $10 \mu \mathrm{l}$ of Negative Control to wells E1 and $F t$ of the Dummy Plate

- Add $10 \mu \mathrm{l}$ of serum samples to the remaining wetls of the Dummy Plate.

- Add $90 \mu$ l of Dilution Buffer to each well of the Dummy Plate and mix by pipetting up and down 5 times

- Add $90 \mu$ of Dilution Buffer to each weil of the Test Plate.

- Transfer $10 \mu \mathrm{for}$ the diluted samples and controls from the Dummy Plate to the Test Plate and mux by pipetting up and down 5 times

Sample dilution for meat juice samples

Meat juice samples are diluted 1:10 controls 1 to0

- Use a Dummy Plate or equivalent for first sample dilution.

- Add $10 \mu$ of Positive Control to wells A1 and B1 of the Dummy Plate

- Add $10 \mu t$ of Cut-Off Control to welis C1 and D1 of the Dummy Plate.

- Add $10 \mu \mathrm{l}$ of Negative Control to wells E1 and $\mathrm{F}_{1}$ of the Dummy Plate

- Add $90 \mu$ of Dilution Buffer to wells containing controls $A 1$ to $F 1$ of the Dummy Plate.

- Add $100 \mu$ l of meat juice samples to the remaining weils of the Dummy Plate

- Provide $90 \mu \mathrm{l}$ of Dilution Buffer to all wells of the Test Plate.

- Transfer $10 \mu \mathrm{l}$ of meat juice samples and diluted controls from the Dummy Plato to the Test Plate and $\mathrm{mx}$ by pipetting up and down 5 times.

\section{EXMBSMESTSAPLETINCUEATION}

- Carefully tape over the Test Plate with an unused sealing film

- Incubate the samples on the Test Plate for $60 \pm 1$ minutes at $37 \pm 3^{\circ} \mathrm{C}$

- Wash the Test Plate four times with $300 \mu l$ Wash Fluid working solution (see Appendix II).

- Tap the plate over a paper towel to remove any residual liquid from the welis

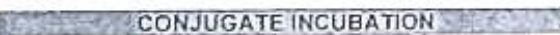

\section{Preparatory Steps}

- Dilute the needed amount of Conjugate $(100 x) 100$ fold in Dilution Buffer (e.g add $100 \mu 1$ Conjugate to $9.9 \mathrm{ml}$ Dilution Buffer for ono full plate; see Appendix II)

Conjugate incubation

- Add $100 \mu \mathrm{l}$ of the diluted Conjugate to each well of the Test Plate.

- Carefully tape over the Test Plate with an unused sealing film

- Incubate the Test Plate for $30 \pm 1$ minutes at $37 \pm 3^{\circ} \mathrm{C}$

- Wash the Test Plate four times with $300 \mu \mathrm{l}$ Wash Fluid working solution (see Appendix II)

- Tap the plate over a paper towel to remove any residual liquid from the wells.

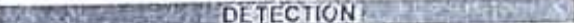

\section{Substrate reaction}

- Add $100 \mu$ of the Chromogen (TMB) Substrate to each well on the Test Plate.

Incubate the Test Plate for $30 \pm 1$ minutes at $22 \pm 3^{\circ} \mathrm{C}$.

- Add $100 \mu \mathrm{l}$ of the Stop Solution to each weil of the Test Plate.

Remark: Add the Stop Solution in the same order end time as the Chromogen (TMB) Substrate solution uvas dispensed
Note: The color of the Positive Controls will chango from blue to yellow.

Detection

Shake tho Test Plate shortly (5-10 s) either on at orbital shaker ( $-300 \mathrm{rpm})$ or manually on the working bench.

- Read the Test Plate in the ELISA reader at $450 \mathrm{~nm}$ within 60 minutes

Recommendation Uso a reference titer at $620 \mathrm{~nm}$

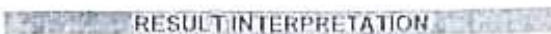

Validation criteria

- The mean $\mathrm{OD}_{450}$ of the Positive Controls minus the $\mathrm{OD}_{4}$ of the Cut-oft Control must be 203

- The mean $\mathrm{OD}_{4}$ of the Cut-off Coritrol munus the $O D_{4}$ of the negative control must be $\geq 0$ as

- The mean $\mathrm{OD}_{4 \times n}$ of the Negative Controls must te $<0.15$

If these critena are not met, the fesults are invalid and the plate has to be retested

Cut-off calculation

The Cut-off is calculated as mean $\mathrm{OD}_{400}$ of the Cut-pth contral multiplied with 12

meanOD $D_{t i w n}$ of Cut-Off Control $+12=c u t-o f$

Interpretation of results

- Results obtained abovo or equal to the cut-oft are considered positive

- Results between the $\mathrm{OD}_{450}$ of the Cut-off Control and the cut-off (see calculotion above) are douttful and it is recommended to retest those sampies it. they remain in the doubtfut are, a second sample taken at a later time point should be taken and taken

- Results cbtained below the cut-ott are negative

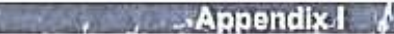

Notice

This manual is believed to be complete and accurate at the time of publieation in no event ghall Prionics AG be liable for incidental at consequential damage in connection with or ansing from the use of this manual

Liability

Pronics AG warrants its products will meet their applicable published specification when used in accordance with their applicable instructuons and within the declared products life time. Prionics AG makes no other warranty. expressed or implied Ther is no warranty of merchantability or fitness for a par. ticular purpose. The wartanty provided herein and the data, specifications and descnptuons of Prionics AG products appearing in Prionics AG published cata logues and product literature may not be altered except by express whtten agreement signed by an officer of Pronics AG Representation, orcl or writien, which are inconsistent with this warranty or such publications are not authorized and if given, should not be relied upon

In the event of a beach of the foregoing warranty. Prionics AGs sole obligation shat be to tepair of replece, at its option, the applicable product or part thereof provided the customer notifies Prionics AG promplly of any such breach If atter exercising rea sonatile efforts, Prionics AG is unable to repair of replace the product or part, then Prionics AG shail refund to the customer all monies paid for such appli. cable product or par

Prionics $A G$ shall not be flable for consequential. incidental, special of any other indirect danuges resulling from economic loss ot property damage sustained by any customer from the use of its prod ucts.

Prionics A.G is an ISO 90012000 certified company

\section{Appendix}

Preparation of Washing Fluid working solution and Conjugate Solution

Washing Fluid working solution

Mixindicated volumes of demineralized water and Marindcaled volumes ol dem proparty to obtain the Washing Fluid (10x) and mix propeny to obtalution desited volume of Wasning Fing fluid $(10 x)$ to a 11

bottle

$000 \mathrm{ml}$ of demineralized water and mix.

\begin{tabular}{|c|c|c|}
\hline $\begin{array}{l}\text { Volume Vhashing Flude } \\
\text { working salution }\end{array}$ & $\begin{array}{l}\text { Ambuat of Wisting } \\
\text { Filuid }(10 \times)\end{array}$ & $\begin{array}{l}\text { Amount demi } \\
\text { Water }\end{array}$ \\
\hline 0,11 & $30 \mathrm{ml}$ & $270 \mathrm{ml}$ \\
\hline 0.51 & $50 \mathrm{ml}$ & $450 \mathrm{ml}$ \\
\hline 1,011 & $100 \mathrm{mt}$ & $920 \mathrm{mil}$ \\
\hline 2,01 & $200 \mathrm{ml}$ & $1400 \mathrm{ml}$ \\
\hline
\end{tabular}

Conjugate working solution

Mix indicated volumes of Conjugate $(100 x)$ with the Mapropite amount of Olution Buffer (supplied with approptlate amoum of Dired arnount of Conjugate

\begin{tabular}{|c|c|c|c|}
\hline $\begin{array}{l}\text { Number } \\
\text { of plates }\end{array}$ & $\begin{array}{l}\text { mil presed } \\
\text { Conjugatia }\end{array}$ & $\begin{array}{l}\text { nit Conjugato } \\
\text { (1tosr) }\end{array}$ & ml Dilution Buffer \\
\hline : & $12 \mathrm{ml}$ & $0,12 \mathrm{ml}$ & $11,33 \mathrm{ml}$ \\
\hline 2 & $24 \mathrm{ml}$ & $0,24 \mathrm{ml}$ & $24,7 \mathrm{~B} \mathrm{~m} l$ \\
\hline ] & $35 \mathrm{mt}$ & $0,36 \mathrm{mt}$ & $15,64 \mathrm{mt}$ \\
\hline 4 & $4 \mathrm{ml}$ & $048 \mathrm{ml}$ & $47,52 \mathrm{mit}$ \\
\hline 5 & $60 \mathrm{mi}$ & $0,60 \mathrm{mt}$ & $59,4 \mathrm{mi}$ \\
\hline
\end{tabular}

\section{Appendix II}

Pipetting Schemes

Recommended pipetting scheme for Dummy Plate and Test Plate

\begin{tabular}{|c|c|c|c|c|c|c|c|c|c|c|c|}
\hline & , & 1 & 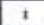 & , & 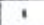 & I & , & I & , & 1 & " \\
\hline & 54 & & & & & 519 & Cois & Est: & Fin & $20:$ & \\
\hline & $5 \pi$ & 57 & 3 & Sins & 83 & 1 avis & nis & H:5] & $\leqslant=$ & $\mathrm{kn}$ & Ist \\
\hline & $\approx$ & 169 & Sसर & 갤 & 135 & Pra & 283 & Find & 73 & Fine & St \\
\hline & 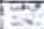 & $E$ & tast & 7 & $\$ 2$ & $\neq$ & 30 & $y-1$ & $E 0$ & $1 \mathrm{EM}$ & \\
\hline$t$ & 5 & & in & 150 & 17 & 79 & 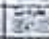 & $8=3$ & $2 E$ & iथी? & {$[2$} \\
\hline$F$ & some & $\rightarrow$ & 38 & $3 x$ & 100 & $\frac{192}{200}$ & $\frac{30}{240}$ & $\sqrt{153}$ & 63 & And & $\overrightarrow{|c|}$ \\
\hline${ }^{\prime}$ & 39 & 9 & 10 & 1280 & 15 & 87 & 60 & 35 & 68 & 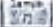 & $\sqrt{11}$ \\
\hline & 22 & दike & 4 & $6 x^{2}$ & 10 & 4 & 30 & $\mu z$ & $\overrightarrow{5 W}$ & ENS & \\
\hline
\end{tabular}

\section{Appeitids:}

Safety Regulations and R\&S Statements

National Safoty Regulations must be strictly tollowed.

\section{R\&S Statements}

\section{Component 1}

Test Plate

The product does not have to be labelled due to the calculation procedure of the "Goneral Classification guideine for preparations of the $\mathrm{EU}^{\prime}$ in the latest valid version.

Component 2

Dilution Buffer (Ready-to-use)

The ptoduct does not have to be labelled due to the calculation procedure of the "General Classification guideline for preparations of the EU' in the latest vatid version.

Component 3

Weshing Fluid (10x)

The product does not have to be labelled due to the calculation procedure of the "Gereral Classification guideline for preparations of the EU" in the latest valid version

Component 4 Sent. Sensivising

Conjugate (100x)

Hazard code Xi Sensitizing

R43. May cause sensitization by skin contact.

S24: Avoid contact with skin

\$37. Wear suitable gloves 
Component 5

Positive Control (Rearisensitising

Hazard code: $X$ i (Rensidy-to-use)

R43: May cause sensitizing

S24: Avoid contact with skin by skin contact

S37: Wear suitabl with skin.

Wuitable gloves.

Component 6 Sas

Cut-off Control (Reati Sensitising

Hazard Control (Ready-to-use)

R43: Code: Xi Sensitizing

S24: Avoid cause sensitization by skin contact.

S37: Wear contact with skin.

S37: Wear suitable gloves,

\section{Component 7}

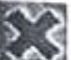

Negative Control $x$; Sensitising

Hazard Control (Ready-to-use)

R43: code: Xi Sensitizing

R43: May cause sensitization by skin contact

S24: Avoid contact with skin.

S37: Wear suitable gloves.

\section{Component 8}

Chromogen (TMB) Substrate (Ready-to-use)

The product does not have to be labelled due to the calculation procedure of the "General Classification guideline for preparations of the EU* in the latest valid version.

Component 9 C corrosive

Stop Solution (Ready-to-use)

Hazard Code: C Corrosive

R34: Causes burns.

S26: In case of contact with eyes, rinse inmediately with plenty of water and seek medical advice.

S36/37/39: Wear suitable protective clothing, gloves and eye/face protection.

S45: In case of accident or if you feel unwell, seek medical advice immediately (show the label where possible).

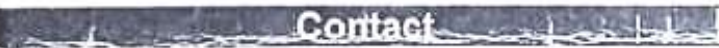

\section{Produced by:}

\section{MIKROGEN GmbH}

Floriansbogen 2-4

82061 Neuried

Germany

\section{Produced for:}

Prionics AG

Wagistrasse 27a

$\mathrm{CH}-8952$ Schlieren-Zurich

Switzerland

Tel. +41442002000

Fax +41442002010

www.prionics.com

info@prionics.com

For our distribution network, please refer to www.prionics.com 


\section{ANEXO C - PRODUÇÕES TÉCNICAS}

\begin{tabular}{|l|l|c|c|}
\hline \multicolumn{4}{|c|}{ PROCEDIMENTO OPERACIONAL PADRÃO } \\
\hline \multirow{2}{*}{$\begin{array}{l}\text { UnB } \\
\text { Universidade de Brasília } \\
\text { Hospital Veterinário } \\
\text { Laboratório de Microbiologia Médica Veterinária }\end{array}$} & $\begin{array}{c}\text { Aprovado em } \\
00 / 00 / 2016\end{array}$ & $\begin{array}{c}\text { Página } \\
\mathbf{1} \text { de } \mathbf{5}\end{array}$ \\
\hline Título: Funcionamento da Leitora de ELISA & \\
\hline
\end{tabular}

\section{Tarefa}

Operar corretamente a leitora de ELISA modelo TP-Reader da marca Thermo Plate.

\section{Local de execução}

Laboratório de Microbiologia Médica Veterinária.

\section{Executante}

Professores, técnicos, residentes e estudantes de graduação e pós-graduação.

\section{Resultados esperados}

São esperadas a padronização e minimização de desvios na execução de tarefas fundamentais para a qualidade do exame, independente de quem as faça aumentando a previsibilidade de seus resultados, minimizando as variações causadas por imperícia e adaptações aleatórias da metodologia, independente de falta, ausência parcial ou férias de um funcionário.

\section{Material necessário}

- Leitora de ELISA TP-Reader Thermo Plate;

- Caneta para o painel de controle;

- Placa de ELISA a ser testada;

- Luvas de látex; e

- Recipiente para descarte da placa de ELISA. 
PROCEDIMENTO OPERACIONAL PADRÃO

\begin{tabular}{|c|c|c|c|}
\hline \multirow{2}{*}{ Mins } & \multirow{2}{*}{$\begin{array}{l}\text { Universidade de Brasília } \\
\text { Hospital Veterinário } \\
\text { Laboratório de Microbiologia Médica Veterinária }\end{array}$} & POP-000 & Revisãc \\
\hline & & $\begin{array}{c}\text { Aprovado em } \\
00 / 00 / 2016\end{array}$ & $\begin{array}{l}\text { Página } \\
2 \text { de } 5\end{array}$ \\
\hline
\end{tabular}

\section{Atividades}

Rodando o ensaio:

1. Ligue o aparelho através do interruptor de energia localizado em sua parte traseira e aguarde em torno de 10 segundos até que a tela inicial seja exibida:

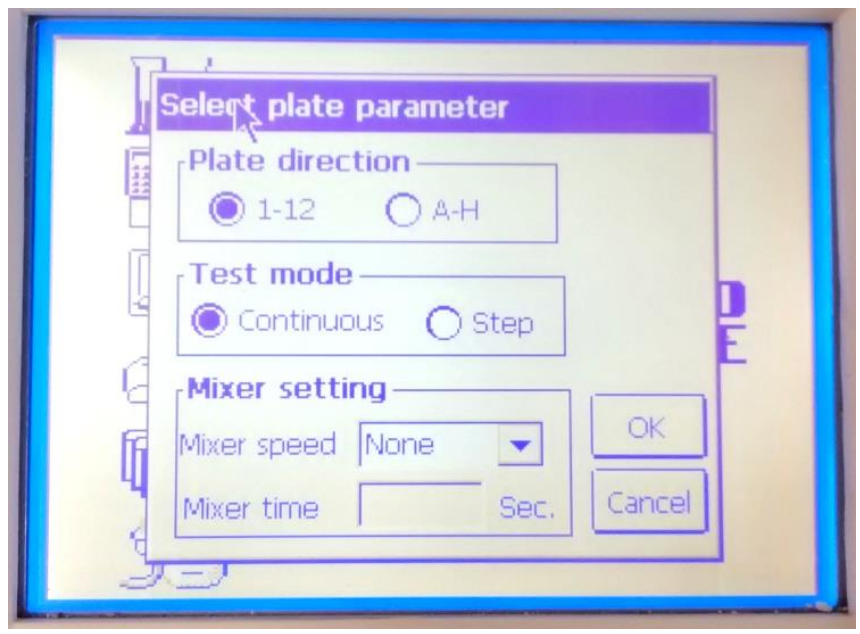

2. Pressione o ícone "Test" com a caneta própria do equipamento;

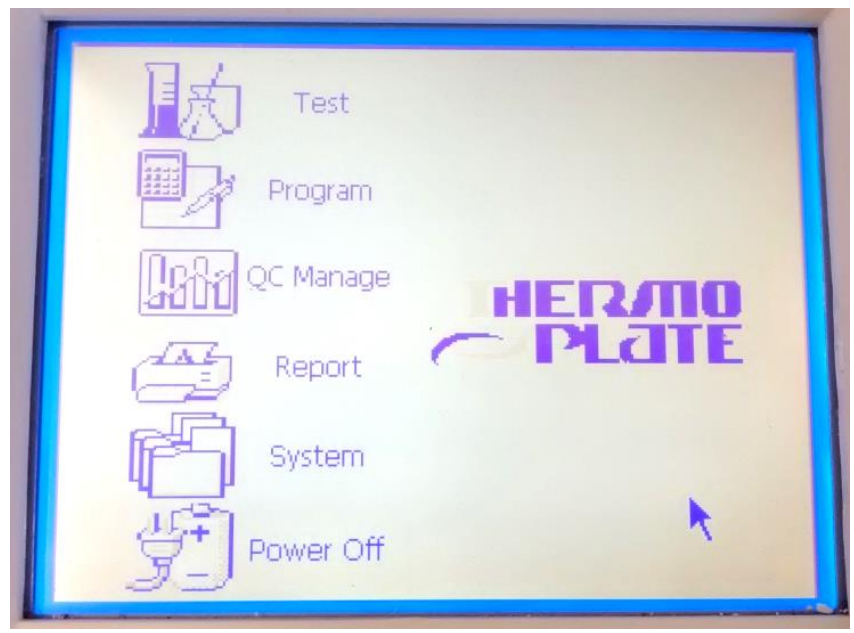

\begin{tabular}{|l|l|}
\hline $\begin{array}{l}\text { Elaborado por: } \\
\text { Luciana F. L. S. Vilanova }\end{array}$ & Revisado por: \\
\hline Data: $11 / 08 / 2015$ & Revisão: \\
\hline
\end{tabular}




\begin{tabular}{|c|c|c|c|}
\hline \multicolumn{4}{|c|}{ PROCEDIMENTO OPERACIONAL PADRÃO } \\
\hline $\mathrm{nB}$ & \multirow{2}{*}{$\begin{array}{l}\text { Universidade de Brasília } \\
\text { Hospital Veterinário } \\
\text { Laboratório de Microbiologia Médica Veterinária }\end{array}$} & POP-000 & $\begin{array}{l}\text { Revisão } \\
00\end{array}$ \\
\hline $\begin{array}{l}\text { MVicro } \\
\text { Micedica } \\
\text { viet }\end{array}$ & & $\begin{array}{c}\text { Aprovado em } \\
00 / 00 / 2016\end{array}$ & $\begin{array}{l}\text { Página } \\
3 \text { de } 5\end{array}$ \\
\hline
\end{tabular}

3. Selecione a direção da leitura da placa ("plate direction") e o modo de teste ("test mode");

4. Se o protocolo do seu kit de ELISA exigir, selecione a velocidade do agitador ("mixer speed") e o tempo do agitador ("mixer time").

5. Pressione "Ok" e vá para a próxima tela:

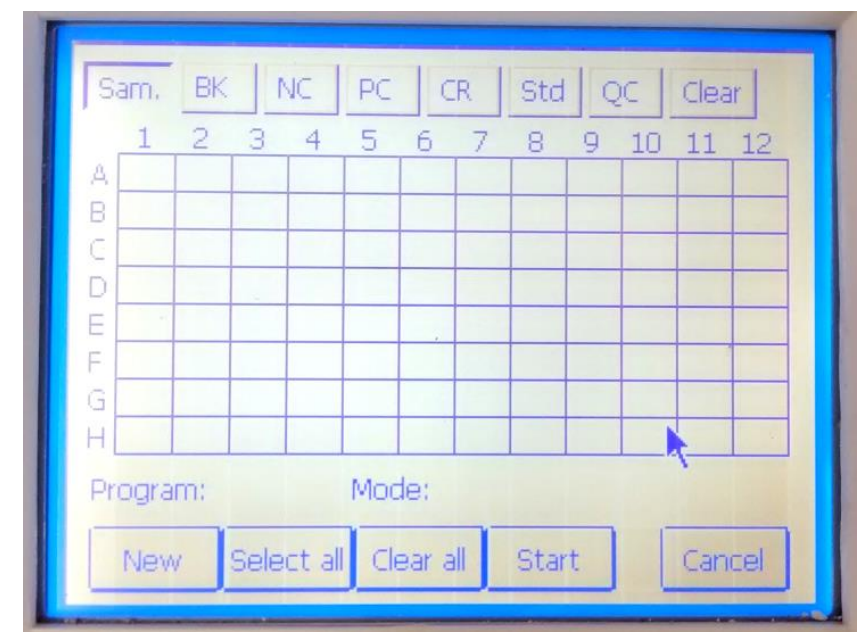

6. Pressione o botão "New", selecione o programa a ser utilizado (POP - 000) e aperte "Ok";

7. Se o programa permitir, ajuste a função de cada poço: selecione a função de poço e clique no poço que você irá marcar;

\begin{tabular}{|c|c|}
\hline \multicolumn{2}{|c|}{ Funções de poço } \\
\hline Amostra ("sample") & 1 a 999 \\
\hline Branco ("blank") & B \\
\hline Controles negativos ("negative controls") & NC \\
\hline Controles positivos ("positive controls") & PC \\
\hline Padrão ("standard") & S1 a S8 \\
\hline Controle de qualidade ("quality control") & QC \\
\hline
\end{tabular}

Elaborado por:

Luciana F. L. S. Vilanova 


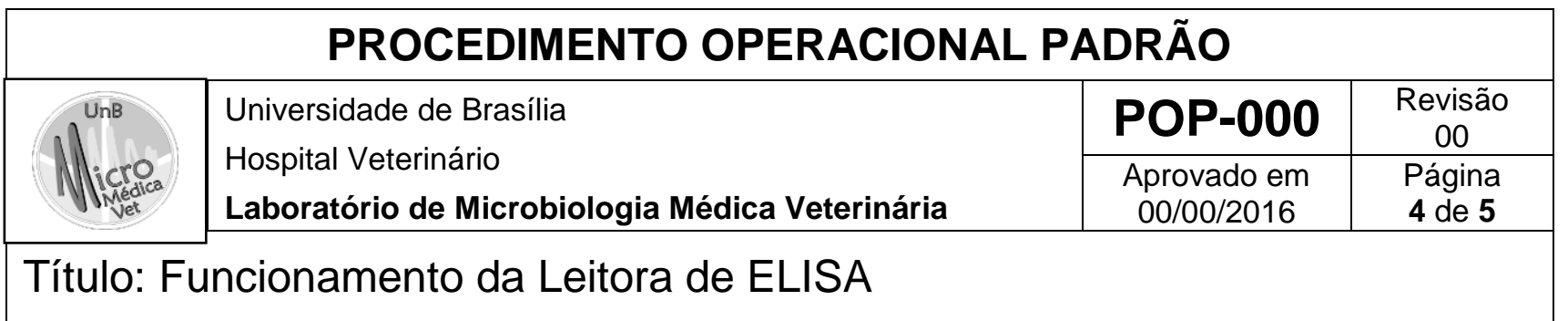

8. Se você desejar apagar poços marcados pressione o botão "Clear" e então selecione o poço que deseja. Se desejar apagar todos os poços pressione o botão "Clear all".

9. Se você desejar selecionar todos os poços pressione o botão "Select all" e aperte "Ok". Nessa opção você também pode selecionar quantos poços quiser de uma só vez.

10. Quando tudo estiver determinado, encaixe com cuidado a placa de ELISA a ser testada na abertura lateral direita do equipamento, feche a tampa e pressione o botão "Start" para realizar o ensaio da placa;

11. Os resultados das colunas 1 a 6 serão exibidos; pressione o botão "7-12>>" para mostrar os resultados das colunas 7 a 12 ;

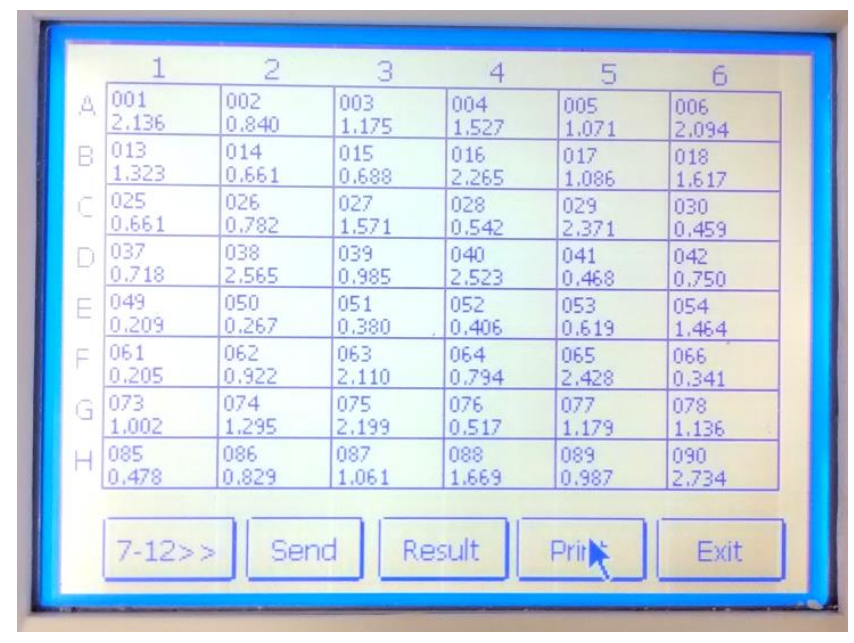

12. Pressione o botão "Result" se quiser exibir os resultados de calibração;

13. Pressione o botão "Print" para imprimir todos os resultados do teste ou o botão "Exit" e "Cancel" para que apenas os dados sejam armazenados.

\begin{tabular}{|l|l|}
\hline $\begin{array}{l}\text { Elaborado por: } \\
\text { Luciana F. L. S. Vilanova }\end{array}$ & Revisado por: \\
\hline Data: $11 / 08 / 2015$ & Revisão: \\
\hline
\end{tabular}




\begin{tabular}{|c|c|c|c|}
\hline \multicolumn{4}{|c|}{ PROCEDIMENTO OPERACIONAL PADRÃO } \\
\hline $\mathrm{nB}$ & \multirow{2}{*}{$\begin{array}{l}\text { Universidade de Brasília } \\
\text { Hospital Veterinário } \\
\text { Laboratório de Microbiologia Médica Veterinária }\end{array}$} & POP-000 & $\begin{array}{l}\text { Revisão } \\
00\end{array}$ \\
\hline $\begin{array}{l}\text { MVicro } \\
\text { Micedica } \\
\text { viet }\end{array}$ & & $\begin{array}{c}\text { Aprovado em } \\
00 / 00 / 2016\end{array}$ & $\begin{array}{l}\text { Página } \\
5 \text { de } 5\end{array}$ \\
\hline
\end{tabular}

14. Se os resultados estiverem dentro do esperado, retire a placa de ELISA testada de dentro do aparelho e descarte de forma apropriada.

15. Para desligar o aparelho clique em "Turn-off". Quando o equipamento avisar na tela, desligue o interruptor de energia.

\section{Cuidados especiais}

- Ao ligar o aparelho uma mensagem de erro poderá aparecer no display se ele não passar pela auto-verificação. Desligue e ligue novamente.

- Você pode testar vários programas em uma placa, ajustando os programas um a um. A leitora suporta até 12 programas em uma placa.

\section{Ações em caso de não conformidade}

Consulte o manual ou peça ajuda a alguém que possua mais experiência com o equipamento.

\section{Bibliografia utilizada}

THERMO PLATE. Manual de Operação TP - Reader. 


\begin{tabular}{|l|l|c|c|}
\hline \multicolumn{4}{|c|}{ PROCEDIMENTO OPERACIONAL PADRÃO } \\
\hline \multirow{2}{*}{$\begin{array}{l}\text { UnB } \\
\text { Universidade de Brasília } \\
\text { Hospital Veterinário } \\
\text { Labolica } \\
\text { Let }\end{array}$} & $\begin{array}{l}\text { POP-000 } \\
\text { Levisão de Microbiologia Médica Veterinária } \\
00\end{array}$ \\
\hline Título: Realização do método de ELISA indireto & $\begin{array}{c}\text { Aprovado em } \\
00 / 00 / 2016\end{array}$ & $\begin{array}{c}\text { Página } \\
\mathbf{1} \text { de } \mathbf{6}\end{array}$ \\
\hline
\end{tabular}

\section{Tarefa}

Detectar anticorpos específicos presentes em soro sanguíneo pelo método de ELISA (ensaio imunoenzimático) para fins de diagnóstico.

\section{Local de execução}

Laboratório de Microbiologia Médica Veterinária.

\section{Executante}

Professores, técnicos, residentes, estudantes de graduação e pós-graduação.

\section{Resultados esperados}

São esperadas a padronização e minimização de desvios na execução de tarefas fundamentais para a qualidade do exame, independente de quem as faça aumentando a previsibilidade de seus resultados, minimizando as variações causadas por imperícia e adaptações aleatórias da metodologia, independente de falta, ausência parcial ou férias de um funcionário.

\section{Princípios do teste}

O teste de ELISA (enzyme-linked immunosorbent assay) baseia-se em reações antígeno-anticorpo detectáveis por meio de reações enzimáticas. Existem diversas variações de ELISA, mas a versão mais comumente utilizada é o ensaio "em sanduíche". Nesse tipo de ensaio, quando se quer detectar anticorpos (ELISA indireto), acrescenta-se a amostra a ser testada em poços de placas de microtitulação previamente cobertos pelo antígeno específico ao qual o anticorpo, se presente, irá se ligar. Os anticorpos que não se ligaram são então removidos por meio de uma lavagem.

\begin{tabular}{|l|l|}
\hline $\begin{array}{l}\text { Elaborado por: } \\
\text { Luciana F. L. S. Vilanova }\end{array}$ & Revisado por: \\
\hline Data: $11 / 08 / 2015$ & Revisão: \\
\hline
\end{tabular}




\begin{tabular}{|c|c|c|c|}
\hline \multicolumn{4}{|c|}{ PROCEDIMENTO OPERACIONAL PADRÃO } \\
\hline & \multirow{2}{*}{$\begin{array}{l}\text { Universidade de Brasília } \\
\text { Hospital Veterinário } \\
\text { Laboratório de Microbiologia Médica Veterinária } \\
\end{array}$} & POP-000 & $\begin{array}{c}\text { Revisão } \\
00\end{array}$ \\
\hline 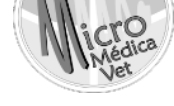 & & $\begin{array}{c}\text { Aprovado em } \\
00 / 00 / 2016 \\
\end{array}$ & $\begin{array}{l}\text { Página } \\
2 \text { de } 6 \\
\end{array}$ \\
\hline \multicolumn{4}{|c|}{ Título: Realização do método de ELISA indireto } \\
\hline
\end{tabular}

Em seguida, acrescenta-se o conjugado, um segundo anticorpo acoplado a uma enzima que irá se ligar somente onde houver a ligação antígeno-anticorpo estabelecida na etapa anterior, funcionando como um anti-anticorpo. $O$ excesso de conjugado também é retirado após outro processo de lavagem. A detecção dessa reação ocorre por meio da adição de um cromógeno, que é o substrato necessário para que ocorra uma reação colorida. Por fim, após certo período, adiciona-se uma solução de parada a fim de interromper a ação da enzima para que a solução não fique com uma cor muito forte $\mathrm{e}$ atrapalhe a leitura do teste. A intensidade da cor desenvolvida é proporcional à quantidade de anticorpos específicos para aquele antígeno presente no soro. Essa intensidade pode ser medida por uma leitora de ELISA por espectrofotometria. Em seguida, deve-se realizar a interpretação desses resultados de acordo com o protocolo específico do teste que está sendo utilizado.

\section{Material necessário}

- Kit de diagnóstico a ser utilizado;

- Estante com as amostras a serem testadas;

- Placas de ELISA "virgens" para diluição das amostras (se necessário);

- Reservatórios para soluções;

- Papel alumínio;

- Erlenmeyers com água destilada estéril;

- Pera;

- Pipetas estéreis;

- Micropipetas mono e multicanal;

- Béqueres para descarte de ponteiras; 


\begin{tabular}{|c|c|c|c|}
\hline \multicolumn{4}{|c|}{ PROCEDIMENTO OPERACIONAL PADRÃO } \\
\hline & \multirow{2}{*}{$\begin{array}{l}\text { Universidade de Brasília } \\
\text { Hospital Veterinário } \\
\text { Laboratório de Microbiologia Médica Veterinária }\end{array}$} & POP-000 & Revisão \\
\hline 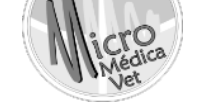 & & $\begin{array}{c}\text { Aprovado em } \\
00 / 00 / 2016\end{array}$ & $\begin{array}{l}\text { Página } \\
3 \text { de } 6\end{array}$ \\
\hline
\end{tabular}

- Racks de ponteiras;

- Tubos falcon;

- Estante para tubos falcon;

- Papel toalha;

- Álcool 70ㅜㅜㅇ

- Luvas de látex;

- Estufa a $37^{\circ} \mathrm{C}$ (ou outras temperaturas);

- Leitora de ELISA;

- Capela de fluxo laminar com UV;

- Timer;

- Vórtex;

- Pia;

- Caneta e papel.

\section{Atividades}

Preparação do material na semana anterior:

1. Utilize o protocolo do seu kit de diagnóstico para calcular a quantidade total necessária de:

- Placas de ELISA "virgens" (quando necessário);

- Reservatórios para soluções;

- Erlenmeyers com água destilada e sua quantidade;

- Pipetas estéreis e seus volumes;

- Micropipetas mono e multicanal e seus volumes;

- Ponteiras e seus volumes;

- Racks para as ponteiras;

- Tubos falcon e seus volumes; 


\begin{tabular}{|c|c|c|c|}
\hline \multicolumn{4}{|c|}{ PROCEDIMENTO OPERACIONAL PADRÃO } \\
\hline & \multirow{2}{*}{$\begin{array}{l}\text { Universidade de Brasília } \\
\text { Hospital Veterinário } \\
\text { Laboratório de Microbiologia Médica Veterinária }\end{array}$} & POP-000 & $\begin{array}{l}\text { Revisão } \\
00\end{array}$ \\
\hline 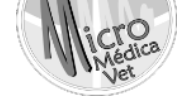 & & $\begin{array}{c}\text { Aprovado em } \\
00 / 00 / 2016\end{array}$ & $\begin{array}{l}\text { Página } \\
4 \text { de } 6\end{array}$ \\
\hline & de $E$ & & \\
\hline
\end{tabular}

2. Após separar todo o material, esterilize tudo o que for possível. Preparação do material no dia:

1. Coloque todo o material que será utilizado naquele dia em cima de uma bancada limpa com álcool $70^{\circ}$.

Obs.: Os materiais que devem ser mantidos à temperatura de geladeira devem ser retirados somente no exato momento de sua utilização;

2. Retire as amostras de soro do congelador e deixe descongelar à temperatura ambiente;

Obs.: Antes de utilizá-las homogenize-as no vortex.

3. Enquanto isso recorte o papel alumínio em tamanho suficiente para cobrir um coxinho e coloque os papéis e os cochinhos que irá utilizar virados para cima na capela de fluxo laminar sob luz UV durante 30 minutos;

4. Após os 30 minutos cubra os coxinhos com os papéis alumínio e leve para a bancada de trabalho;

5. Para não se perder, em uma folha de papel, anote a identificação de cada poço da placa que será testada de acordo com o protocolo do seu teste. Exemplo:

\begin{tabular}{|c|c|c|c|c|c|c|c|c|c|c|c|c|}
\hline & 1 & 2 & 3 & 4 & 5 & 6 & 7 & 8 & 9 & 10 & 11 & 12 \\
\hline A & CP & A005 & & & & & & & & & & \\
\hline B & CP & A006 & & & & & & & & & & \\
\hline C & CN & A007 & & & & & & & & & & \\
\hline D & CN &. & & & & & & & & & & \\
\hline E & A001 &. & & & & & & & & & & \\
\hline F & A002 &. & & & & & & & & & & \\
\hline G & A003 & & & & & & & & & & & \\
\hline H & A004 & & & & & & & & & & & \\
\hline
\end{tabular}




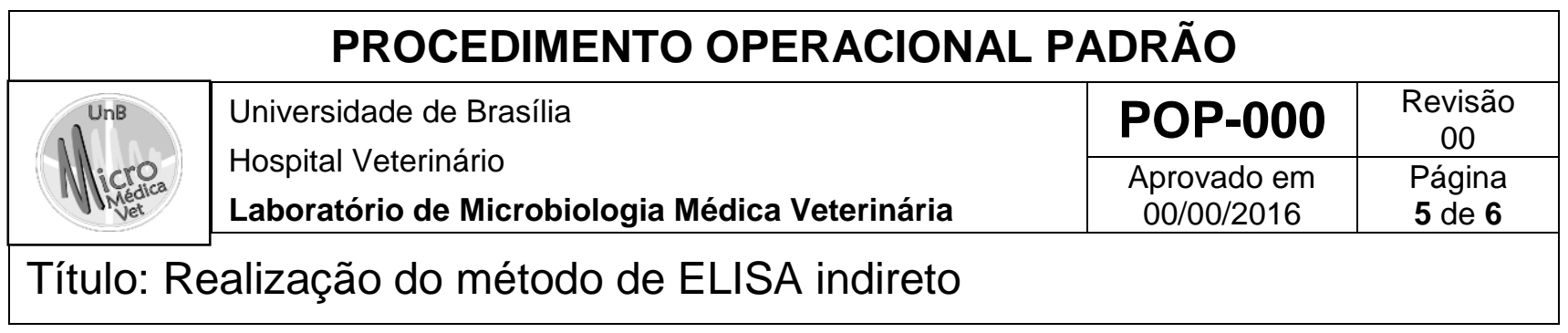

CP: Controle Positivo

$\mathrm{CN}$ : Controle Negativo

A: Amostra

Realização do teste:

1. Siga os passos do protocolo do kit de diagnóstico que está sendo utilizado.

2. Para realizar a leitura da placa de ELISA verifique o POP-000.

\section{Cuidados especiais}

- Se houver um controle positivo tome sempre cuidado para não contaminar outros poços com ele.

- Para não se confundir na hora da pipetagem, mantenha sempre uma mesma ordem utilizando o rack de ponteiras como auxílio.

Obs.: os racks de ponteiras P10 e P200 possuem a mesma configuração de uma placa de ELISA, contendo também 96 ponteiras equivalentes aos 96 poços.

- Sempre que for possível utilize micropipeta multicanal para facilitar os procedimentos.

- Fique atento às restrições de trabalho com algumas soluções. Elas podem ser corrosivas, irritantes, tóxicas. Utilize sempre EPI.

\section{Ações em caso de não conformidade}

Consulte o manual do kit de diagnóstico que está sendo utilizado ou peça ajuda a alguém que possua mais experiência com o método. 
PROCEDIMENTO OPERACIONAL PADRÃO

\begin{tabular}{|l|c|c|}
\hline Universidade de Brasília & POP-000 & $\begin{array}{c}\text { Revisão } \\
00\end{array}$ \\
\cline { 2 - 3 } Hospital Veterinário & Aprovado em & $\begin{array}{c}\text { Página } \\
\mathbf{6} \text { de } \mathbf{6}\end{array}$ \\
\hline
\end{tabular}

Título: Realização do método de ELISA indireto

\section{Bibliografia utilizada}

Acervo pessoal.

Abbas, A. K.; Lichtman, A. H.; Pillai, S. Imunologia Celular e Molecular. 6 ed. Rio de Janeiro: Elsevier, 2008.

Manual de procedimentos PrioCHECK ${ }^{\circledR} \mathrm{HEV}$ Ab porcine (Prionics AG). 